Historic, archived document

Do not assume content reflects current scientific knowledge, policies, or practices. 

Forest Service

intermountain

Research Station

Research Paper

INT-467

August 1993

\section{Establishment With the \\ Prognosis Model}

Dennis E. Ferguson

Clinton E. Carlson

$S L O \cdot \operatorname{COS}(A S P)$

Height $=\exp \left(B_{i} X_{i}\right)$

$x \sim N\left(\mu, \sigma^{2}\right)$

$P(S)=\frac{1}{1+\exp -\left[B_{i} x_{i}\right]}$

Stocking $=[P(S) \cdot T P P \cdot 300] / N$

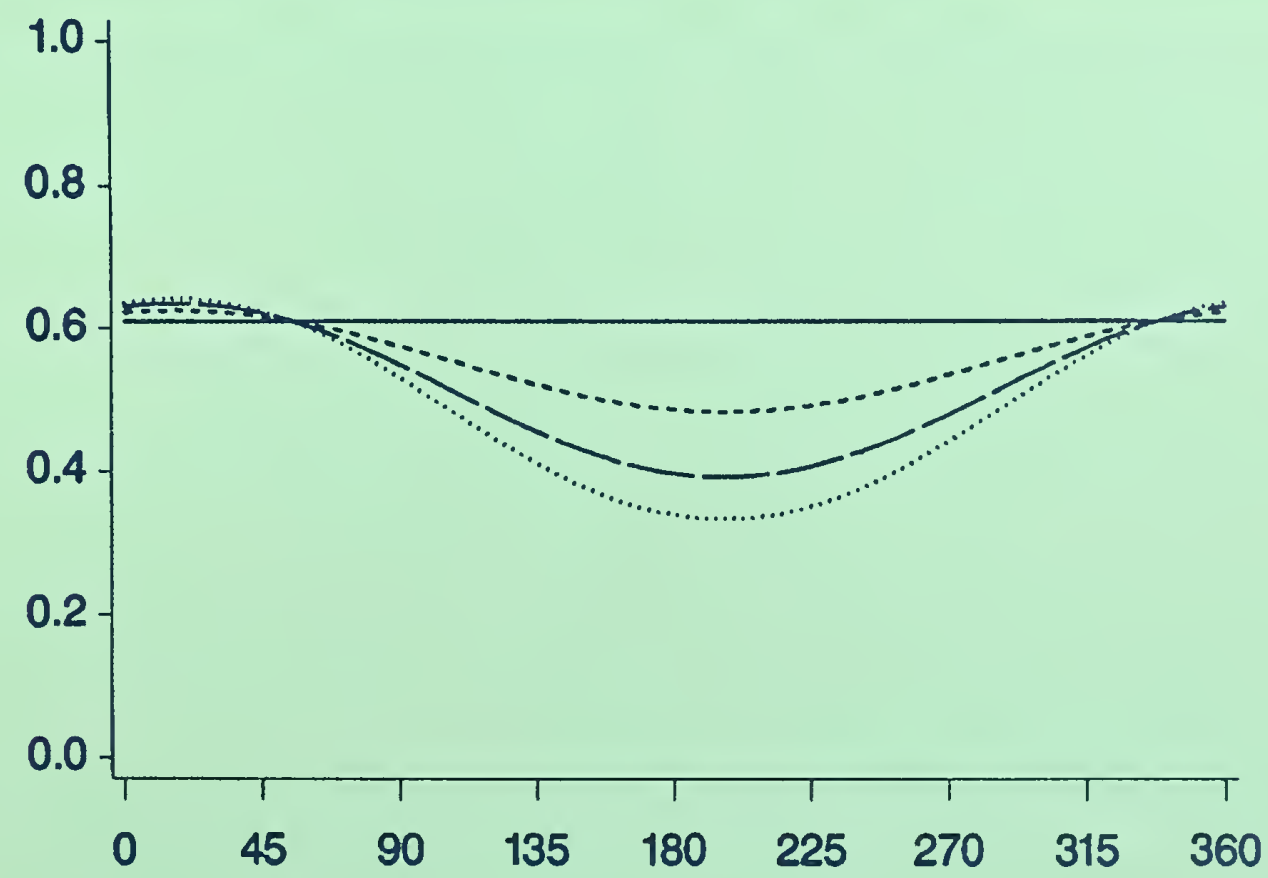




\section{THE AUTHORS}

DENNIS E. FERGUSON is a research forester in the research work unit investigating the silviculture and genetics of Rocky Mountain conifers at the Intermountain Research Station's Forestry Sciences Laboratory in Moscow, ID. He received a Ph.D. degree in forest resources from the University of Idaho in 1991. He has worked primarily with modeling regeneration establishment and growth of young trees and stands.

CLINTON E. CARLSON is a research forester in the research work unit investigating the silviculture of subalpine forest ecosystems at the Intermountain Research Station's Forestry Sciences Laboratory in Missoula, MT. He received a Ph.D. degree from the University of Montana in 1978. His studies have focused on the effects of western spruce budworm on regeneration, growth, and development of Northern Rocky Mountain forests. His current studies focus on relationships among forest structure and composition, forest health, and fire.

\section{RESEARCH SUMMARY}

Data on regeneration of 10 conifer species commonly found in the Northern Rocky Mountains of the Western United States were collected by stratified random sampling of $12,1281 / 300$-acre plots in 537 stands. These data were collected in Montana, central ldaho, and northern Idaho, representing five habitat type series having various combinations of regeneration harvest methods and site preparations. Also included is the influence of western spruce budworm (Choristoneura occidentalis) on regeneration success. The resulting Regeneration Establishment Model is a part of the Prognosis Model. Together, these models can be used to predict growth and yield for even-age and uneven-age management systems. The regeneration model predicts the probability of stocking, seedling density, species composition, and seedling heights 2 to 20 years after harvest for various combinations of regeneration methods, site preparations, habitat types, and budworm defoliation histories.

\section{ACKNOWLEDGMENTS}

Work reported in this publication was partially funded by the Canada/U.S. Spruce Budworms Program (CANUSA). We thank Albert R. Stage, William R. Wykoff, David A. Hamilton, Jr., and Nicholas L. Crookston for their ideas, encouragement, and many hours of consultation that led to this model. Thanks to Ward W. McCaughey for his time and devotion to field sampling in Montana.

\section{CONTENTS}

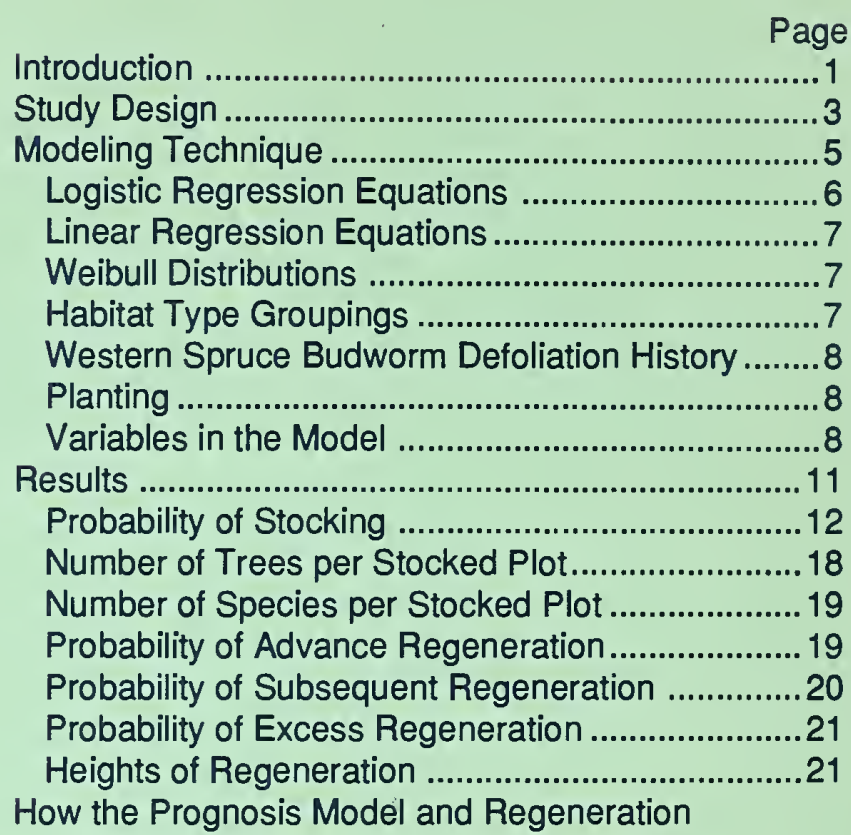

Model Interact ....................................................23

Steps in the Regeneration Model ............................ 24

Step 1: Initiate Regeneration Model.....................24

Step 2: Determine Plot Site Preparation ..............24

Step 3: Compute Years Since Last

Disturbance ...................................................26

Step 4: Calculate the Increment in Stocking ..... 26

Step 5: Estimate Number of Trees ........................26

Step 6: Predict Number of Species .....................27

Step 7: Calculate Probability of Species

Occurrence .......................................................27

Step 8: Estimate Heights ....................................27

Step 9: Add Planted Trees ...................................27

Step 10: Identify Best Trees...................................28

Step 11: Accumulate Stand Statistics ....................28

Step 12: Pass Tree Records ................................ 28

Step 13: Print Regeneration Summary ................. 28

Model Behavior .......................................................29

Example Projection .............................................29

Comparison of Habitat Types ...............................229

Example of Spruce Budworm Effects ....................31

Other Model Features .............................................. 33

Calibration ................................................................33

Consistency of Predictions......................................34

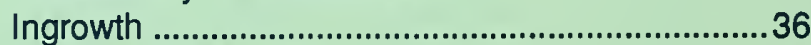

Automatic Tallies ................................................ 36

Site Preparation ....................................................37

Regeneration Model Variants ............................. 37

Regeneration Sprouts ........................................37

Discussion ................................................................ 37

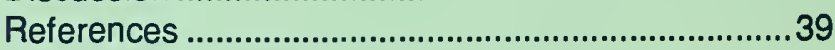

Appendix A: Habitat Type Groupings .......................44 41

Appendix B: Coefficients for Equations. .................. 44 


\title{
Predicting Regeneration Establishment With the Prognosis Model
}

\author{
Dennis E. Ferguson \\ Clinton E. Carlson
}

\section{INTRODUCTION}

Forests of Idaho and Montana are quite diverse. Environmental conditions support forest types ranging from dry ponderosa pine (Pinus ponderosa) forests, to near-rain forests dominated by western redcedar (Thuja plicata) and western hemlock (Tsuga heterophylla), to high-elevation subalpine fir (Abies lasiocarpa) and whitebark pine (Pinus albicaulis) forests where the growing season is short. These forests are highly valued for timber, wildlife, water, grazing, recreation, biological diversity, and esthetics.

Management often involves the manipulation of conifers through timber harvests, natural and artificial regeneration, site preparation, weedings, and thinnings; control of competing vegetation such as shrubs, forbs, and grasses; and control of insects, diseases, and wildfires. Manipulation of forests changes the course of secondary succession which, in turn, affects the future of these ecosystems.

Land managers need to know how their actions affect the course of secondary succession. One particularly important effect is the regeneration of conifers following timber harvest. Can cutover areas be regenerated in a timely manner to desirable species having acceptable growth rates? Which of several alternative silvicultural prescriptions should be used to reach desired future conditions?

Land managers compare alternative silvicultural prescriptions to determine which one best meets management objectives. These comparisons need to be quantified in a biologically meaningful and statistically sound manner. Fortunately, the necessary information is available to quantify the regeneration process in much of the Western United States.

The first requirement for predicting regeneration success is an understanding of the silvical characteristics of conifer species. Many research reports deal with silvics of conifers found in the interior Western United States. For example, Haig and others (1941) summarize many years of research in northern Idaho that provides information on silvical characteristics of conifers and the effects of silvicultural treatments on regeneration success. Many other studies are also available; a good place to begin is Burns and Honkala (1990).

The second requirement for predicting regeneration success is an ecological land classification system. The habitat type system, first developed by Daubenmire (1952), provides the framework for modeling secondary succession. Today, more detailed habitat type classifications are available for Montana (Pfister and others 1977), central Idaho (Steele and others 1981), and northern Idaho (Cooper and others 1991).

The third requirement is a large number of managed stands that can be sampled to represent independent variables in a regeneration model-number of years since disturbance, site preparation, residual overstory density and 
species composition, habitat type, and so on. The Northern Region (Region 1) and Intermountain Region (Region 4) of the Forest Service, U.S. Department of Agriculture, have a large number of managed stands that can be retrospectively examined because there are adequate historical records. Additional stands with adequate historical records are available from other major ownerships, such as Potlatch Corporation, Idaho Department of Lands, Montana Department of Forestry, Champion Corporation, or the Bureau of Indian Affairs and Bureau of Land Management in the U.S. Department of the Interior.

These three factors enabled a retrospective examination of regeneration success in cutover stands and the development of a quantitative regeneration model. The Regeneration Establishment Model described in this paper is a part of the Prognosis Model (Stage 1973; Wykoff and others 1982). The Regeneration Establishment Model predicts establishment of new trees that are added to the inventory of trees being projected by the Prognosis Model. The Prognosis Model implements user-specified management prescriptions and predicts accretion and mortality for the stand. The Prognosis Model with the Regeneration Establishment Model can be useful to managers in the following situations:

1. To decide which of several prescriptions best meets reforestation objectives.

2. To link regeneration to predictions of long-term growth and yield.

3. To predict regeneration in long-term projections of succession or unevenage management.

4. To help develop harvesting schedules.

5. To help in other areas of forest planning where regeneration is important for watershed, wildlife, esthetics, and so on.

Version 1 of the Regeneration Establishment Model was developed for the grand fir-cedar-hemlock ecosystem in northern Idaho and adjacent portions of Montana and Washington (Ferguson and others 1986). Version 2 of the model, reported in this paper, expands the geographic area, includes additional habitat types, and includes the influence of western spruce budworm (Choristoneura occidentalis) on regeneration success.

Version 2 of the Regeneration Establishment Model is calibrated for western Montana as well as central and northern Idaho. Figure 1 shows the locations of sampled stands. Habitat type series included in the model are the Pseudotsuga menziesii, Abies grandis, Thuja plicata, Tsuga heterophylla, Abies lasiocarpa, and some of the Tsuga mertensiana series.

The effects of western spruce budworm defoliation on regeneration success are represented in the regeneration model. Western spruce budworm reduces growth, crown volume, and cone crops of host trees, and increases top-kill, mortality, deformities, and predisposition to other insects and disease. Host species in the study area are western larch (Larix occidentalis), Douglas-fir (Pseudotsuga menziesii), grand fir (Abies grandis), Engelmann spruce (Picea engelmannii), and subalpine fir (Abies lasiocarpa).

To be consistent, we use scientific names and four-letter abbreviations when discussing habitat types. An example is the Abies grandis/Clintonia uniflora habitat type, abbreviated ABGR/CLUN. When discussing tree species, we use the common name; for instance, grand fir.

This paper presents details about data collection, predictive equations, model development, and model behavior. A user's guide to version 2 of the Regeneration Establishment Model is available (Ferguson and Crookston 1991). Silvicultural interpretations of the model will be presented in another paper (Carlson and Ferguson in preparation). 


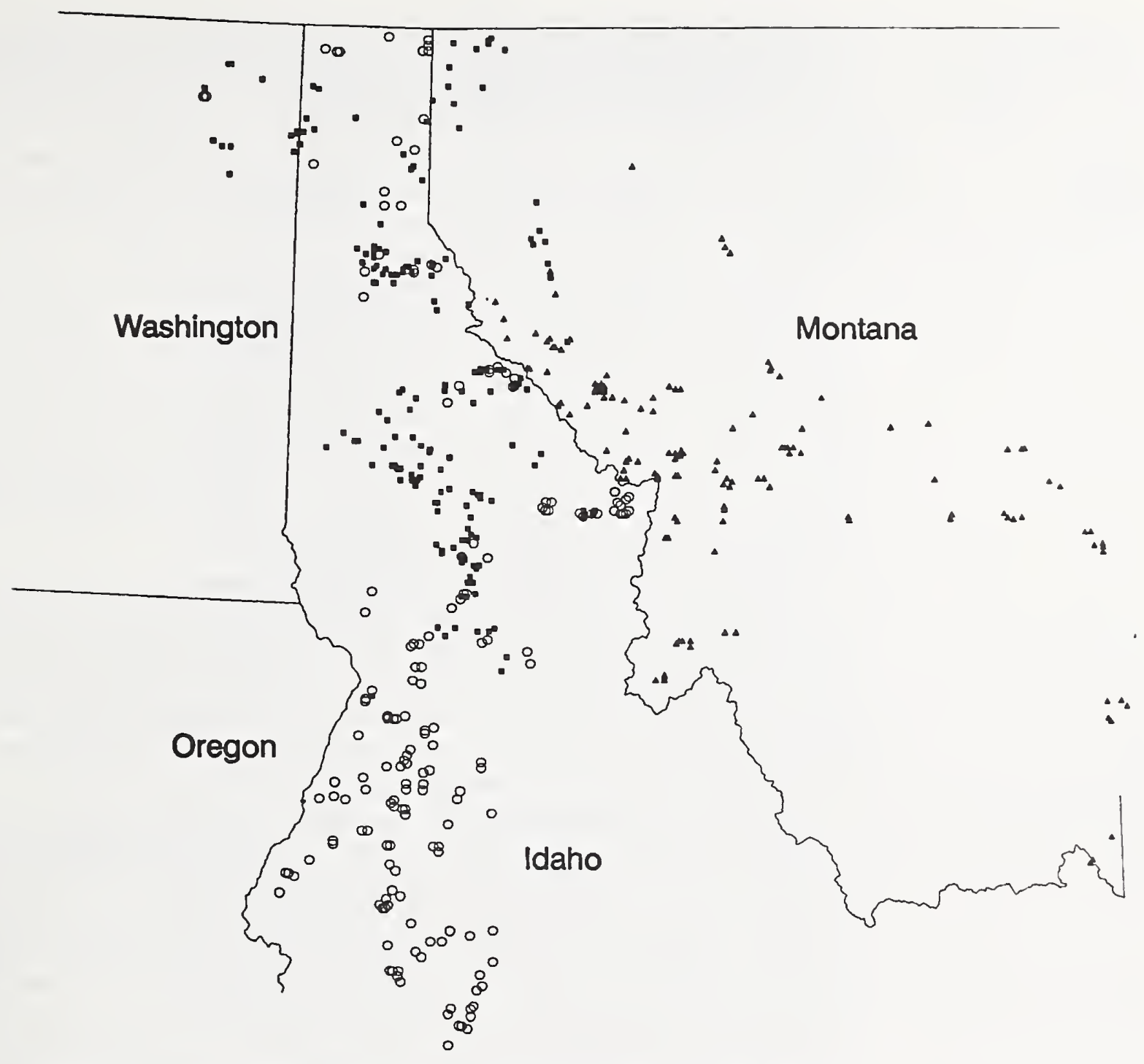

Figure 1-Location of study sites for version 2 of the Regeneration Establishment Model. Triangles are stands sampled by Carlson in 1979-82. Squares are stands sampled by Ferguson and others (1986) in 1975-76. Circles are stands sampled by Ferguson in 1979-82.

\section{STUDY DESIGN}

Data for version 2 of the regeneration model were collected during three studies. The grand fir-cedar-hemlock ecosystem of northern Idaho, sampled in 1975-76, was used to develop version 1 of the regeneration model (Ferguson and others 1986). Data from western Montana were collected by Carlson from 1979-82. Data in central Idaho and the Pseudotsuga menziesii and Abies lasiocarpa series in northern Idaho were collected by Ferguson from 1979-82. Data collection was similar among the three studies. These data were combined to develop version 2 of the regeneration model.

A stratified random design was used to select stands that were harvested 2 to 20 years prior to sampling. Stratification variables were habitat type series, site preparation, regeneration method, and history of budworm defoliation. Four to five stands within each stratification category were randomly chosen for sampling. 
Although stands were used to select study areas, we were interested in sampling microsites within stands. A series of $1 / 300$-acre plots were sampled in each stand. After obtaining stand histories and stereo aerial photographs for each selected stand, either transects or a sampling grid was used to systematically locate about 25 plot centers per stand. In Idaho, transects crossed through areas observable on aerial photographs that varied in such things as aspect, overstory density, site preparation, and topographic position. In Montana, a sampling grid was used to locate plot centers.

Each sample point was the center of a $1 / 300$-acre circular fixed area plot and a variable radius plot for sampling the overstory (if present) with a 10 basal area factor prism. Each plot was made as independent as possible by recording plot attributes-habitat type, slope, aspect, type of site preparation, topographic position, and residual overstory density by species. Systematically spacing plots also helped maintain independence among plots within stands because plots were dispersed throughout the stand. The year of cutting, geographic location, elevation, and budworm defoliation history were stand variables that did not differ among plots within a stand.

Plots within stands could represent different "years since last disturbance" due to different years of site preparation. Untreated plots were last disturbed when the stand was harvested. Plots mechanically prepared or burned were last disturbed when the site preparation took place-either, or both, could occur after the harvest year. Because the year of site preparation can take place after the year of harvest, we use "years since last disturbance," rather than stand age, to predict regeneration.

Established conifer regeneration on each plot in the Idaho studies was counted by species; in the Montana study up to 10 established trees were recorded per plot. Species included in the model are shown in table 1. Mountain hemlock (Tsuga mertensiana) could not be included in the model because of insufficient data. Table 1 also lists the minimum establishment heights by species-these are 0.5 foot for shade-tolerant species and 1.0 foot for shadeintolerant species. Minimum heights roughly correspond to the height of a 3-year-old tree. Maximum size for all regeneration was 2.95 inches diameter at breast height (d.b.h.). Tree heights were measured as of the end of the previous growing season to ensure that all trees sampled during one field season used the same standards for establishment.

Tree height to the nearest 0.1 foot, tree age at groundline, and tree condition (damage, insects, disease, and so on) were recorded on a subsample of regeneration called "best trees." Best trees were chosen by the following rules:

1. Select the two tallest trees on each $1 / 300$-acre plot regardless of species.

2. Select the one tallest tree of each additional species present on the plot.

3. If the first two rules do not total four trees, select in order of descending height from any remaining trees until at least four trees, if present, are chosen.

One site preparation treatment was recorded for each $1 / 300$-acre plot. It was the treatment that covered the largest proportion of the plot-mechanical, burn, no treatment, or road. The "road" category included all road cuts, road fills, and unmaintained roadbeds. Plots that occurred on maintained roadbeds were not sampled. The intensity of each site preparation was not recorded because this was more difficult to determine as years since disturbance increased.

National Forests were used as independent variables in data analyses because they divide the study area into units that can account for variation in latitude, longitude, climate, and so on. 
Table 1-Scientific name, common name, abbreviation, and minimum establishment height for regeneration. Species are listed in approximate order of increasing shade tolerance. This order will be maintained in tables that provide equations by species

\begin{tabular}{|c|c|c|c|}
\hline Scientific name & Common name & $\begin{array}{l}\text { Prognosis } \\
\text { Model } \\
\text { abbreviation }\end{array}$ & $\begin{array}{l}\text { Minimum } \\
\text { height }\end{array}$ \\
\hline & & & Feet \\
\hline $\begin{array}{l}\text { Pinus ponderosa Dougl. } \\
\text { ex Laws. var. } \\
\text { ponderosa }\end{array}$ & ponderosa pine & PP & 1.0 \\
\hline $\begin{array}{l}\text { Larix occidentalis } \\
\text { Nutt. }\end{array}$ & western larch & L & 1.0 \\
\hline $\begin{array}{l}\text { Pinus contorta Dougl. } \\
\text { ex Loud. }\end{array}$ & lodgepole pine & LP & 1.0 \\
\hline $\begin{array}{l}\text { Picea engelmannii } \\
\text { Parry ex Engelm. }\end{array}$ & Engelmann spruce & $S$ & .5 \\
\hline $\begin{array}{l}\text { Pseudotsuga menziesii } \\
\text { var. glauca (Beissn.) } \\
\text { Franco }\end{array}$ & Douglas-fir & DF & 1.0 \\
\hline $\begin{array}{l}\text { Pinus monticola Dougl. } \\
\text { ex D. Don }\end{array}$ & western white pine & WP & 1.0 \\
\hline $\begin{array}{l}\text { Abies grandis (Dougl. } \\
\text { ex D. Don) Lindl. }\end{array}$ & grand fir & GF & .5 \\
\hline $\begin{array}{l}\text { Tsuga heterophylla } \\
\text { (Raf.) Sarg. }\end{array}$ & western hemlock & WH & .5 \\
\hline $\begin{array}{l}\text { Abies lasiocarpa } \\
\text { (Hook.) Nutt. }\end{array}$ & subalpine fir & AF & .5 \\
\hline $\begin{array}{l}\text { Thuja plicata Donn ex } \\
\text { D. Don }\end{array}$ & western redcedar & $\mathrm{C}$ & .5 \\
\hline
\end{tabular}

The presence of shrubs, forbs, and grasses was recorded on each $1 / 300$-acre plot. Each species was characterized by recording average height and percentage of the plot area covered by a vertical projection of the crown on the ground. Coverage could exceed 100 percent because of overlapping layers of shrubs, forbs, and grasses. These data were not used to predict regeneration success because it was not possible to retrospectively determine coverage at the time of seedling establishment. A model of secondary succession for shrubs, forbs, and grasses has been developed using the Idaho data (Moeur 1985).

\section{MODELING TECHNIQUE}

The technique for developing equations follows the example of Hamilton and Brickell (1983) for two-state systems. Each plot in the sample is in one of two states: stocked with at least one established seedling or nonstocked. All plots are used to develop equations predicting the probability of a plot being stocked. Then, only stocked plots are used to estimate the number of trees on the plot, number of species, species composition, and seedling heights.

The probability of stocking $t$ years after disturbance is estimated by a logistic equation (Hamilton 1974) within the interval [0,1]. After the attributes of 
stocked plots are estimated, the probability of stocking is used to scale stocked plot attributes to a per-acre basis. As an example, suppose five plots are being projected and the following are predicted for the probability of stocking (PS) and number of trees per stocked plot (TPSP):

\section{Predicted probability of stocking}

0.60

.25

.80

.50

.45

\section{Predicted number of trees per stocked plot (TPSP)}

3

1

2

5

1

\section{Predicted trees per acre = (PS * TPSP * 300)/N where $N$ is 5 plots}

108

15

96

150

27

Predicted total

trees per acre

396

The third column shows how the probability of stocking is used to scale results of stocked plot analyses to a per-acre basis. The " 300 " in the third column is the inverse of the plot size used in the study and the " $N$ " is the number of plots being used to represent the stand. Predicted total trees per acre is 396. Species, size, and other tree attributes are determined during other steps in the model.

\section{Logistic}

Regression Equations
Many of the regeneration data are distributed dichotomously-plots are either stocked with at least one established seedling or they are nonstocked, each of the 10 species was either established on a plot or it was not, and so on. Response surfaces are sigmoid-shaped.

A nonlinear logistic algorithm called RISK (Hamilton 1974) was used to predict probabilities for dichotomously distributed dependent variables. The logistic equation is:

$$
P=\left(1+e^{-\left(\Sigma \beta_{i} X_{i}\right)}\right)^{-1}
$$

where

$$
\begin{aligned}
P & =\text { probability } \\
e & =\text { the base of natural logarithms } \\
\beta_{i} & =\text { vector of regression coefficients } \\
X_{i} & =\text { vector of independent variables. }
\end{aligned}
$$

The predicted probability $(P)$ is continuous and bounded within the interval $[0,1]$. RISK can use up to 30 independent variables.

Goodness of fit for equations was evaluated at the 0.05 significance level. RISK output includes four types of statistics that can be used to evaluate goodness of fit: Student- $t$ ratios for each regression coefficient, chi-square values for 21 divisions within the probability interval [0,1], total chi-square for the 21 divisions, and an analysis of variance table showing the amount of variation explained by regression.

A fifth goodness-of-fit criterion was how close the error mean square was to 1.0 in the analysis of variance table. As the population size increases, the limiting value for the error mean square is 1.0 , rather than 0.0 (Hamilton 1974). We found that in successive iterations of the RISK algorithm, the error mean square would approach 1.0 unless the equation was unstable; thus, error mean squares substantially different from 1.0 usually indicate poor equation formulation. 
Linear Regression Equations

\section{Weibull}

Distributions

Habitat Type Groupings
Linear regression was used to estimate heights of best trees. Goodness of fit was evaluated at the 0.05 significance level. The best transformation of the dependent variable was found to be the natural logarithm of tree height. Various transformations of independent variables were also explored and used.

In some steps of the regeneration model, it is important to mimic the distribution of the dependent variable. An example is the number of seedlings established on stocked plots, which has a reversed J-shape distribution. For these situations, the distribution is modeled with Weibull cumulative density distributions (Bailey and Dell 1973). The form of the equation for a two parameter Weibull cumulative density distribution is:

$$
\mathrm{F}(x)=1-\operatorname{EXP}\left[-(x / B)^{C}\right]
$$

where

$$
\begin{aligned}
\mathrm{F}(x) & =\text { cumulative density } \\
x & =\text { dependent variable being modeled } \\
B & =\text { Weibull scale parameter } \\
C & =\text { Weibull shape parameter. }
\end{aligned}
$$

The area bounded by the Weibull equation is within the interval $[0,1]$. Equation 2 can be solved for $x$ as shown by Bailey and Dell (1973):

$$
x=B[-\ln (1-\mathrm{F}(x))]^{1 / C}
$$

A uniformly distributed pseudo-random number in the interval $[0,1]$ can be substituted for $F(x)$ in equation 3 , resulting in an unbiased choice for $x$. Plot replication in the regeneration model results in enough random draws that the distribution is approximated.

Bailey and Dell (1973) also discuss coefficients for the $C$ (shape) parameter. If $C$ is less than 1, the distribution has a reversed J shape. If $C$ equals 1 , the distribution is exponential. If $C$ is between 1 and 3.6, the distribution is mound-shaped and positively skewed. When $C$ is approximately 3.6, a normal distribution results. And when $C$ is greater than 3.6, the distribution is mound-shaped and negatively skewed.

Version 1 of the regeneration model predicted regeneration on four broadly defined habitat types using the habitat type classification system of Daubenmire and Daubenmire (1968). Since then, classification of habitat types has been refined for northern Idaho (Cooper and others 1991). We were fortunate that Neiman, one of the authors of the 1991 northern Idaho classification, was available to update data collected during 1975-76 to the 1991 classification. Each plot sampled during the 1975-76 study was reclassified by reviewing the original field sheets on which field crews had listed species of shrubs, forbs, and grasses by plot.

Thus, for northern Idaho we used the habitat type classification of Cooper and others (1991), for Montana we used the classification of Pfister and others (1977), and for central Idaho we used the classification of Steele and others (1981). This resulted in 93 different habitat types and phases being sampled.

It was necessary to combine similar habitat types into groups to reduce independent variables to a reasonable number. This was done before fitting equations. Groupings were made after statistical analyses by habitat types that compared the percentage of stocked plots, trees per stocked plot, and species per stocked plot. These analyses provided ideas for preliminary groupings. Preliminary groupings were reviewed by forest ecologists, and their suggestions were used to develop the final groupings. 


\section{Western Spruce \\ Budworm \\ Defoliation \\ History}

\section{Planting}

Variables in the Model
The resulting 16 habitat type groups are shown in table 2. Analyses used to develop the groups are found in appendix A. The groups combine habitat types within climax series that are similar during the regeneration phase of stand development. Habitat type groups would likely be different for other purposes-diameter growth, mortality, canopy cover, and so on.

The influence of western spruce budworm on regeneration success was a major focus of the studies conducted in Montana and Idaho during 1979-82. Defoliation histories were collected by stand for the period 5 years before the harvest to the year prior to field sampling.

In Montana, past budworm activity was indexed by analysis of increment cores using the procedure of Carlson and McCaughey (1982). In Idaho, historical aerial defoliation maps were used to determine which years, if any, a stand was within a defoliated area. Using aerial defoliation maps, it was also possible to determine defoliation histories for stands in the 1975-76 study. The vast majority of stands from the 1975-76 study were not in areas defoliated by budworm.

The historical aerial defoliation maps outline areas of low, moderate, and heavy defoliation as seen by an entomologist from an airplane. Boundaries between levels of budworm defoliation are approximate. There is also variation in defoliation within outlined levels of defoliation. We felt the appropriate way to use budworm histories in developing a regeneration model was as a dichotomous variable. For each year, the stand either was in a defoliated area or it was not. This approach also allowed consistent use of data collected in Montana and Idaho.

Both planted and unplanted stands were sampled. Sampling only naturally regenerated stands may have biased the sample, because stands that were difficult to regenerate were more likely to have been planted. During the first few years of data collection, crews attempted to identify planted trees on plots, but this was not easy to determine retrospectively. Plots from planted stands were coded for analyses as a class (dummy) variable. Coefficients estimated by regression analysis for planted stands are not used in the model, so that predictions are only for natural regeneration. Model users then specify planting for the stand, which is added to the natural regeneration predicted by the model. They select the species, density, year of planting, and survival of planted trees.

The variables used in the regeneration model are those generally recorded in forest inventories in the Northern Rocky Mountains. This means that most inventories are already designed to collect the information needed to use the regeneration model, or could easily do so.

Table 3 provides definitions for variables used in the regeneration model. These names for variables are used in tables of regression coefficients (appendix B).

During equation development, goodness of fit was evaluated at the 0.05 significance level. Nonsignificant independent variables were eliminated from equations except those we considered to be part of groups. An example of a group is class variables for site preparations. The entire group was kept in the equation if one of the coefficients was significant. 
Table 2-Number of plots by habitat type and habitat type group. Within a habitat type group, habitat types are listed in decreasing order of number of plots sampled. Subsequent tables will use only the first habitat type to identify the group

\begin{tabular}{|c|c|c|}
\hline Group & $\begin{array}{c}\text { Habitat types' } \\
\text { (number of } 1 / 300 \text {-acre plots) }\end{array}$ & $\begin{array}{l}\text { No. plots } \\
\text { in group }\end{array}$ \\
\hline 1 & $\begin{array}{l}\text { PSMENAGL, LIBO, VACA } \\
\begin{array}{ccc}(178) & \text { (92) } & (26)\end{array}\end{array}$ & 296 \\
\hline 2 & $\begin{array}{l}\text { PSME/CARU, CAGE, AGSP, FEID } \\
\begin{array}{lll}(264) & (122) & (26)\end{array}\end{array}$ & 417 \\
\hline 3 & $\begin{array}{l}\text { PSME/PHMA, ACGL } \\
\begin{array}{l}(815) \\
\text { (17) }\end{array}\end{array}$ & 832 \\
\hline 4 & 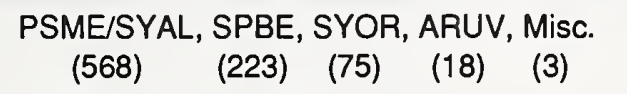 & 887 \\
\hline 5 & $\begin{array}{l}\text { ABGR/LIBO, CLUN-XETE } \\
\begin{array}{cl}(199) & (74)\end{array}\end{array}$ & 273 \\
\hline 6 & 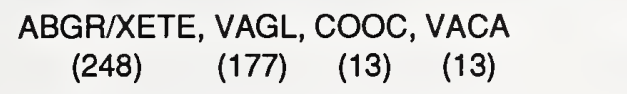 & 451 \\
\hline 7 & ABGR/CLUN (except CLUN-XETE) & 1,865 \\
\hline 8 & $\begin{array}{cccc}\text { ABGR/SPBE, } & \text { ACGL, PHMA, ASCA, SETR } \\
\begin{array}{cccc}(447) & (251) & (151) & (138)\end{array}\end{array}$ & 989 \\
\hline 9 & THPLAIl & 2,180 \\
\hline 10 & TSHE/All & 1,387 \\
\hline 11 & $\begin{array}{l}\text { ABLANAGL, VASC, VACA } \\
\begin{array}{cl}(176) & (110) \\
(56)\end{array}\end{array}$ & 342 \\
\hline 12 & $\begin{array}{c}\text { ABLAXXETE, LIBO } \\
\begin{array}{c}(533) \\
(142)\end{array}\end{array}$ & 675 \\
\hline 13 & $\begin{array}{l}\text { ABLANCLUN, GATR } \\
\begin{array}{l}(673) \\
\text { (7) }\end{array}\end{array}$ & 680 \\
\hline 14 & $\begin{array}{l}\text { ABLA/CAGE, CARU, ACGL, SPBE } \\
\begin{array}{lll}(105) & \text { (73) } & \text { (36) }\end{array}\end{array}$ & 228 \\
\hline \multirow[t]{2}{*}{15} & $\begin{array}{l}\text { ABLA/MEFE, ALSI } \\
\begin{array}{c}\text { (353) } \\
\text { (31) }\end{array}\end{array}$ & \\
\hline & $\begin{array}{l}\text { TSME/CLUN, XETE, MEFE, STAM } \\
\begin{array}{lll}\text { (31) } & \text { (31) } & \text { (9) }\end{array}\end{array}$ & 460 \\
\hline 16 & $\begin{array}{l}\text { ABLANCACA, STAM, LUHI } \\
\begin{array}{lll}(107) & \text { (55) }\end{array}\end{array}$ & 166 \\
\hline Total & & 12,128 \\
\hline
\end{tabular}

'Species codes for habitat type abbreviations:

\begin{tabular}{|c|c|c|c|}
\hline $\begin{array}{l}\text { ABGR } \\
\text { ACGL } \\
\text { ALSI } \\
\text { ASCA } \\
\text { CAGE } \\
\text { CLUN } \\
\text { FEID } \\
\text { LIBO } \\
\text { MEFE } \\
\text { PSME } \\
\text { SPBE } \\
\text { SYAL } \\
\text { THPL } \\
\text { TSME } \\
\text { VAGL } \\
\text { XETE }\end{array}$ & $\begin{array}{l}\text { Abies grandis } \\
\text { Acer glabrum } \\
\text { Alnus sinuata } \\
\text { Asarum caudatum } \\
\text { Carex geyeri } \\
\text { Clintonia uniflora } \\
\text { Festuca idahoensis } \\
\text { Linnaea borealis } \\
\text { Menziesia ferruginea } \\
\text { Pseudotsuga menziesii } \\
\text { Spiraea betulifolia } \\
\text { Symphoricarpos albus } \\
\text { Thuja plicata } \\
\text { Tsuga mertensiana } \\
\text { Vaccinium globulare } \\
\text { Xerophyllum tenax }\end{array}$ & $\begin{array}{l}\text { ABLA } \\
\text { AGSP } \\
\text { ARUV } \\
\text { CACA } \\
\text { CARU } \\
\text { COOC } \\
\text { GATR } \\
\text { LUHI } \\
\text { PHMA } \\
\text { SETR } \\
\text { STAM } \\
\text { SYOR } \\
\text { TSHE } \\
\text { VACA } \\
\text { VASC }\end{array}$ & $\begin{array}{l}\text { Abies lasiocarpa } \\
\text { Agropyron spicatum } \\
\text { Arctostaphylos uva-ursi } \\
\text { Calamagrostis canadensis } \\
\text { Calamagrostis rubescens } \\
\text { Coptis occidentalis } \\
\text { Galium triflorum } \\
\text { Luzula hitchcockii } \\
\text { Physocarpus malvaceus } \\
\text { Senecio triangularis } \\
\text { Streptopus amplexifolius } \\
\text { Symphoricarpos oreophilus } \\
\text { Tsuga heterophylla } \\
\text { Vaccinium caespitosum } \\
\text { Vaccinium scoparium }\end{array}$ \\
\hline
\end{tabular}


Table 3-Definition of variables used in the Regeneration Establishment Model

\begin{tabular}{|c|c|}
\hline Variable & Definition \\
\hline ASP & Plot aspect converted to radians. \\
\hline SLO & Plot slope tangent (slope percent/100). \\
\hline TIME & Number of years since last disturbance to plot. \\
\hline REGT & Number of years since last disturbance without budworm. \\
\hline BWAF & $\begin{array}{l}\text { Number of years since last disturbance with budworm. } \\
\text { Note: REGT + BWAF = TIME }\end{array}$ \\
\hline BWB4 & Number of budworm years in the 5 years before last disturbance. \\
\hline \multirow[t]{2}{*}{ SQREGT } & $\begin{array}{l}\text { Sum of square roots for each year without budworm. } \\
\text { SQREGT }=\Sigma\left\{\left(\mathrm{TIME}^{1 / 2}\right)-\left[\left(\mathrm{TIME}^{1}-1\right)^{1 / 2}\right]\right\} \text { for those years without budworm. } \\
\text { Suppose there was no budworm in years } 1,2 \text {, and } 5 \text {. } \\
\text { Then: }\end{array}$ \\
\hline & 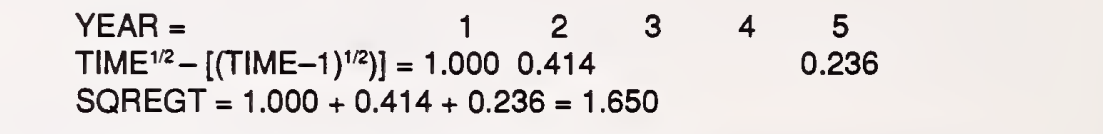 \\
\hline \multirow[t]{3}{*}{ SQBWAF } & $\begin{array}{l}\text { Sum of square roots for each year with budworm. } \\
\text { SQBWAF }=\Sigma\left\{\left(T_{I M E^{1 / 2}}\right)-\left[(T I M E-1)^{1 / 2}\right]\right\} \text { for those years with budworm. } \\
\text { Suppose there was budworm in years } 3 \text { and } 4 \text {. Then: }\end{array}$ \\
\hline & $\begin{array}{llllll}\text { YEAR }= & 1 & 2 & 3 & 4 & 5 \\
\left.T_{I M E}^{1 / 2}-\left[(T I M E-1)^{1 / 2}\right)\right]= & & 0.318 & 0.268 & \\
\text { SQBWAF }=0.318+0.268=0.586 & & & & \end{array}$ \\
\hline & $\begin{array}{l}\text { The effect of this variable is that budworm defoliation near the beginning } \\
\text { of the regeneration period will be more detrimental than defoliation near } \\
\text { the end of the regeneration period. } \\
\text { Note: (SQREGT + SQBWAF) }{ }^{2}=\text { TIME }\end{array}$ \\
\hline ELEV & Stand elevation to the nearest 100 feet; for example, $35=3,500$ feet. \\
\hline BAA & Plot residual overstory basal area (ftªcre), reset to 1.0 if 0.0 . \\
\hline NONE & Class variable for no site preparation to the plot. \\
\hline $\mathrm{MECH}$ & Class variable for mechanical disturbance to the plot. \\
\hline BURN & Class variable for burn disturbance to the plot. \\
\hline ROAD & $\begin{array}{l}\text { Class variable for plots that occur on road cuts, road fills, or unmaintained } \\
\text { roadbeds. }\end{array}$ \\
\hline PLANT & $\begin{array}{l}\text { Class variable for planted stands (probability of stocking equations and } \\
\text { equations for determining the number of species on stocked plots) or the } \\
\text { stand planted to the same species being predicted (probability of species } \\
\text { occurrence equations). }\end{array}$ \\
\hline TPSP & $\begin{array}{l}\text { Number of regeneration-size trees on the plot, conditional on the plot } \\
\text { being stocked with at least one established seedling. }\end{array}$ \\
\hline OVER & Class variable for the presence of the same species in the variable radius plot. \\
\hline BOTTOM & Class variable for bottom topographic position. \\
\hline LOWER & Class variable for lower-slope topographic position. \\
\hline MIDSLOPE & Class variable for midslope topographic position. \\
\hline UPPER & Class variable for upper-slope topographic position. \\
\hline RIDGE & Class variable for ridge topographic position. \\
\hline AGE & Tree age at groundline. \\
\hline
\end{tabular}




\section{RESULTS}

This section describes equations that were statistically derived from the data. Table 4 shows the range of data for independent variables used to develop the model. Data represent 2-20 years since disturbance, all aspects, 0-390 square feet of residual overstory basal area, 2,400-7,400 feet elevation, four site preparation methods, $0-110$ percent slopes, and up to 16 years of budworm defoliation. The year of harvest for stands included in this study ranged from 1959 through 1978.

Table 5 shows the number of plots sampled by classification variables of regeneration method, site preparation, habitat type series, and budworm history. Except for the road site preparation category, this is the same information matrix used in the stratified random selection of stands. Some

Table 4-Number of plots by classes for independent variables used to develop version 2 of the Regeneration Establishment Model. Classes used below show the range of data-analyses used the data as continuous variables unless otherwise noted in appendix $B$

\begin{tabular}{|c|c|c|c|c|c|}
\hline Class & No. plots & Class & No. plots & Class & No. plots \\
\hline Years since & & Site preparation & & Aspect (degrees) & \\
\hline last disturbance & & None & 5,648 & Flat & 204 \\
\hline 2 & 58 & Mechanical & 3,055 & $346-45$ & 1,763 \\
\hline 3 & 768 & Burn & 2,742 & $46-105$ & 2,009 \\
\hline 4 & 849 & Road & 683 & $106-165$ & 2,171 \\
\hline 5 & 974 & & & $166-225$ & 1,996 \\
\hline 6 & 986 & Regeneration & & $226-285$ & 2,016 \\
\hline 7 & 934 & method & & $286-345$ & 1,969 \\
\hline 8 & 822 & Clearcut & $\begin{array}{l}4,884 \\
2,07\end{array}$ & & \\
\hline 9 & 914 & Seedtree & 2,207 & Topographic & \\
\hline 10 & 762 & Shelterwood & 2,872 & position & \\
\hline 11,12 & 1,549 & Selection & 2,165 & Bottom slope & 628 \\
\hline 13,14 & 1,233 & Regeneration mode & & Lower slope & 820 \\
\hline 15,16 & 1,062 & Natural & & Midslope & 7,720 \\
\hline 17,18 & 631 & Planted & $\begin{array}{l}7,024 \\
504\end{array}$ & Upper slope & 2,634 \\
\hline 19,20 & 586 & & 4,504 & Ridgetop & 326 \\
\hline & & Slope (percent) & & No. of budworm & \\
\hline $\begin{array}{l}\text { Residual basal } \\
\text { area ( } \mathrm{ft}^{2} / \text { acre) }\end{array}$ & & Flat & 313 & years in the 5 years & \\
\hline $\begin{array}{c}\text { area }\left(\mathrm{ft}^{2} / \mathrm{acre}\right) \\
0\end{array}$ & & $1-10$ & 2,187 & before harvest & \\
\hline 0 & 6,104 & $11-20$ & 2,822 & 0 & 9,354 \\
\hline 10 & 1,089 & $21-30$ & 2,637 & 1 & $\begin{array}{r}9,304 \\
684\end{array}$ \\
\hline 20 & 1,034 & $31-40$ & 1,794 & $\begin{array}{l}1 \\
2\end{array}$ & 684 \\
\hline $30-40$ & 1,344 & $41-50$ & 1,220 & 2 & 579 \\
\hline $50-60$ & 913 & $51-80$ & 1,095 & 3 & 267 \\
\hline $70-80$ & 609 & $81-110$ & 60 & 4 & 384 \\
\hline $90-100$ & 441 & & & 5 & 860 \\
\hline $110-200$ & 549 & Nearest National & & No. of budworm & \\
\hline $210-390$ & 45 & Forest & & years after harvest & \\
\hline Elevation & & Gallatin & 178 & 0 & 7,232 \\
\hline (nearest 100 feet) & & Helena & 371 & 1 & 338 \\
\hline $24-27$ & & Deerlodge & 321 & 2 & 588 \\
\hline $28-31$ & $\begin{array}{l}204 \\
852\end{array}$ & Bitterroot & 461 & 3 & 678 \\
\hline $32-35$ & 852 & Flathead & 199 & 4 & 635 \\
\hline $36-39$ & 997 & Lolo & 1,446 & 5 & 474 \\
\hline $\begin{array}{l}30-39 \\
40-43\end{array}$ & 1,030 & Kootenai & 356 & 6 & 388 \\
\hline $\begin{array}{l}40-43 \\
44-47\end{array}$ & 1,879 & Panhandle & 2,933 & 7 & 261 \\
\hline $\begin{array}{l}44-47 \\
48-51\end{array}$ & 1,668 & Colville & 271 & 8 & 401 \\
\hline $\begin{array}{l}48-51 \\
52-55\end{array}$ & 1,721 & Clearwater & 2,527 & 9 & 366 \\
\hline $52-55$ & 1,178 & Nez Perce & 1,037 & 10 & 318 \\
\hline $56-59$ & 1,079 & Payette & 1,399 & 11 & 132 \\
\hline $60-63$ & 741 & Boise & 629 & 12 & 171 \\
\hline $64-67$ & 445 & & & 13,14 & 100 \\
\hline $68-74$ & 334 & & & $\begin{array}{l}13,14 \\
15,16\end{array}$ & 46 \\
\hline
\end{tabular}


Table 5-Number of $1 / 300$-acre plots sampled by classification variables

\begin{tabular}{|c|c|c|c|c|c|c|c|c|c|c|c|c|c|c|c|c|c|}
\hline \multirow{3}{*}{$\begin{array}{l}\text { Budworm } \\
\text { defoliation } \\
\text { history }\end{array}$} & \multirow{3}{*}{$\begin{array}{l}\text { Habitat } \\
\text { type } \\
\text { series }^{1}\end{array}$} & \multicolumn{16}{|c|}{ Regeneration method and site preparation } \\
\hline & & \multicolumn{4}{|c|}{ Clearcut } & \multicolumn{4}{|c|}{ Seedtree } & \multicolumn{4}{|c|}{ Shelterwood } & \multicolumn{4}{|c|}{ Selection } \\
\hline & & None & Mech & Burn & Road & None & Mech & Burn & Road & None & Mech & Burn & Road & None & Mech & Burn & Road \\
\hline \multirow[t]{5}{*}{ No } & PSME & 80 & 71 & 70 & 11 & 82 & 30 & 11 & 7 & 176 & 124 & 61 & 18 & 302 & 67 & 25 & 13 \\
\hline & ABGR & 197 & 171 & 163 & 41 & 229 & 139 & 87 & 41 & 135 & 61 & 19 & 3 & 211 & 53 & 18 & 9 \\
\hline & THPL & 193 & 193 & 251 & 44 & 133 & 129 & 4 & 31 & 265 & 31 & 10 & 29 & 256 & 31 & 3 & 30 \\
\hline & TSHE & 275 & 123 & 232 & 53 & 150 & 34 & 3 & 16 & 172 & 51 & 2 & 13 & 122 & 48 & 35 & 17 \\
\hline & $A B L A$ & 149 & 121 & 218 & 18 & 134 & 109 & 51 & 14 & 139 & 68 & 20 & 13 & 106 & 16 & 5 & 8 \\
\hline \multicolumn{2}{|l|}{ Subtotals } & 894 & 679 & 934 & 167 & 728 & 441 & 156 & 109 & 887 & 335 & 112 & 76 & 997 & 215 & 86 & 77 \\
\hline \multirow[t]{5}{*}{ Yes } & PSME & 66 & 155 & 146 & 8 & 138 & 63 & 75 & 3 & 275 & 61 & 72 & 3 & 153 & 50 & 16 & 0 \\
\hline & ABGR & 174 & 251 & 493 & 51 & 99 & 56 & 47 & 15 & 304 & 171 & 70 & 32 & 113 & 90 & 22 & 13 \\
\hline & THPL & 122 & 24 & 101 & 16 & 29 & 16 & 0 & 2 & 99 & 35 & 14 & 18 & 53 & 10 & 2 & 6 \\
\hline & TSHE & 2 & 1 & 7 & 1 & 0 & 0 & 0 & 0 & 8 & 6 & 5 & 2 & 8 & 1 & 0 & 0 \\
\hline & $A B L A$ & 94 & 168 & 282 & 48 & 89 & 91 & 40 & 10 & 135 & 89 & 49 & 14 & 181 & 47 & 13 & 12 \\
\hline \multicolumn{2}{|l|}{ Subtotals } & 458 & 599 & 1,029 & 124 & 355 & 226 & 162 & 30 & 821 & 362 & 210 & 69 & 508 & 198 & 53 & 31 \\
\hline \multirow[t]{2}{*}{ Totals } & & 1,352 & 1,278 & 1,963 & 291 & 1,083 & 667 & 318 & 139 & 1,708 & 697 & 322 & 145 & 1,505 & 413 & 139 & 108 \\
\hline & \multicolumn{17}{|c|}{$\Sigma=12,128$} \\
\hline
\end{tabular}

'See table 2, footnote 1, for habitat type abbreviations.

Probability of Stocking combinations were difficult to find; for example, selection cuttings that were burned. Also, spruce budworm defoliation was rarely found in Tsuga heterophylla habitat types.

Probability of stocking equations predict the probability of at least one established seedling on a $1 / 300$-acre plot. Separate equations were developed for the Pseudotsuga menziesii, Abies grandis, Thuja plicata/Tsuga heterophylla, and Abies lasiocarpa series (appendix B, table 9). A fifth equation was developed for the 683 plots that were sampled on road cuts, road fills, and unmaintained roadbeds.

The equations given in appendix $B$, table 9 , were exercised to show the effect of important independent variables on the probability of stocking. In figures 2 to 9 , independent variables are held constant except those being displayed. Default conditions are an Abies grandis/Clintonia uniflora habitat type on the Idaho Panhandle National Forests, north aspect, 30 percent slope, 10 years since last disturbance, 3,500 feet elevation, no residual overstory, no site preparation, and no planting.

Figure 2 illustrates the interaction of slope and aspect on predicted probability of stocking. On southerly slopes, the probability of stocking decreases quite rapidly with increasing slopes. On northerly aspects, the probability of stocking increases only slightly as slope increases.

Increases in the probability of stocking over time differ by aspect (fig. 3). North aspects increase the most rapidly and attain the highest stocking level. South aspects have the poorest stocking over time. East and west aspects are intermediate between north and south. For equations predicting the probability of stocking, the highest rate of stocking over time occurs at the optimum aspect and the lowest rate of stocking occurs at the poorest aspect.

Habitat types also differ in the rate of stocking over time. These differences are illustrated in figure 4. Of the four habitat types shown (each representing a different equation), the Thuja/Tsuga series has the highest rate of stocking and achieves the highest stocking level. The probability of stocking on the Abies grandis series increases nearly as quickly as the Thuja/Tsuga series, 


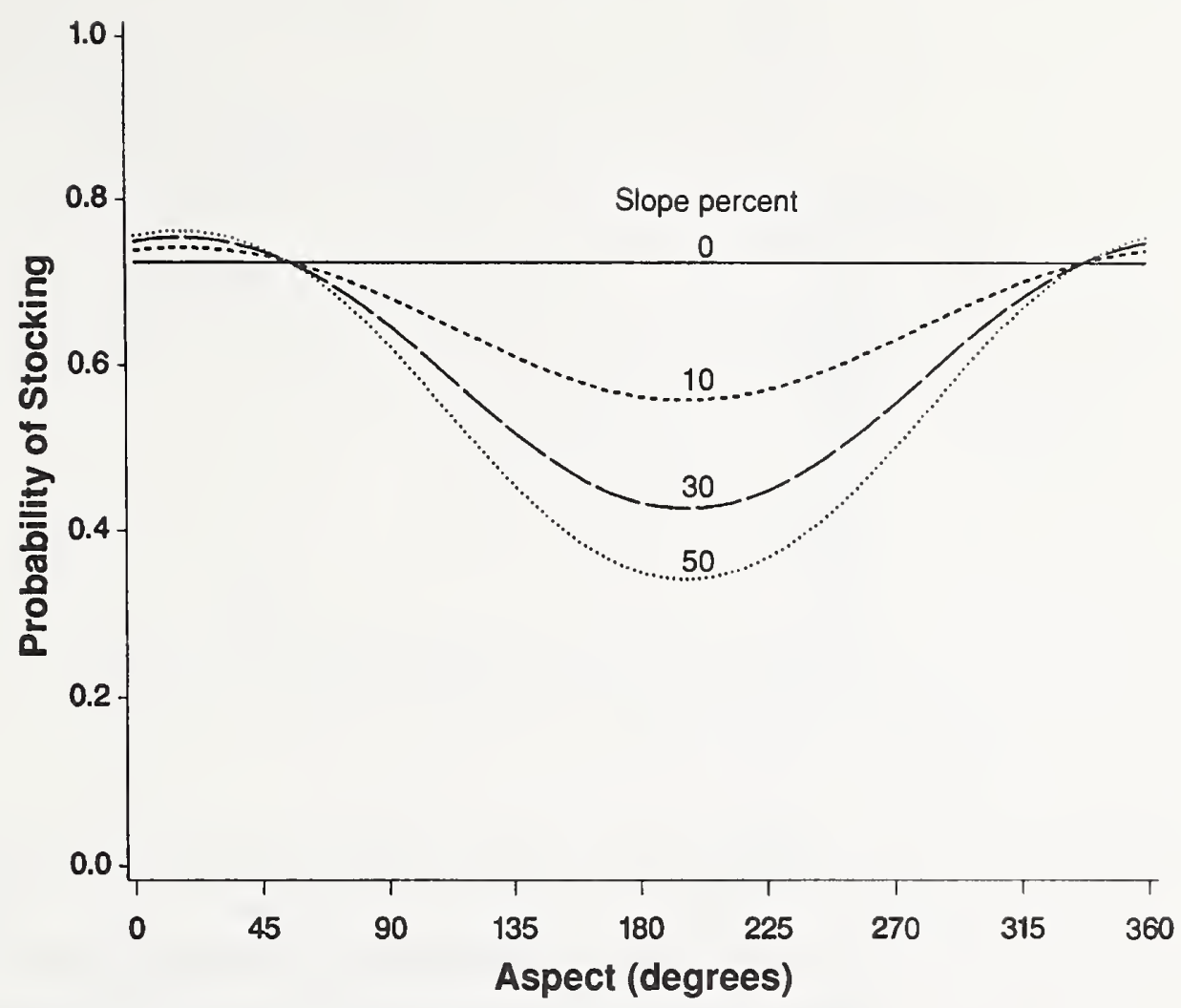

Figure 2-The effect of slope and aspect on predicted probability of stocking for an Abies grandis/Clintonia uniflora habitat type.

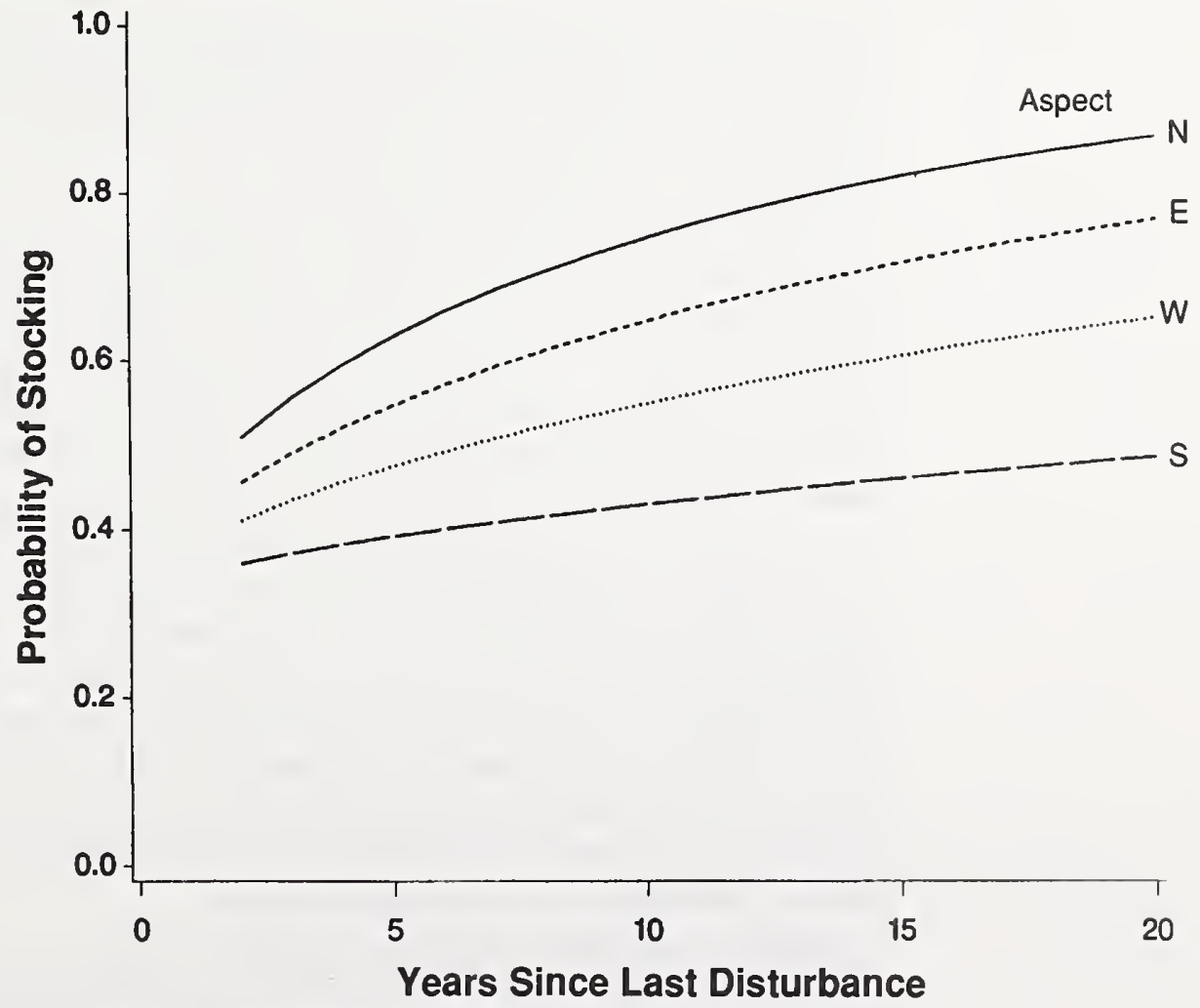

Figure 3-The effect of aspect and time on predicted probability of stocking for an Abies grandis/Clintonia uniflora habitat type. 


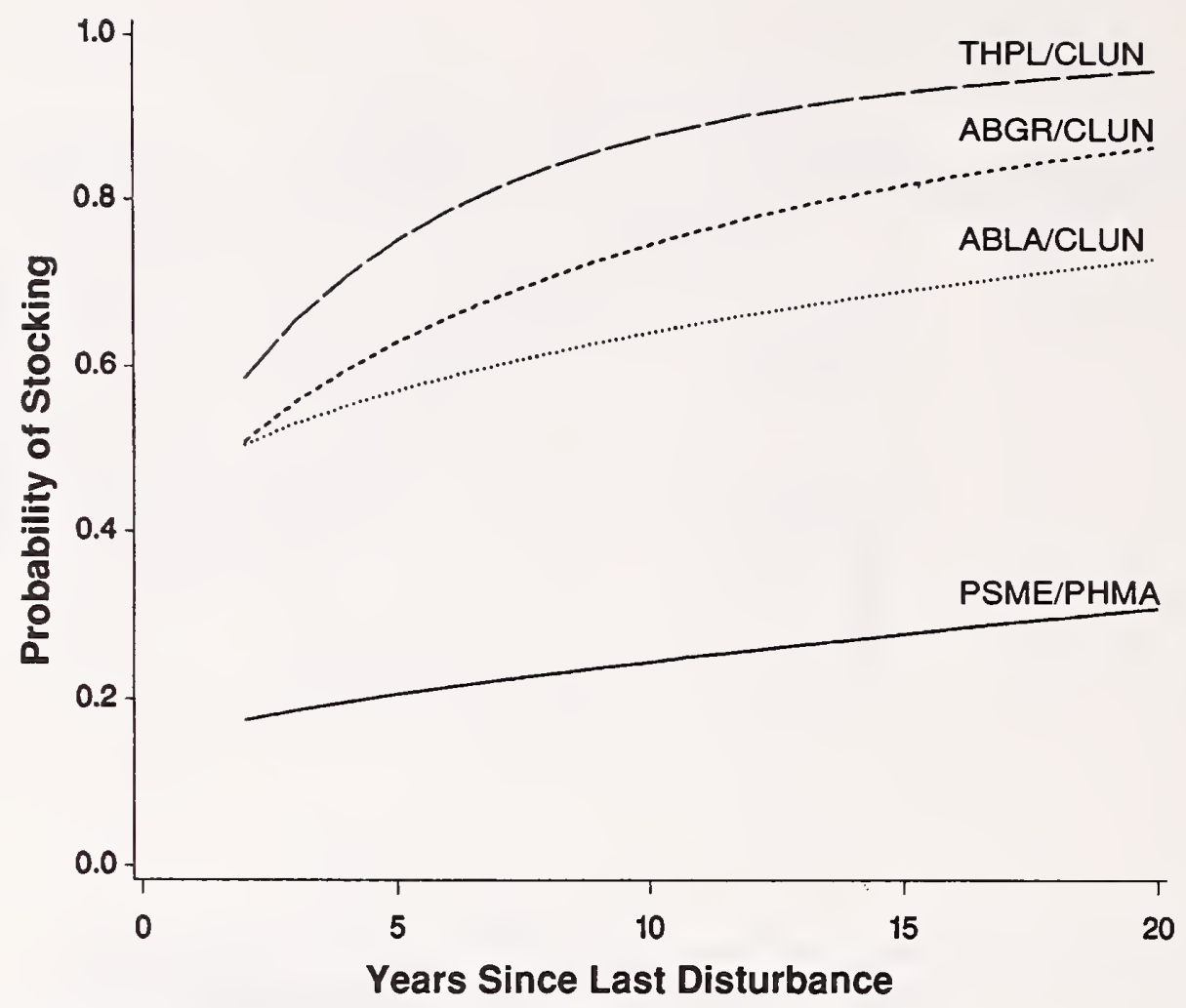

Figure 4-The effect of habitat type and time on predicted probability of stocking.

but never achieves as high a stocking level. The Abies lasiocarpa series has a lower rate of stocking than the Thuja/Tsuga and Abies grandis series and also does not achieve as high a stocking level. The Pseudotsuga menziesii series has the lowest stocking level and the lowest increases over time of all the series.

Elevation is another important independent variable. For the Abies grandis and Thuja/Tsuga series, the effect of elevation on the probability of stocking is quadratic (fig. 5). In the Thuja/Tsuga series, the optimum elevation is about 3,500 feet. The optimum elevation in the Abies grandis series is near 4,500 feet. The quadratic effect of elevation in the Abies grandis series is less than that in the Thuja/Tsuga series. In the Pseudotsuga menziesii series, increasing elevation decreases the probability of stocking. Elevation was not an important independent variable in the Abies lasiocarpa series.

The effect of residual overstory basal area on the probability of stocking changes with aspect and slope. The general trend of residual basal area on the probability of stocking for the Abies grandis and Thuja/Tsuga series is quadratic. On north aspects, optimum basal area decreases as slope increases (fig. 6). This means that a steep north-facing slope does not need as much shelter as a gentle north-facing slope. On south aspects, optimum basal area increases as slope increases (fig. 7). Steep south-facing slopes need more shelter than gentle south-facing slopes.

Residual basal area was not important in the equation for the Pseudotsuga menziesii series. In the Abies lasiocarpa series, the natural log of residual basal area was significant, meaning that the probability of stocking increases rapidly as basal area increases at low densities, but there is little additional effect as basal area gets progressively more dense. 


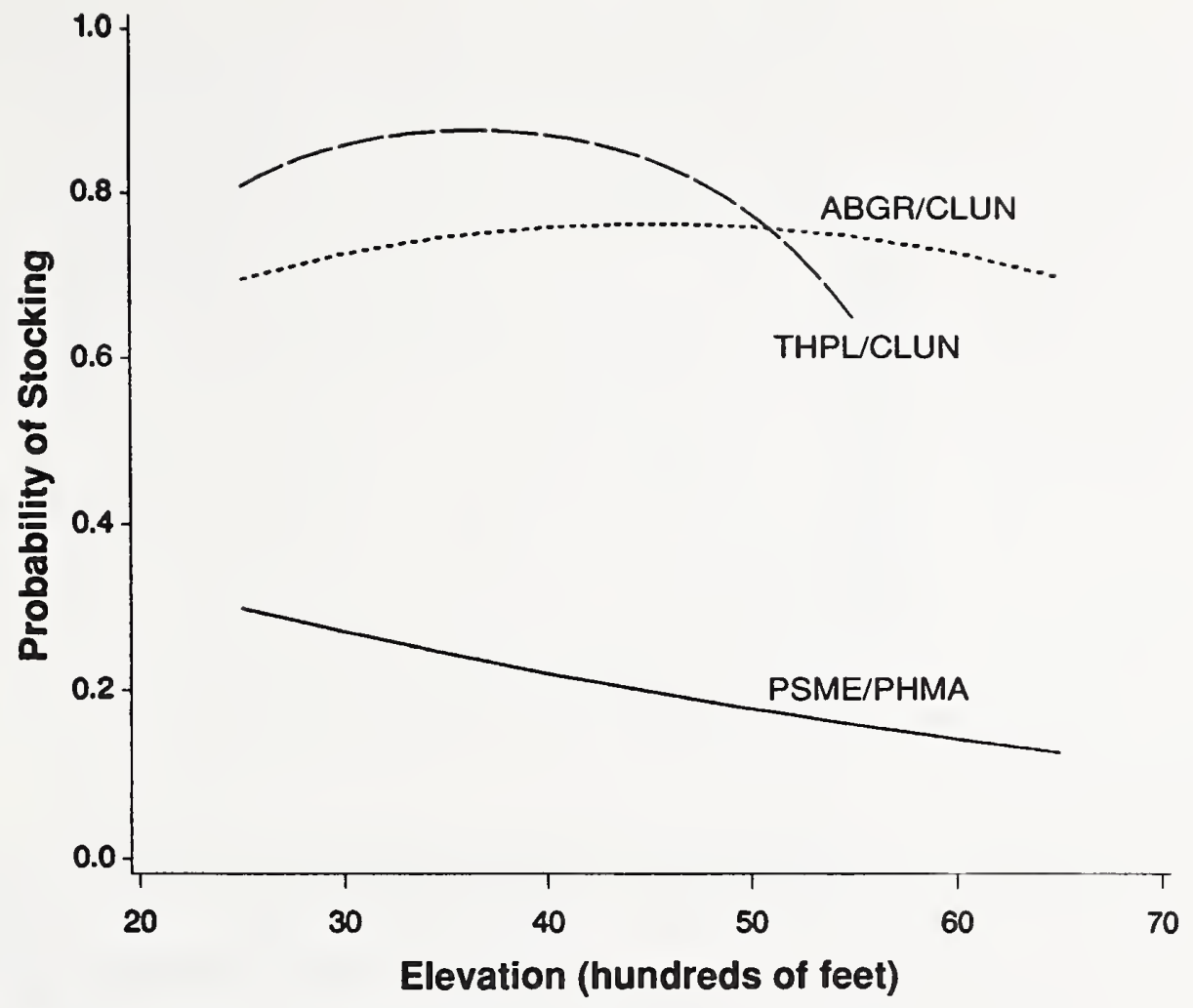

Figure 5-The effect of elevation and habitat type on predicted probability of stocking.

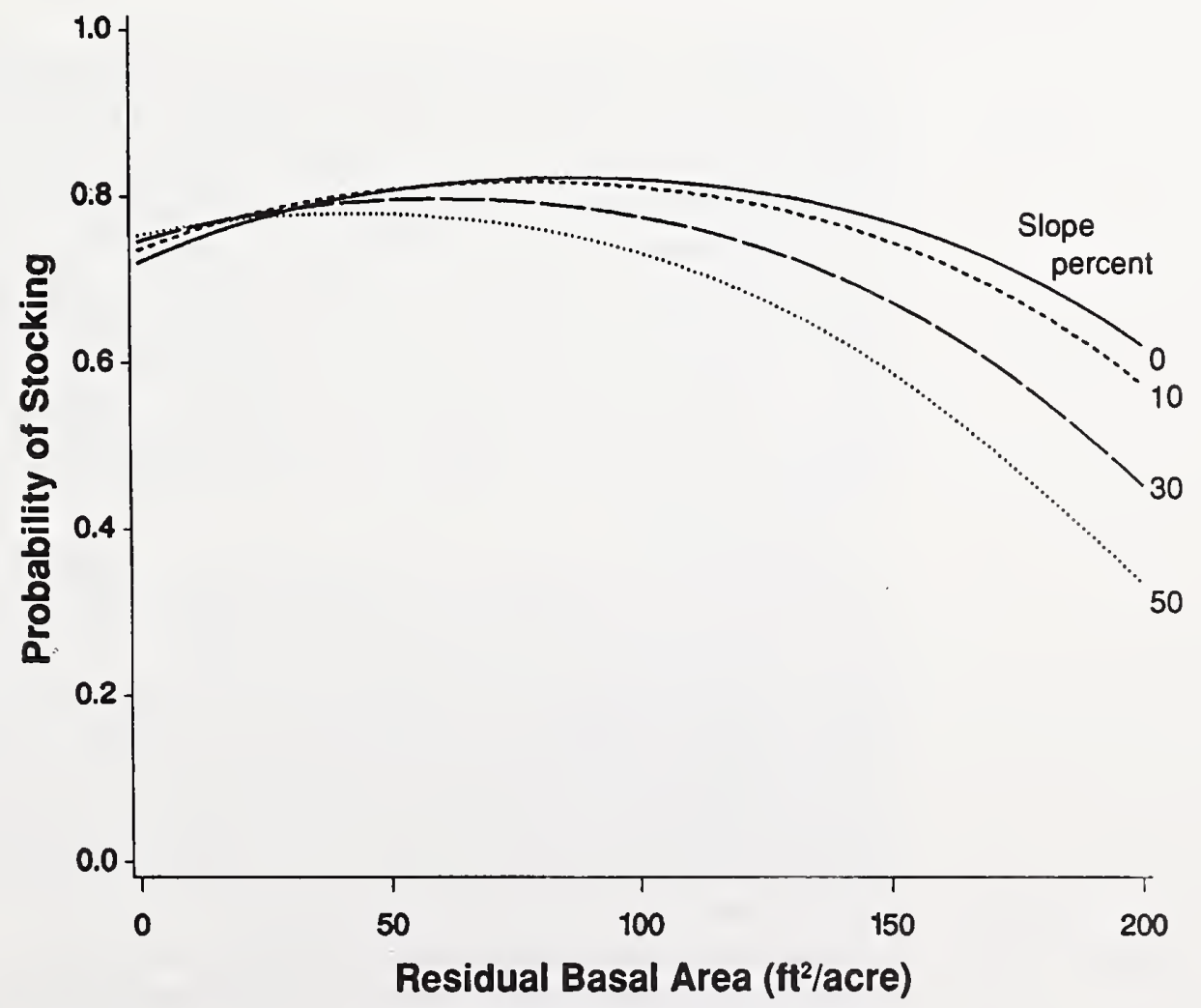

Figure 6-The effect of residual overstory basal area and slope for a north aspect on predicted probability of stocking for an Abies grandis/Clintonia uniflora habitat type. 


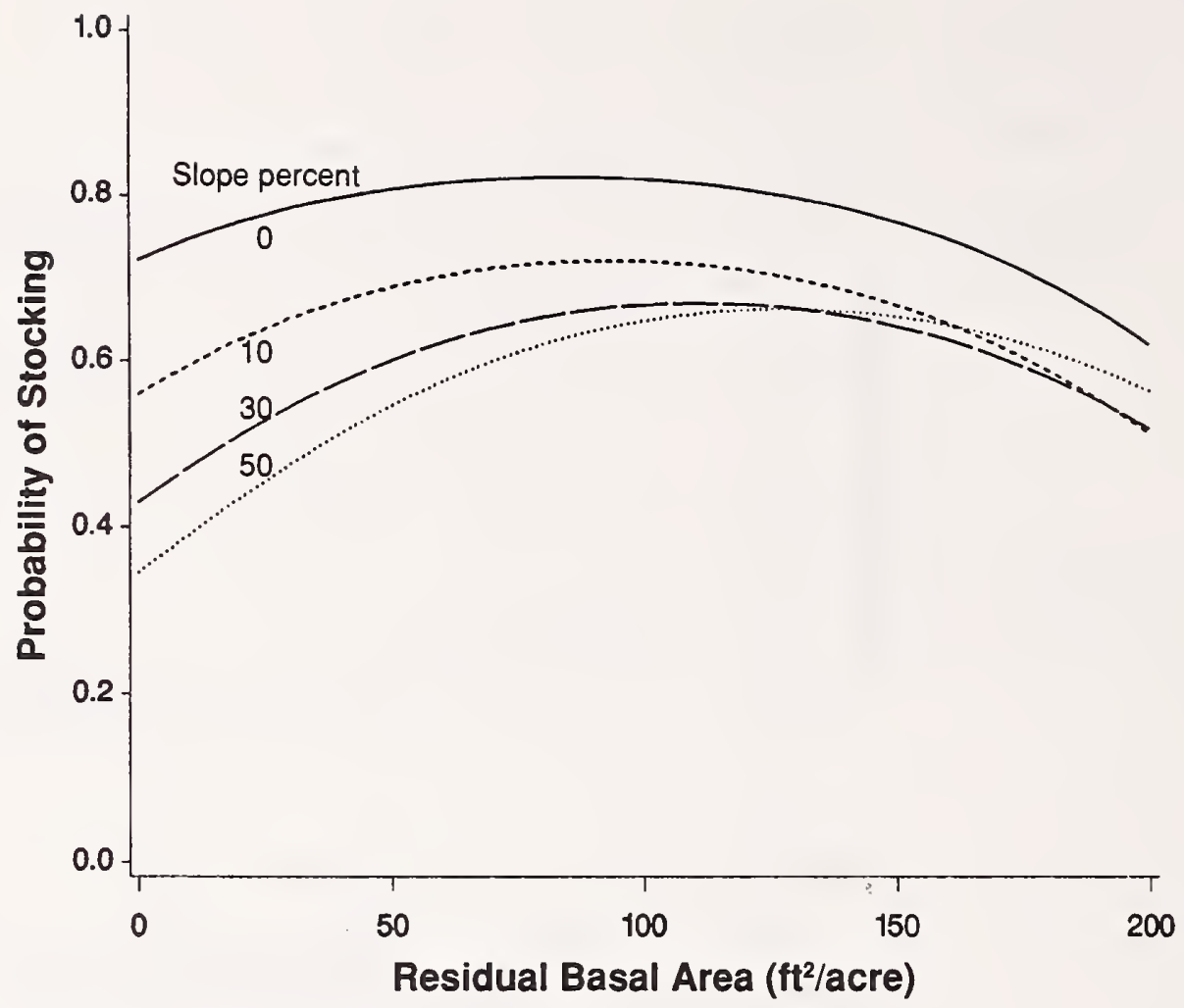

Figure 7-The effect of residual overstory basal area and slope for a south aspect on predicted probability of stocking for an Abies grandis/Clintonia uniflora habitat type.

The effect of western spruce budworm on the probability of stocking is not very dramatic. This is not surprising since nonhost species stock plots as do budworm host species. Lower rates of stocking over time occurred in the Pseudotsuga menziesii, Thuja/Tsuga, and Abies lasiocarpa series, but not in the Abies grandis series. Additionally, budworm defoliation in the 5 years prior to harvest significantly decreased the probability of stocking in the Abies lasiocarpa series. Figure 8 illustrates the probability of stocking over time on the Pseudotsuga menziesii series. The upper line has no budworm. The lower line illustrates the probability of stocking if budworm defoliation occurred every year. After 20 years, the difference in the probability of stocking is 0.07 .

Coefficients for spruce budworm effects in appendix B are sometimes not significant at the 0.05 level. Budworm defoliation reduces the rate of stocking of host species; it does not prevent stocking. For example, in the equation for the probability of stocking for Pseudotsuga menziesii series (appendix B, table 9), the coefficient for SQBWAF is 0.12913 (nonsignificant), and the coefficient for SQREGT is 0.21368 (significant). The effect of these two variables is to break the number of years since disturbance into two components: a significant increase when there is no budworm defoliation and a nonsignificant increase when there is budworm.

Figure 9 illustrates the concepts of optimum aspect and amplitude. Both are calculated from the interaction of slope and aspect using procedures developed by Stage (1976). The mathematical determination of the highest and lowest points along the curve indicates the general directions of the optimum 


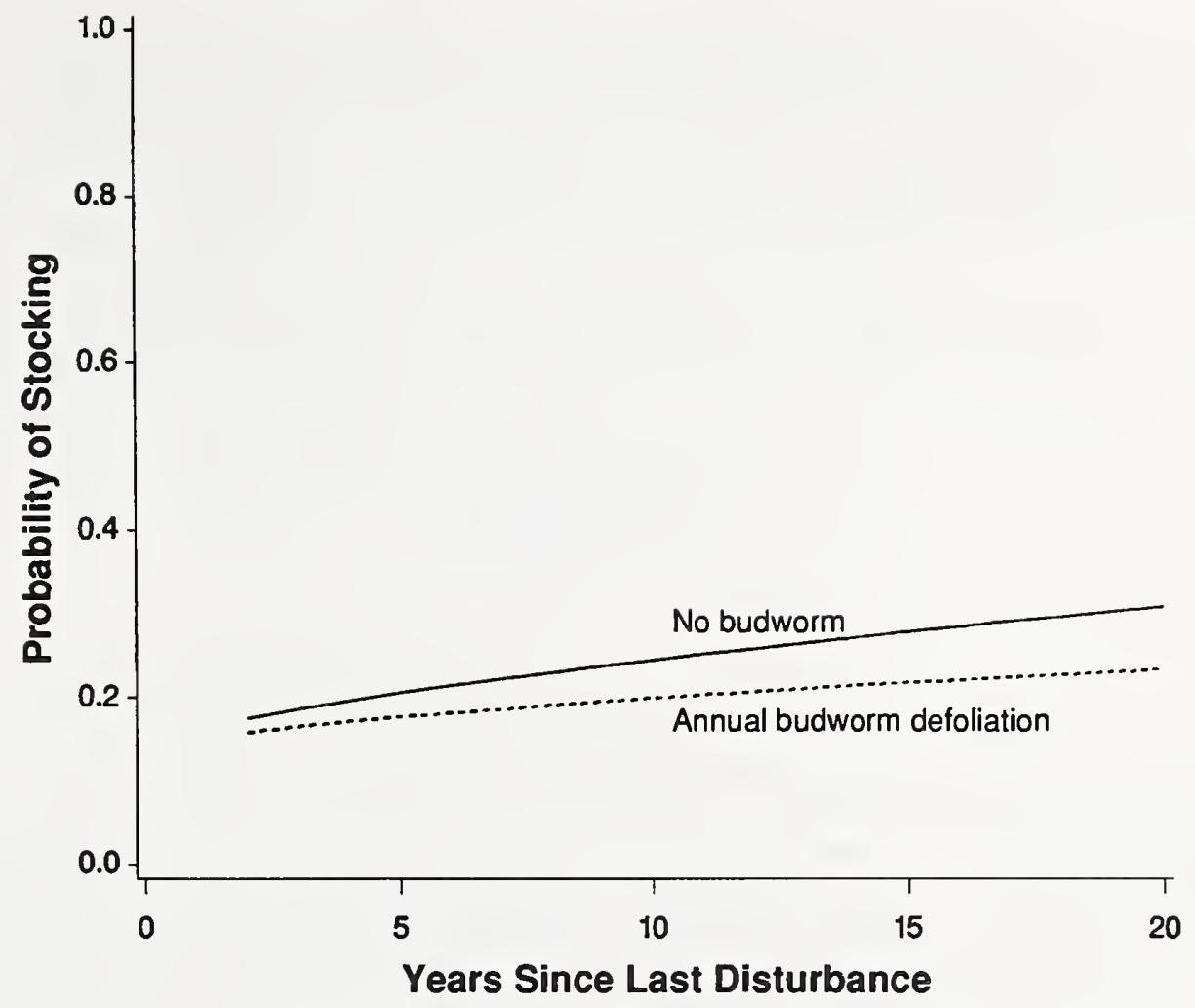

Figure 8-The effect of western spruce budworm and time on predicted probability of stocking for a Pseudotsuga menziesiil Physocarpus malvaceus habitat type.

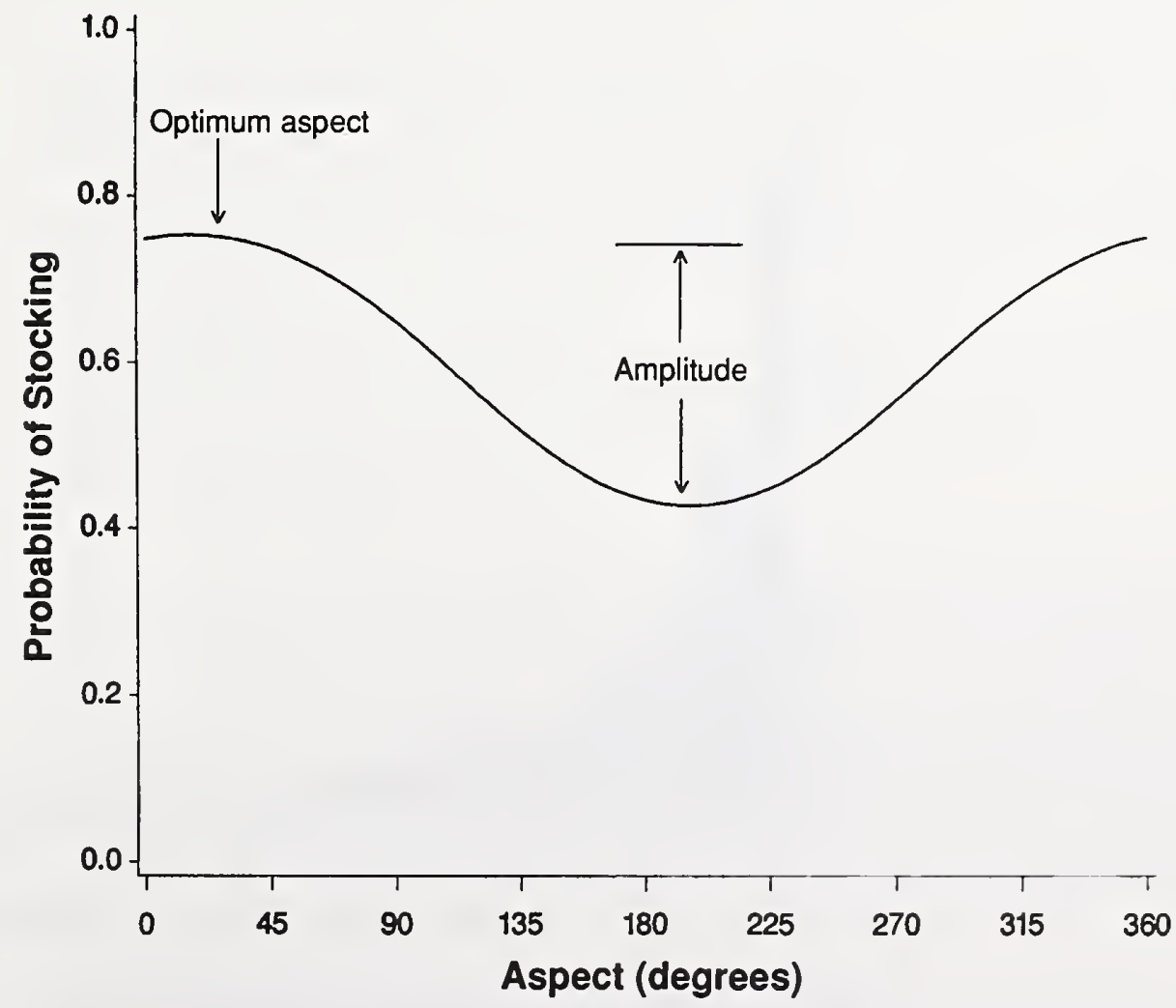

Figure 9-Illustration of optimum aspect and amplitude for the probability of stocking. 
Number of Trees per Stocked Plot and poorest aspect for the dependent variable being predicted. The optimum aspect is the aspect with the highest point along the curve. In figure 9 it is 17 degrees-indicating a general direction of north to northeast for the highest probability of stocking for the Abies grandis/Clintonia uniflora habitat type. The poorest aspect is 180 degrees from the optimum aspect.

Amplitude is the depth of the curve from the optimum aspect to the poorest aspect. The larger the amplitude, the larger the difference between the optimum and poorest aspects. Amplitude can be calculated using any slopewe use 30 percent throughout this paper. The amplitude shown in figure 9 is 0.34 . This means the probability of stocking differs by 0.34 between the optimum and poorest aspects for a 30 percent slope.

There is another important point about the calculation of amplitude when the form of the equation is

$$
P=\left(1+e^{-\left(\Sigma \beta_{i} X_{i}\right)}\right)^{-1}
$$

Amplitude is calculated with the curve centered on a probability of 0.5 . Since probabilities are asymptotic to 0.0 and 1.0 , amplitudes are at their maximum at a probability of 0.5 .

Analysis of data now excludes nonstocked plots. Given that a plot is stocked, we are interested in predicting how many trees are established, species composition, and seedling heights. Distribution of the number of trees on stocked plots is shown in figure 10. The highest percentage is for plots that have 1 tree, followed in decreasing order by $2,3,4$, and so on, up to 213 trees per plot. The result is a reversed $\mathrm{J}$-shape distribution.

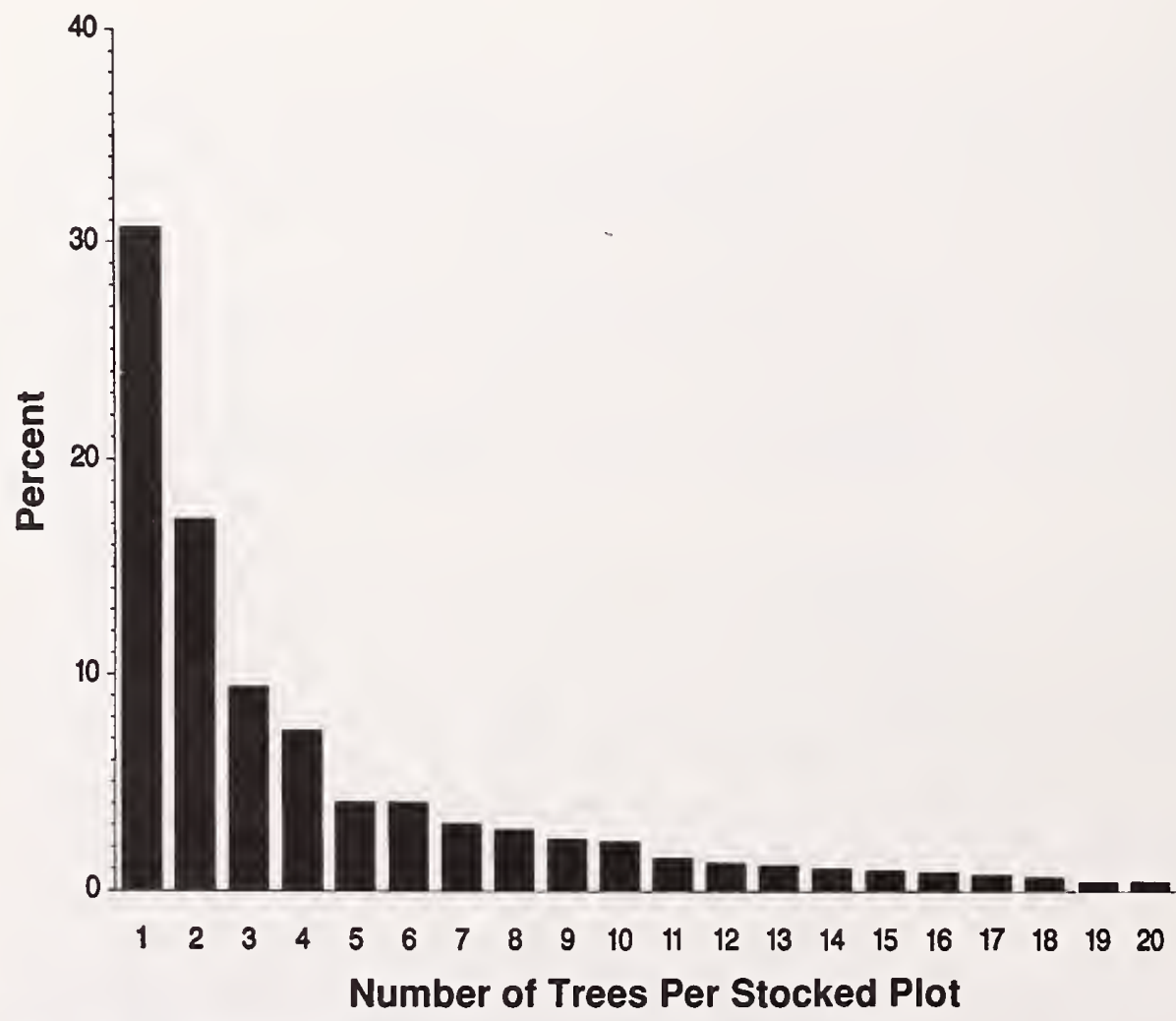

Figure 10-Distribution of the number of regeneration-size trees per stocked plot. The tail of the distribution continues past 20 trees up to 213 trees on a plot. 
The distribution of trees per plot is the important variable to reproduce, rather than the mean. Predictions of mean values with linear regression would not properly simulate the natural occurrence of regeneration because the categories with the highest probability of occurrence would seldom be predicted. Another method that simulates the distribution of the number of trees per plot is used.

A two-step analysis was used to develop a Weibull cumulative density distribution equation. First, the data were categorized as follows:

4 Habitat type series (Pseudotsuga menziesii, Abies grandis, Thuja/Tsuga, and Abies lasiocarpa)

$\mathrm{X} 4$ Aspects (north \pm 45 degrees, east, south, and west)

$\mathrm{X} 3$ Time periods (2-7 years since last disturbance, 8-12 years, 13-20 years)

$\mathrm{X} 2$ Budworm defoliation histories ( 0 -2 years, $\geq 3$ years).

Of the possible 96 categories, 73 had adequate data ( $\geq 25$ plots). A Weibull equation was developed for each category, yielding 73 estimates of $B$ and $C$ for equation 2 . Averages of variables by category were also calculated-average aspect, average slope, and so on.

The second step in the analyses used linear regression to estimate Weibull parameters $B$ and $C$ as a function of site conditions. The resulting equations are shown in appendix B, table 10 . Slope, aspect, elevation, habitat type series, number of years without budworm defoliation, and number of years with budworm defoliation are important predictors of the $B$ parameter. For the $C$ parameter, important predictors are elevation, number of years without budworm defoliation, and number of years with budworm defoliation.

Number of Species per Stocked Plot

\section{Probability of Advance Regeneration}

It is necessary to predict the number of species on stocked plots because all species do not occur on a given $1 / 300$-acre plot. This distribution has a reversed $\mathrm{J}$-shape as shown in figure 11 . The highest percentage is for 1 species, followed in decreasing order by $2,3,4,5,6$, and 7 species. Seven species on a $1 / 300$-acre plot occurred only once. Separate equations were developed to predict the probability of $1,2,3,4,5$, and 6 species on stocked plots. Coefficients are given in appendix B, table 11 .

Prediction of the number of species on a stocked plot is conditional on the number of trees on the plot. For example, one tree on the plot could only result in one species on the plot; two trees, two or fewer species; three trees, three or fewer species; and so on.

Advance regeneration is defined as best trees that germinated more than 3 years prior to the year of harvest. Advance regeneration is commonly found beneath the canopy of mature stands in the Northern Rocky Mountains. Many of these trees survive harvest, site preparation, and the sudden exposure to more sunlight. Advance regeneration was included in the model as a separate class of regeneration so that future refinements to the Prognosis Model can account for growth response to release, important disease interactions with suppressed regeneration, and so on. Equations to predict the probability of advance regeneration were developed by species; coefficients are given in appendix B, table 12 .

The occurrence of advance regeneration is related to shade tolerance of the species. Shade-intolerant species have lower probabilities than shadetolerant species. Occurrence is also related to the relationship of species to 


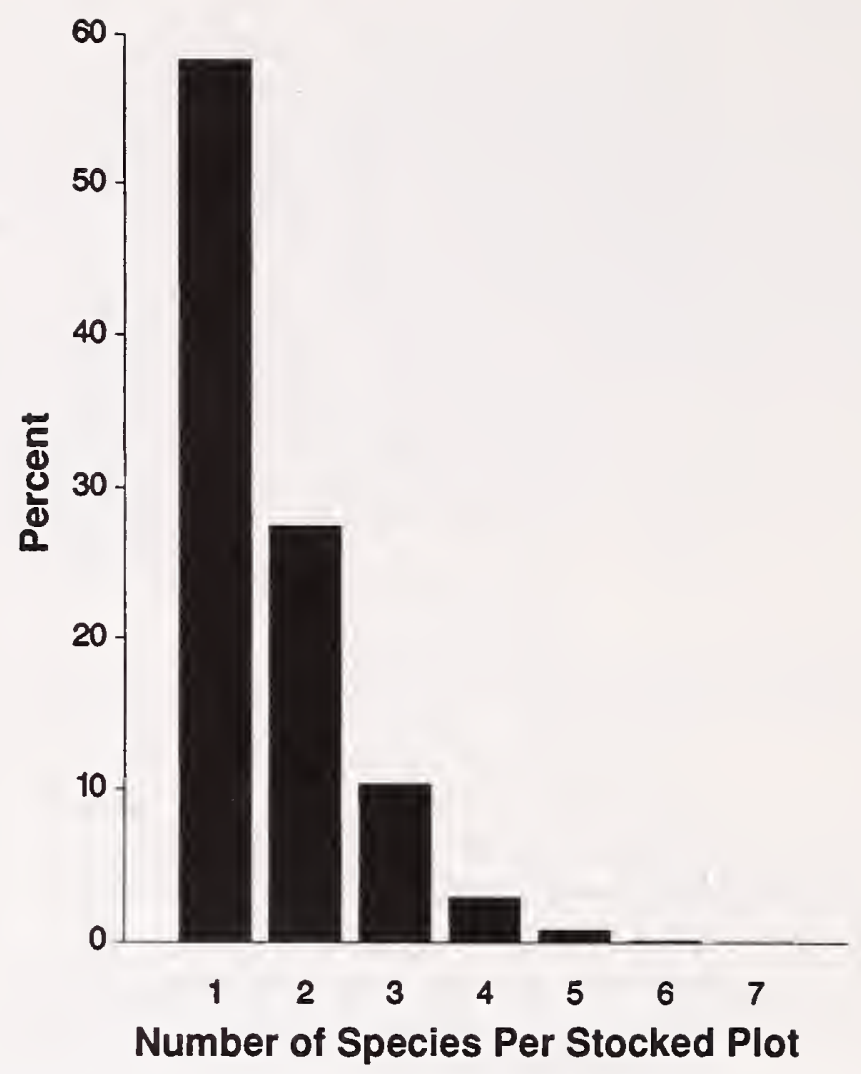

Figure 11-Distribution of the number of species per stocked plot.

Probability of Subsequent Regeneration habitat type. For example, Douglas-fir is considered shade tolerant on habitat types where it is the climax species, but is shade intolerant where it is not a climax species.

Mechanical or burn site preparation generally decreases the probability of advance regeneration, with burn site preparation decreasing the probability more than mechanical. Because this study was retrospective, we could not determine whether advance regeneration was deliberately destroyed or whether none was present and site preparation was done to increase subsequent regeneration success.

The probability of advance regeneration decreases over time. This could be due to mortality over time or poor response to release. Trees that respond poorly to release could, with time, become subordinate to a subsequent tree of the same species.

Trees up to 3 years old at the time of harvest were recorded as subsequent regeneration. This was for four reasons. First, there could be some error in aging small trees; accuracy was \pm 1 year. Second, the year of harvest entered on historical records was usually the year of completion and, if it took more than 1 year to harvest the stand, some areas would have been harvested before others. Third, a 3-year-old tree would not have suffered major physiological setbacks from suppression by overstory trees. Fourth, any trees planted immediately after harvest would appear to be advance regeneration.

Equations for the probability of subsequent best trees are given in appen$\operatorname{dix} B$, table 13. The occurrence of subsequent regeneration differs from that for advance regeneration. Mechanical or burn site preparation increases 


\section{Probability of Excess Regeneration}

\section{Heights of Regeneration}

subsequent regeneration over untreated plots. In general, coefficients for mechanical and burn site preparation are also larger for shade-intolerant species versus shade-tolerant species.

The number of years since last disturbance increases the probability of subsequent species. The rate of increase for plots with spruce budworm defoliation is less than for plots without defoliation for three host species-Douglas-fir, grand fir, and subalpine fir. Spruce budworm defoliation in the 5 years prior to harvest also decreases the probability of subsequent grand fir.

Residual overstory basal area decreases the probability of subsequent regeneration for every species except western hemlock. And if the species left in the overstory is the same one being predicted, the probability of subsequent regeneration is significantly increased for all species.

Excess regeneration is all regeneration not chosen as best trees on the plot. The presence of an excess tree of a species is conditional on a best tree of the same species being established on the plot. Excess trees are distributed quite differently from best trees. Species that become established at high densities have a larger proportion of excess trees than do species that become established at low densities. For example, grand fir and western hemlock often overstock plots on the Tsuga heterophylla habitat type series.

A consistently important independent variable increasing the probability of excess regeneration is the same species in the overstory (appendix B, table 14). The largest coefficient is for lodgepole pine and the smallest is for grand fir.

Equations predicting heights of regeneration were developed for advance best trees, subsequent best trees, and excess trees. Various combinations and transformations of dependent and independent variables were tried. For advance and subsequent regeneration, the best dependent variable was always the natural log of tree height. Heights of excess trees are determined from Weibull distributions.

Equations for heights of advance and subsequent best trees use tree age as an independent variable. This necessitates determination of tree age at the end of the Prognosis Model cycle. Weibull equations were developed that represent the distribution of the number of years from harvest to germination of established seedlings. This is a negative value for advance regeneration and a positive value for subsequent regeneration. Once "delay to germination" is known, tree age can be calculated.

Heights of Advance Regeneration-Weibull distributions for choosing the delay to germination for advance best trees are given in appendix B, table 15. Delay to germination is dependent on species, residual overstory basal area, and spruce budworm defoliation during the 5 years before harvest. Age is the number of years from germination to the end of the Prognosis Model cycle. Once tree age is determined, equations given in appendix B are used to predict tree heights.

A total of 5,648 advance best trees were used to develop the height equations in appendix B, table 16 . Age is the single most important predictor of tree height. The coefficient for age is positive for all species; however, these coefficients are not as large as those for subsequent species. This is because the advance trees were suppressed prior to the harvest.

Amplitude values for regeneration heights given in appendix B, tables 16 and 18, are interpreted differently than the amplitude values in probability equations. For tree heights, amplitude is tree height at the optimum aspect 
divided by tree height at the poorest aspect. For example, an amplitude of 1.82 for advance lodgepole pine means that trees will be 1.82 times taller at the optimum aspect of 31 degrees than they are at the poorest aspect of 211 degrees.

Heights of Subsequent Regeneration-The calculation of heights for subsequent regeneration begins by determining the number of years from the last disturbance to seedling germination. Coefficients for these Weibull distributions are given in appendix $\mathrm{B}$, table 17 . Important variables are the number of years since last disturbance, spruce budworm defoliation after harvest, and species.

Figure 12 shows cumulative Weibull distributions for the number of years of delay to seedling germination for plots 2-7, 8-12, and 13-20 years since disturbance. The species illustrated is grand fir with no budworm defoliation.

Equations for predicting heights of subsequent best trees are given in appendix B, table 18. A total of 9,239 subsequent best trees were used in these analyses. As with advance regeneration, the most important independent variable is tree age.

Spruce budworm defoliation history was not important for predicting height of host species. This finding agrees with Carlson (1988), who found that height growth of subsequent regeneration in even-age stands was not affected by spruce budworm and defoliation was light, even though adjacent overstory host trees were moderately to heavily defoliated.

Increasing residual overstory density reduced heights for all species. Shadeintolerant species, such as ponderosa pine and lodgepole pine, had large

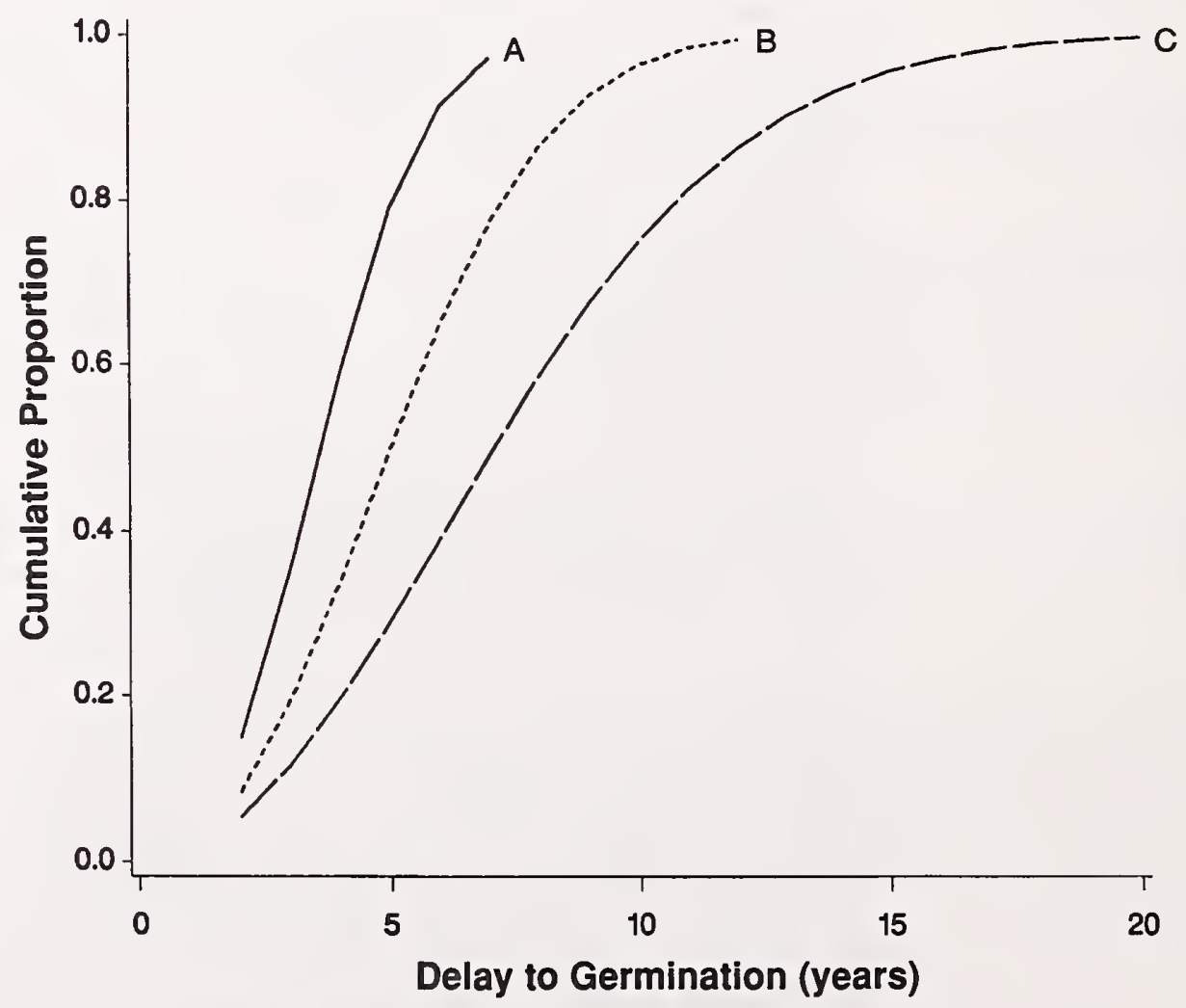

Figure 12-Weibull cumulative frequency distributions for delay to germination for subsequent grand fir regeneration. Curve $A$ is for 2-7 years time since disturbance, curve $B$ for $8-12$ years, and curve $C$ for $13-20$ years. 
negative coefficients, while shade-tolerant species, such as western redcedar and western hemlock, had smaller negative coefficients.

Site preparation increased heights for most of the shade-intolerant subsequent species, but had no effect or a negative effect on shade-tolerant subsequent species.

Heights of subsequent regeneration increased as the number of trees on the plot increased. This seems counter-intuitive, because increasing competition should decrease tree growth. However, increasing seedling density could indicate better microsites.

Heights of Excess Regeneration-Heights of excess trees were not measured in the field. However, a height must be assigned to all tree records being passed to the Prognosis Model. Two things are known about excess trees. First, an excess tree cannot be taller than the best tree of the same species on the plot. Second, an excess tree is at least as tall as the minimum establishment height listed in table 1.

Rather than assume a linear relationship between minimum establishment height and height of the tallest tree of the same species on the plot, Weibull distributions were developed for the heights of best trees. These distributions were used to define the shape of the distribution for heights of excess trees. Coefficients are given in appendix B, table 19. Important variables for the distributions are species and years since last disturbance.

\section{HOW THE PROGNOSIS MODEL AND REGENERATION MODEL INTERACT}

The Prognosis Model is an individual-tree, distance-independent forest growth and yield model. Originally developed for northern Idaho and adjacent forests in Montana and Washington (Stage 1973; Wykoff and others 1982), the Prognosis Model has been calibrated for other forest regions. Geographic versions of the Prognosis Model are called variants.

An inventory of trees from one or more plots represents a stand in the Prognosis Model. The inventory is maintained in a tree list where attributes of inventoried trees are kept-d.b.h., height, species, and so on. One of the attributes in the tree list is the number of trees per acre each tree represents. The trees per acre represented by a tree is initially a function of the inventory plot size and the number of plots sampled in the stand. Each tree sampled on a 1-acre plot represents 1.0 trees per acre, each tree sampled on two 1-acre plots represents 0.5 trees per acre, each tree sampled on ten $1 / 300$-acre plots represents 30 trees per acre, and so on.

The Prognosis Model projects the increment of individual trees over time. Time steps in the Prognosis Model are called cycles-cycles can vary in length, the default being 10 years. Prognosis Model harvests and thinnings, if any, are done at the beginning of the cycle; then growth and mortality are predicted for each tree. Each tree receives a predicted increment in d.b.h. and height as well as a change in crown ratio. Mortality is simulated as a reduction in the trees per acre that the tree represents in the stand.

Plot attributes that change are updated at the end of the cycle for reporting purposes and for use by other submodels of the Prognosis Model; for example, plot overstory density and plot overstory species composition. The regeneration model makes extensive use of plot information.

Use of the regeneration model can be scheduled at the end of any Prognosis Model cycle. The regeneration model uses the updated inventory to predict 
Step 1: Initiate Regeneration Model

Step 2: Determine Plot Site Preparation regeneration that occurs during the cycle. The new trees are added to plots that correspond to the inventory plots in the Prognosis Model. The use of plot information provides some spatial resolution to the regeneration model because each plot can have unique attributes such as slope, aspect, habitat type, site preparation, overstory density, and overstory species composition.

New regeneration is added to the Prognosis Model tree list at the end of the cycle in what is called a regeneration tally. A tally of regeneration is similar to the results of taking a regeneration survey for a stand; the regeneration process continues for a number of years before it is quantified by a regeneration survey.

The regeneration period is the number of years during which regeneration becomes established as a result of a disturbance. For modeling purposes, the regeneration period is set at 20 years. Any time there is a Prognosis Model cycle boundary during the 20 years of a regeneration period, the regeneration model will be invoked to predict new regeneration. Multiple tallies during these 20 years are called a tally sequence.

Regeneration that occurs after the regeneration period is called ingrowth. Ingrowth is both the result of succession by shade-tolerant species and the continued regeneration of trees into gaps in the tree canopy.

\section{STEPS IN THE REGENERATION MODEL}

The computer steps for the regeneration model are depicted in figure 13. The computer code is written in FORTRAN. Each step is briefly described in this section.

The regeneration model is invoked at the end of a Prognosis Model cycle. At this point in the Prognosis Model, silvicultural prescriptions for the cycle have been implemented, growth has been predicted, mortality has been accounted for, and plot/stand statistics have been updated.

Before the regeneration model is invoked, the tree list is checked to ensure the tree list has enough space to hold new records. Space is provided by compressing the tree list. This feature of the Prognosis Model combines similar tree records as discussed by Wykoff (1986).

In the regeneration model, computer storage is allocated and prepared for use. Plot replication, if needed, is done at this time. Plot replication ensures there are an adequate number of plots (default $=50$ ) to dampen the stochastic effects of any one plot on the projection. The effect is to predict regeneration closer to the mean expectation. Fifty plots are enough to average out the effects of unusual events, yet is still efficient use of computer time. Model users can change the default minimum number of plots to as few as 20 .

Each plot is assigned a site preparation-mechanical, burn, or untreated. The percentages of site preparations are either specified by the user or are determined from default equations derived from the data. User-specified percentages take precedence over default equations. Once percentages are determined, site preparations are assigned at random to the plots.

Users have two ways to assign site preparations to specific plots. Site preparation can be coded on the inventory records, or it can be specified on special computer records at the time the Prognosis Model is initiated (see Ferguson and Crookston 1991). A category for roads is included. Road site preparation is all road cuts, all road fills, and unmaintained roadbeds. 


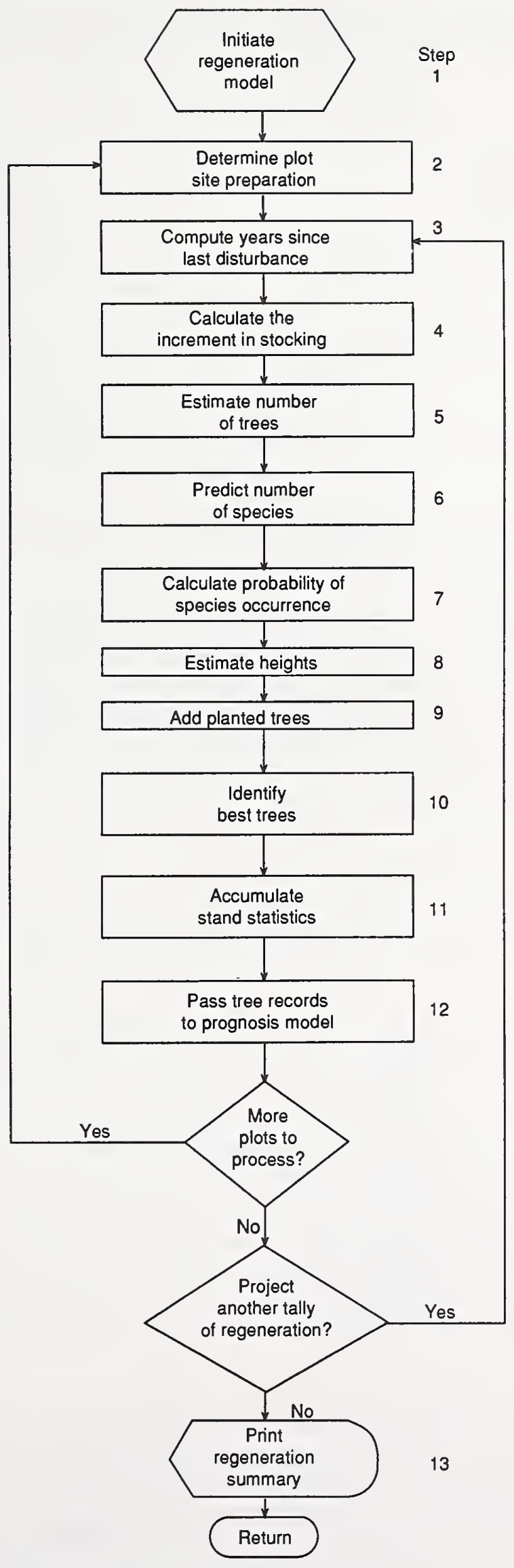

Figure 13-Steps in the Regeneration Establishment Model. 
Step 3: Compute Years Since Last Disturbance

\section{Step 4: Calculate the Increment in Stocking}

For each plot, the number of years since last disturbance is computed-the result is dependent on the method of site preparation. Untreated plots were last disturbed at the time of harvest. Mechanically disturbed plots were last disturbed at the time of mechanical site preparation, and burned plots were last disturbed at the time of burning.

The increment in stocking is the increase in the probability of stocking from one time period to another. Figure 14 illustrates the increment in the probability of stocking for successive time periods of $5,10,15$, and 20 years. The number and length of time periods can be altered by controlling cycle lengths in the Prognosis Model. Whenever there is a cycle boundary in the Prognosis Model and a disturbance has occurred in the previous 20 years, a regeneration tally will be predicted by the regeneration model.

A calibration feature in the regeneration model is invoked when the stand inventory is taken within 20 years of a requested tally of regeneration. Calibration adjusts the probability of stocking curve to coincide with the actual inventory at the time the inventory was taken. Then the increment in stocking from the time of inventory to the end of the cycle boundary is calculated. Details of the calibration feature are explained in a later section.

The number of trees per plot is conditional on the plot being stocked. In the first tally of a tally sequence, the number of trees on the plot is determined from Weibull cumulative distribution functions developed from the data. A uniformly distributed pseudo-random number is used to choose the actual number of trees from Weibull distributions. The number of trees is rounded to the nearest integer.

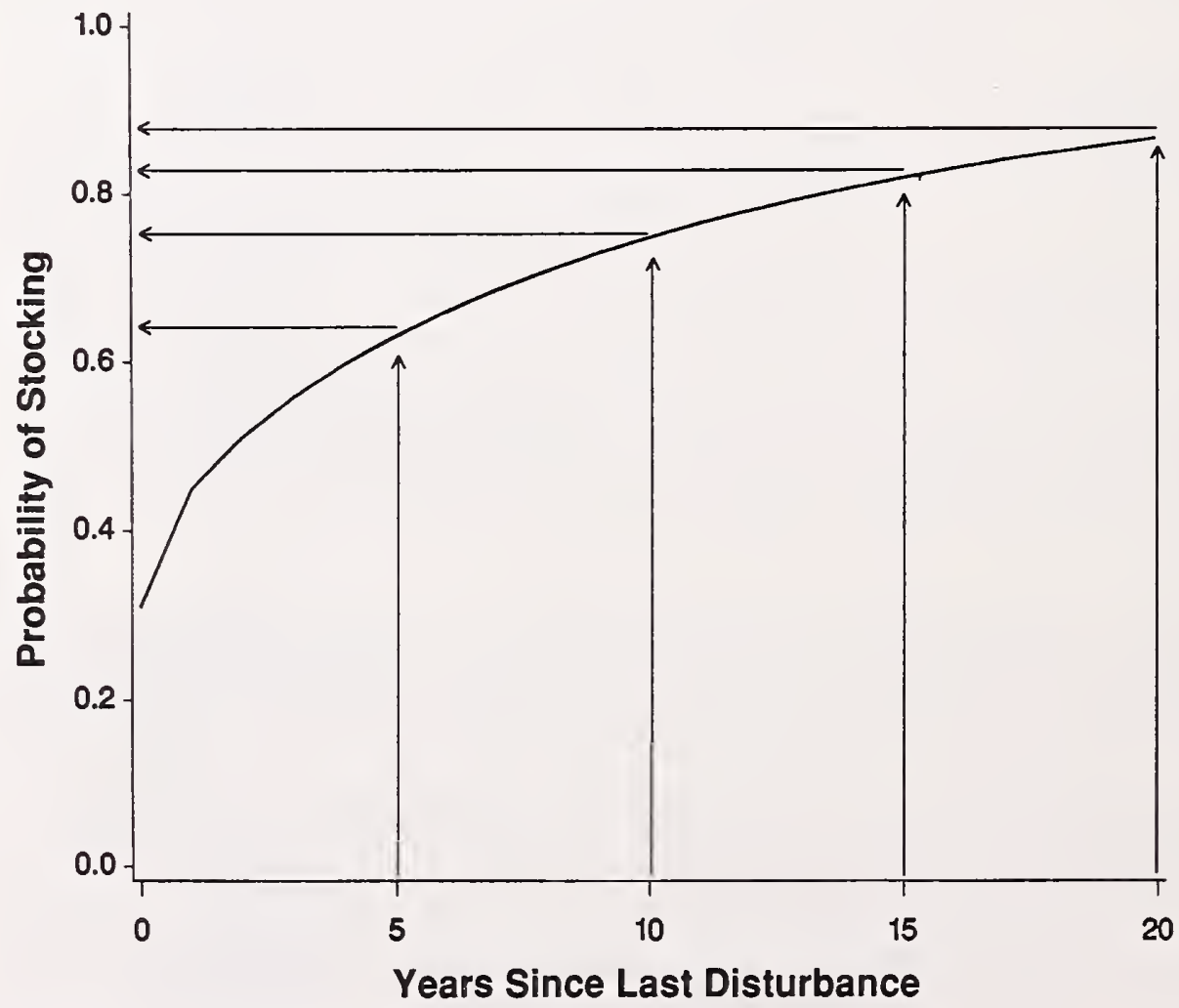

Figure 14-Increments in probability of stocking at 5, 10,15, and 20 years time since disturbance. 


\section{Step 6: Predict Number of Species}

\section{Step 7: Calculate Probability of Species Occurrence}

\section{Step 8: Estimate Heights}

Step 9: Add Planted Trees
For other tallies of a tally sequence, only the incremental number of trees becoming established on the plot during that time period is added to the tree list.

The number of species is also conditional on the plot being stocked. Logistic regression equations predict the probability of $1,2,3,4,5$, and 6 species on the plot. The number of species cannot exceed the number of trees chosen in step 5.

A uniformly distributed pseudo-random number is used to make a discrete, but unbiased, choice of the number of species on the plot. The probabilities for each number of species are calculated and totaled. The total is divided back into the probabilities so that the sum of the probabilities equals 1.0. The adjusted probabilities are accumulated within the interval $[0,1]$, and a uniformly distributed pseudo-random number is compared to the accumulated probabilities. The number of species on the plot is the one for which the accumulated probability first exceeds the pseudo-random number.

There are 10 species in the regeneration model and each can occur in any of three ways: as advance best trees, as subsequent best trees, and as excess regeneration. Advance trees germinated more than 3 years prior to the harvest date. Subsequent trees germinated after the cutoff date for advance trees. Excess trees were established on the plot, but were not aged.

First, the probabilities of advance and subsequent best trees are predicted by species (probabilities can be 0.0 when certain species do not occur on some habitat types or in some geographic locations). The advance and subsequent distributions are accumulated within the interval $[0,1]$, and pseudo-random numbers are used to choose the same number of species on the plot as was chosen in step 6.

Next, the probability of excess regeneration is predicted by species. Species of remaining trees on the plot are determined from the excess distribution. Probabilities in the excess regeneration distribution can differ considerably from the combined advance and subsequent distribution.

Heights of best trees are predicted from linear regression equations. Separate equations were developed by species for advance and subsequent best trees.

Heights are predicted for each best tree on the plot. Tree heights are varied by adding or subtracting a random proportion of the standard error of the estimate to predicted tree height. A pseudo-random number determines whether to add or subtract. A second pseudo-random number in the interval $[0,1]$ determines the proportion of the standard error to add or subtract.

Excess tree heights are determined from Weibull cumulative distribution functions that were developed from the heights of best trees. A pseudorandom number is used to assign heights for excess trees between the minimum establishment height and the height of the best tree of the same species on the plot.

The regeneration model predicts natural regeneration. Planted trees are an addition to predicted natural regeneration. Model users specify species, density, year of planting, and survival of planted trees. The default option is for trees to be planted uniformly throughout the stand, but options allow for planted trees to vary in density in relation to residual overstory basal area (see Ferguson and Crookston 1991). 
Step 10: Identify Best Trees

Step 11:

Accumulate Stand Statistics

Step 12: Pass Tree
Records

Step 13: Print Regeneration Summary
Heights of planted trees are calculated using equations developed for heights of subsequent trees. Age of planted trees is the number of years from planting to the end of the Prognosis Model cycle plus the age of the tree when planted.

Best trees are chosen from those that are established on the plot using the rules described in the section on field procedures. Best trees are assigned a lower priority for removal in thinning operations simulated by the Prognosis Model (see Wykoff and others 1982, pp. 16-17). Excess trees have a higher priority for removal.

Planted trees are included in the selection of best trees. Planted trees could be taller than natural regeneration of the same species; however, delays in planting could result in the natural regeneration being taller than planted trees, so planted trees are not always chosen as best trees.

This is primarily a bookkeeping step for the purpose of later printing the regeneration summary. Predictions by plot are stored for averaging that produces stand statistics:

Tree records are created during this step. Tree records created by the regeneration model are added to the Prognosis Model tree list. This step uses both the probability of stocking and the results of stocked plot predictions to assign a "trees-per-acre" value to new tree records. The trees-per-acre value assigned to each tree record is

$$
\mathrm{TPA}=(\mathrm{PS} * \mathrm{TPSP} * 300) / N
$$

where

$$
\begin{aligned}
\text { TPA } & =\text { trees per acre } \\
\text { PS } & =\text { plot probability of stocking } \\
\text { TPSP } & =\text { trees per stocked plot } \\
300 & =\text { inverse of plot size used in sampling } \\
N & =\text { number of plots and replicates being processed. }
\end{aligned}
$$

Each best tree on the plot becomes a separate tree record, so TPSP is 1.0 for best trees. Excess trees are accumulated by species, then tree records are created so that TPSP is $\leq 5$ trees.

The value of PS for planted trees is not the probability of stocking; rather, it is the density of planting specified by the user. Usually one tree record for each species being planted is created for each plot. Multiple records are created when high densities are planted (a tree record represents $>10$ trees per acre).

A regeneration summary is printed each time the regeneration model is invoked. The first tally in a tally sequence includes a heading that shows the stand identification, site preparation by year performed, and number of plots by habitat type group.

Each tally shows the cumulative probability of stocking and three summaries of regeneration by species. The first summary is for all trees regenerating during the cycle. This summary is similar to a conventional stand exam. The second summary lists best trees regenerating during the cycle. Densities and average heights are listed by species for best trees. Focusing on best trees gives a more realistic picture of potential crop trees in the stand. For example, one could determine the number of Douglas-fir that could be favored in the stand through a thinning operation. 
The third summary shows all trees less than 3.0 inches d.b.h. that are in the Prognosis Model tree list. This provides a view of all regeneration currently in the stand. Trees may be from a stand inventory, from a previous tally of the regeneration model, and from the current tally of the regeneration model.

\section{MODEL BEHAVIOR}

In this section we use the regeneration model to show example projections. Examples include the default conditions that have been used to illustrate equations, a comparison of five habitat types, and an example of the effects of western spruce budworm.

Example Projection

Comparison of Habitat Types
This projection is the same stand used to illustrate equations-a hypothetical clearcut in the Idaho Panhandle National Forests, Abies grandis/Clintonia uniflora habitat type, north aspect, 30 percent slope, 3,500 feet elevation, no planting, and no site preparation.

The computer file needed to make this projection (called keyword records in the Prognosis Model system) is shown in figure 15. Refer to Wykoff and others (1982) and Ferguson and Crookston (1991) for coding instructions. The default cycle length for the Prognosis Model is 10 years, so regeneration will be predicted at 10 and 20 growing seasons since the disturbance in 1990 .

Output from the regeneration model is shown in figure 16. New tree records are added at the end of the Prognosis Model cycle. There have been 10 growing seasons between the "spring" of 1990 and the "fall" of 1999 . The new regeneration is added at the end of the cycle so these trees are part of the stand when silvicultural prescriptions are simulated at the beginning of the next cycle.

After 10 growing seasons, the probability of stocking is 0.7380 and regeneration density is 772 trees per acre. Of the 772 trees, 562 are best trees. Species composition of best trees is 57 percent grand fir, 22 percent Douglas-fir, 9 percent western white pine, 5 percent western larch, and less than 5 percent each of Engelmann spruce, lodgepole pine, and ponderosa pine.

After 20 growing seasons, the probability of stocking is 0.8631 and 309 more trees have become established, 209 of which are best trees. There are now 989 trees $<3$ inches d.b.h. in the Prognosis Model tree list. Some of these trees are from tally 2 and some are from tally 1.

Here we show how regeneration model projections vary with habitat type and elevation. Five projections were made, changing only habitat type and elevation between each projection. Other variables held constant were Idaho Panhandle National Forests, north aspect, 30 percent slope, no planting, no residual overstory basal area, no site preparation, and 10 years since harvest. The five projections were a Pseudotsuga menziesii/Physocarpos malvaceus habitat type at 3,000 feet elevation, an Abies grandis/Clintonia uniflora habitat type at 3,500 feet, a Tsuga heterophylla/Clintonia uniflora habitat type at 4,000 feet, an Abies lasiocarpa/Clintonia uniflora habitat type at 5,000 feet, and an Abies lasiocarpa/Xerophyllum tenax habitat type at 5,500 feet.

Results of these projections are shown in table 6. The Pseudotsuga menziesii/ Physocarpos malvaceus habitat type has the lowest probability of stocking $(0.2596)$ and density (195 trees per acre) of the five projections. The number of species present in the stand is limited because of the habitat type. The Abies grandis/Clintonia uniflora habitat type has a probability of stocking 
SCREEN

STDIDENT

ABGRCLUN

DESIGN

STDINFO

INVXEAR

NUMCYCLE

NOTREES

ESTAB

END

XAMPLE KEYWORDS FOR REGENERATION ESTABLISHMENT MODEI

PROCESS

STOP

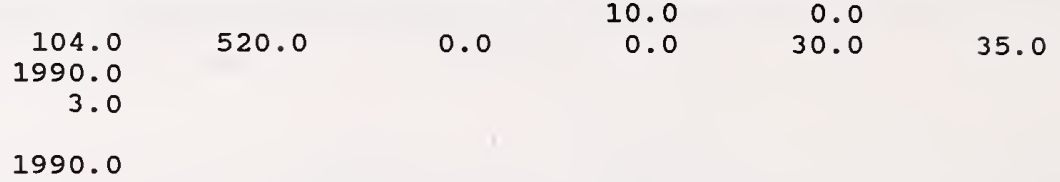

Figure 15-Example keyword records for projecting a stand in the Prognosis Model. Results of the regeneration model for this projection are shown in figure 16.

STAND GROWTH PROGNOSIS SYSTEM VERSION 6.10 -- INLAND EMPIRE

REGENERATION ESTABLISHMENT MODEL VERSION 2.0
STAND ID: ABGRCLUN
MANAGEMENT CODE: NONE

TALLY 1 AT 10 YEARS. PROBABILITY OF STOCKING IS 0.7380 IN THE FALL OF 1999.

\begin{tabular}{|c|c|c|}
\hline \multicolumn{3}{|c|}{$\begin{array}{l}\text { SUMMARY OF ALL } \\
\text { TREES REGENERATING } \\
\text { DURING THIS TALLY. }\end{array}$} \\
\hline PECIES & $\begin{array}{l}\text { TREES } \\
\text { /ACRE }\end{array}$ & $\begin{array}{l}\% \text { OF } \\
\text { TOTAI }\end{array}$ \\
\hline WP & 49. & \\
\hline L & 30. & \\
\hline DF & 193. & 25 \\
\hline GF & 461. & \\
\hline WH & 0 & \\
\hline C & 0 . & \\
\hline LP & 9. & \\
\hline $\mathrm{S}$ & 22 . & \\
\hline $\mathrm{AF}$ & 0 & \\
\hline $\mathrm{PP}$ & 9. & \\
\hline & 0 . & 0 \\
\hline
\end{tabular}

772 .

\begin{tabular}{|c|c|c|}
\hline \multicolumn{3}{|c|}{$\begin{array}{l}\text { SUMMARY OF BEST } \\
\text { TREES REGENERATING } \\
\text { DURING THIS TALLY. }\end{array}$} \\
\hline $\begin{array}{l}\text { TREES } \\
\text { /ACRE }\end{array}$ & $\begin{array}{l}\% \text { OF } \\
\text { TOTAL }\end{array}$ & $\begin{array}{l}\text { AVERAGE } \\
\text { HEIGHT }\end{array}$ \\
\hline $\begin{array}{r}49 . \\
30 . \\
124 . \\
319 . \\
0 . \\
0 . \\
9 . \\
22 . \\
0 . \\
9 . \\
0 .\end{array}$ & $\begin{array}{r}9 . \\
5 . \\
22 . \\
57 . \\
0 . \\
0 . \\
2 . \\
4 . \\
0 . \\
2 . \\
0 .\end{array}$ & $\begin{array}{l}4.5 \\
5.1 \\
4.7 \\
3.6 \\
0.0 \\
0.0 \\
2.3 \\
2.6 \\
0.0 \\
3.5 \\
0.0\end{array}$ \\
\hline & & \\
\hline
\end{tabular}

TREES $<3.0$ IN. DBH BEING PROJECTED BY THE PROGNOSIS MODEL TREES \% OF /ACRE TOTAL SPECIES

---D - - - - - - - -

$\begin{array}{rrr}49 . & 6 . & \mathrm{WP} \\ 30 . & 4 . & \mathrm{L} \\ 193 . & 25 . & \mathrm{DF} \\ 461 . & 60 . & \mathrm{GF} \\ 0 . & 0 . & \mathrm{WH} \\ 0 . & 0 . & \mathrm{C} \\ 9 . & 1 . & \mathrm{LP} \\ 22 . & 3 . & \mathrm{S} \\ 0 . & 0 . & \mathrm{AF} \\ 9 . & 1 . & \mathrm{PP} \\ 0 . & 0 . & -- \\ -7 .- & & \\ 772 . & & \end{array}$

TALLY 2 AT 20 YEARS. PROBABILITY OF STOCKING IS 0.8631 IN THE FALL OF 2009.

\begin{tabular}{|c|c|c|}
\hline $\begin{array}{l}\text { SUMMARY } \\
\text { TREES RI } \\
\text { DURING }\end{array}$ & $\begin{array}{l}\text { OF AL } \\
\text { EGENER } \\
\text { THIS T }\end{array}$ & $\begin{array}{l}\text { ATING } \\
\text { ALLY. }\end{array}$ \\
\hline SPECIES & $\begin{array}{l}\text { TREES } \\
\text { /ACRE }\end{array}$ & $\begin{array}{l}\% \text { OF } \\
\text { TOTAL }\end{array}$ \\
\hline & ---- & \\
\hline WP & 24. & 8 . \\
\hline L & 6. & 2. \\
\hline $\begin{array}{l}\text { DF } \\
\text { GF }\end{array}$ & $\begin{array}{r}56 . \\
206\end{array}$ & $\begin{array}{l}18 . \\
67 .\end{array}$ \\
\hline WH & 0. & 0. \\
\hline C & 0 . & 0 . \\
\hline LP & 0. & 0. \\
\hline $\mathrm{S}$ & 14. & 5. \\
\hline $\mathrm{AF}$ & 1. & 0. \\
\hline $\mathrm{PP}$ & 1 . & 0 . \\
\hline-- & 0. & 0. \\
\hline & 300 & \\
\hline
\end{tabular}

\begin{tabular}{|c|c|c|}
\hline $\begin{array}{l}\text { SUMMAI } \\
\text { TREES } \\
\text { DURIN }\end{array}$ & $\begin{array}{l}\text { RY OF } \\
\text { REGEN } \\
\text { G THIS }\end{array}$ & $\begin{array}{l}\text { BEST } \\
\text { ERATING } \\
\text { TALLY. }\end{array}$ \\
\hline $\begin{array}{l}\text { TREES } \\
\text { /ACRE }\end{array}$ & $\begin{array}{l}\% \text { OF } \\
\text { TOTAL }\end{array}$ & $\begin{array}{l}\text { AVERAGE } \\
\text { HEIGHT }\end{array}$ \\
\hline $\begin{array}{r}24 . \\
6 . \\
40 . \\
124 . \\
0 . \\
0 . \\
0 . \\
14 . \\
1 . \\
1 . \\
0 .\end{array}$ & $\begin{array}{r}11 . \\
3 . \\
19 . \\
59 . \\
0 . \\
0 . \\
0 . \\
7 . \\
0 . \\
0 . \\
0 .\end{array}$ & $\begin{array}{l}3.3 \\
4.2 \\
3.3 \\
2.2 \\
0.0 \\
0.0 \\
0.0 \\
2.0 \\
2.7 \\
4.7 \\
0.0\end{array}$ \\
\hline 209. & & \\
\hline
\end{tabular}

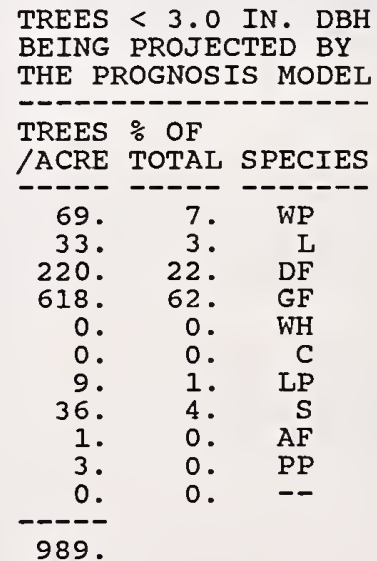

Figure 16-Regeneration model summary table. Keywords shown in figure 15 were used to make this projection. 
Table 6-Predicted probability of stocking and trees per acre by species for five projections where only habitat type and elevation were changed. Variables held constant were the Idaho Panhandle National Forests, north aspect, 30 percent slope, no planting, no residual overstory basal area, no site preparation, and 10 years since harvest

\begin{tabular}{lrrrrr}
\hline & \multicolumn{5}{c}{ Habitat type and elevation } \\
\cline { 2 - 6 } Stocking & $\begin{array}{c}\text { PSME/PHMA } \\
\mathbf{3 , 0 0 0} \mathbf{f t}\end{array}$ & $\begin{array}{c}\text { ABGR/CLUN } \\
\text { 3,500 ft }\end{array}$ & $\begin{array}{c}\text { TSHE/CLUN } \\
\mathbf{4 , 0 0 0} \mathbf{f t}\end{array}$ & $\begin{array}{c}\text { ABLA/CLUN } \\
\mathbf{5 , 0 0 0} \mathbf{f t}\end{array}$ & $\begin{array}{r}\text { ABLA/XETE } \\
\mathbf{5 , 5 0 0} \mathbf{f t}\end{array}$ \\
\hline Probability & & & & & \\
of stocking & 0.2596 & 0.7380 & 0.9015 & 0.6272 & 0.6671 \\
Trees/acre & 195 & 772 & 2,248 & 746 & 768 \\
Trees/acre & & & & & \\
by species & & & & & \\
WP2 & 0 & 49 & 129 & 16 & 22 \\
L & 18 & 30 & 5 & 18 & 82 \\
DF & 148 & 193 & 222 & 96 & 225 \\
GF & 0 & 460 & 801 & 236 & 61 \\
WH & 0 & 0 & 682 & 0 & 0 \\
C & 0 & 0 & 268 & 0 & 0 \\
LP & 10 & 9 & 16 & 3 & 71 \\
S & 0 & 22 & 5 & 50 & 79 \\
AF & 0 & 0 & 120 & 327 & 228 \\
PP & 19 & 9 & 0 & 0 & 0 \\
\hline
\end{tabular}

'See table 2, footnote 1 for habitat type abbreviations.

2See table 1 for species abbreviations.

Example of Spruce Budworm Effects

of 0.7380 and 772 trees per acre. Species composition is more diverse with grand fir having the highest density.

The Tsuga heterophylla/Clintonia uniflora habitat type has the highest probability of stocking (0.9015) and density (2,248 trees per acre) of the five habitat types projected. The Abies lasiocarpa/Clintonia uniflora habitat type regenerates well to subalpine fir ( 327 trees per acre). The probability of stocking on this habitat type is 0.6272 , and density is 746 trees per acre.

On the Abies lasiocarpa/Xerophyllum tenax habitat type, the probability of stocking and density are close to the Abies lasiocarpa/Clintonia uniflora habitat type. The probability of stocking is 0.6671 , and density is 768 trees per acre. The Abies lasiocarpa/Xerophyllum tenax habitat type has more western larch, Douglas-fir, and lodgepole pine. Grand fir is less frequent.

These five examples illustrate the diversity of results that can be expected among habitat types. Growth and mortality predictions in the Prognosis Model are also sensitive to habitat type, which helps represent the diversity of ecosystems found in the Northern Rocky Mountains of the Western United States.

The effects of western spruce budworm on regeneration success have not been dramatic in the separate equations shown thus far. However, the cumulative effects of budworm can be quite important, as will be illustrated by exercising the model with and without budworm.

Two hypothetical stands were chosen for illustration. The first is a clearcut in the Lolo National Forest in Montana at 4,500 feet elevation, north aspect, 30 percent slope, no planting, no site preparation, Pseudotsuga menziesiil Symphoricarpos albus habitat type, and 10 years since harvest. The second stand is the same except the elevation is 5,500 feet and the habitat type is 
Abies lasiocarpa/Carex geyeri. These two stands were projected with and without budworm defoliation for the time period 5 years before harvest through 10 years after harvest.

Results of these four projections are shown in table 7. Budworm decreases the probability of stocking from 0.4109 to 0.3485 for the Pseudotsuga menziesii/ Symphoricarpos albus habitat type and from 0.4391 to 0.3005 for the Abies lasiocarpa/Carex geyeri habitat type. Density also decreases in the defoliated stands. The Pseudotsuga menziesii/Symphoricarpos albus habitat type has 310 trees per acre without budworm compared to 250 with budworm. The Abies lasiocarpa/Carex geyeri habitat type has 450 trees per acre without budworm compared to 295 with budworm. The effect of budworm defoliation on stocking and density can be to reduce stocking below acceptable levels.

In addition, budworm defoliation changes species composition. The density of host species is reduced; for example, the density of Douglas-fir is 161 trees per acre without budworm compared to 123 with budworm in the Pseudotsuga menziesii/Symphoricarpos albus habitat type. In addition to changes in species composition, there can be a shift in the proportion of advance and subsequent regeneration within a species.

Seedling heights are also affected by budworm. Host species are shorter. This is caused by a longer delay to germination of an established seedling or

Table 7-Results of projecting two stands with and without budworm defoliation for the time period 5 years before harvest through 10 years after harvest. Results are shown as of 10 years

\begin{tabular}{|c|c|c|c|c|}
\hline \multirow[b]{3}{*}{ Stocking } & \multicolumn{4}{|c|}{ Habitat type and elevation } \\
\hline & \multicolumn{2}{|c|}{ PSME/SYAL, ${ }^{1} 4,500 \mathrm{ft}$} & \multicolumn{2}{|c|}{ ABLA/CAGE, $5,500 \mathrm{ft}$} \\
\hline & Budworm & No budworm & Budworm & No budworm \\
\hline $\begin{array}{l}\text { Probability } \\
\text { of stocking }\end{array}$ & 0.3485 & 0.4109 & 0.3005 & 0.4391 \\
\hline Trees/acre & 250 & 310 & 295 & 450 \\
\hline \multicolumn{5}{|l|}{$\begin{array}{c}\text { Trees/acre } \\
\text { by species }\end{array}$} \\
\hline$W P^{2}$ & 0 & 0 & 0 & 0 \\
\hline L & 62 & 75 & 0 & 0 \\
\hline DF & 123 & 161 & 39 & 63 \\
\hline GF & 0 & 0 & 11 & 25 \\
\hline WH & 0 & 0 & 0 & 0 \\
\hline C & 0 & 0 & 0 & 0 \\
\hline LP & 29 & 32 & 105 & 164 \\
\hline$s$ & 0 & 0 & 50 & 37 \\
\hline AF & 0 & 0 & 90 & 161 \\
\hline PP & 36 & 42 & 0 & 0 \\
\hline \multicolumn{5}{|c|}{$\begin{array}{l}\text { Average heights } \\
\text { of best trees ( } \mathrm{ft} \text { ) }\end{array}$} \\
\hline L & 4.2 & 4.4 & - & - \\
\hline DF & 4.9 & 4.2 & 4.0 & 3.9 \\
\hline GF & - & - & 2.8 & 3.0 \\
\hline LP & 3.7 & 3.4 & 3.1 & 3.0 \\
\hline S & - & - & 2.5 & 2.7 \\
\hline $\mathrm{AF}$ & - & - & 4.1 & 3.8 \\
\hline PP & 5.7 & 5.6 & - & - \\
\hline
\end{tabular}

${ }^{1}$ See table 2, footnote 1, for habitat type abbreviations.

${ }^{2}$ See table 1 for species abbreviations. 
by slower growth. Yet, notice that the average height of best trees for Douglasfir in the Pseudotsuga menziesii/Symphoricarpos albus habitat type is 4.9 feet for the budworm projection and 4.2 feet without budworm (table 7). This occurs because budworm changes the proportion of advance and subsequent regeneration within a species. Budworm reduces the probability of subsequent Douglas-fir (appendix B, table 13) but does not change the probability of advance Douglas-fir (appendix B, table 12). Thus, there is a greater proportion of taller advance Douglas-fir, increasing the average height for that species.

Nonhost species can be taller as well. This effect could be due to earlier establishment of nonhost species or better growth rates because of less competition.

In summary, there are four effects of western spruce budworm represented in the regeneration model. First is a reduction in the probability of stocking. Second is reduced number of trees per stocked plot. The significance of reductions in the probability of stocking (PS) and the number of trees per stocked plot (TPSP) becomes clear when densities are assigned using equation 4:

$$
\mathrm{TPA}=(\mathrm{PS} * \mathrm{TPSP} * 300) / N
$$

PS and TPSP interact multiplicatively, so small reductions in either (or both) can have large impacts.

The third effect of budworm is to change species composition of the new stand. Fewer host species regenerate in the new stand. The fourth effect is to change heights of regeneration. Nonhost species may become taller relative to host species that are under attack by budworm. Subsequent host species in defoliated stands may be shorter, primarily due to delays in becoming established. However, average heights of host species may be taller with budworm defoliation than without defoliation. This happens when the proportion of advance regeneration for a species increases relative to subsequent regeneration. The taller advance regeneration increases the average height for the species.

\section{OTHER MODEL FEATURES}

Most of the details about the regeneration model have been discussed. A few additional topics may be of interest to others developing a similar model.

Model calibration is a process of adjusting the probability of stocking curve to coincide with an inventory. This adjustment takes place whenever the year of inventory is within the years the regeneration model is making predictions. A stand more densely stocked than expected has less room for additional regeneration, while a stand less densely stocked than expected has more room for regeneration.

We considered using the ratio of stocked plots to calibrate the probability of stocking. However, this calibration method would not work for inventories with plot sizes other than $1 / 300$-acre.

This drawback was eliminated by developing an equation predicting the proportion of plots that are stocked from the number of trees per acre. The equation is

$$
\text { RATIO }=[1+\exp -(-5.17397+0.85131 * \ln (\mathrm{TPA}))]^{-1}
$$

where

RATIO $=$ proportion of plots that are stocked

TPA $=$ trees per acre in the stand $<3$ inches d.b.h. 
Consistency of Predictions
This equation has an $r$-square of 0.7694 and was developed from 362 stands in which 10 or more $1 / 300$-acre plots were sampled and on which all established regeneration was recorded. The relationship between stocking and density is shown in figure 17.

The predicted ratio of stocked plots is then used to mathematically adjust the probability of stocking equations given in appendix B, table 9. The adjustment is made to $\Sigma \beta_{i} X_{i}$ in the probability equation

$$
P=\left(1+e^{-\left(\Sigma \beta_{i} X_{i}\right)}\right)^{-1}
$$

so that the probability remains bounded in the interval $[0,1]$.

Figure 18 illustrates the calibration procedure. Line $\mathrm{A}$ is the probability of stocking curve generated from the Abies grandis series equation in appendix B, table 9 . Line B represents the same stand that was inventoried at 3 years since harvest and is more densely stocked than expected. Line $C$ represents the same stand as line $\mathrm{A}$, but it is less densely stocked than expected at 3 years. Calibration adjusts lines $B$ and $C$ to coincide with the inventories (points $\mathrm{b}$ and $\mathrm{c}$ ). Adjusted predictions (lines $\mathrm{B}$ and $\mathrm{C}$ ) are still bounded within the interval $[0,1]$.

A second part of calibration concerns creating new tree records. If the actual number of trees on the plot exceeds the predicted number, no new tree records are created for that plot.

The regeneration model uses pseudo-random numbers to make unbiased, discrete choices from a number of possibilities; for example, the species that will occupy a plot. This feature mimics stochastic variation seen in nature. Regeneration in a stand would vary depending on the year it was harvested because of differences in weather, seed crops, and animal/insect activity

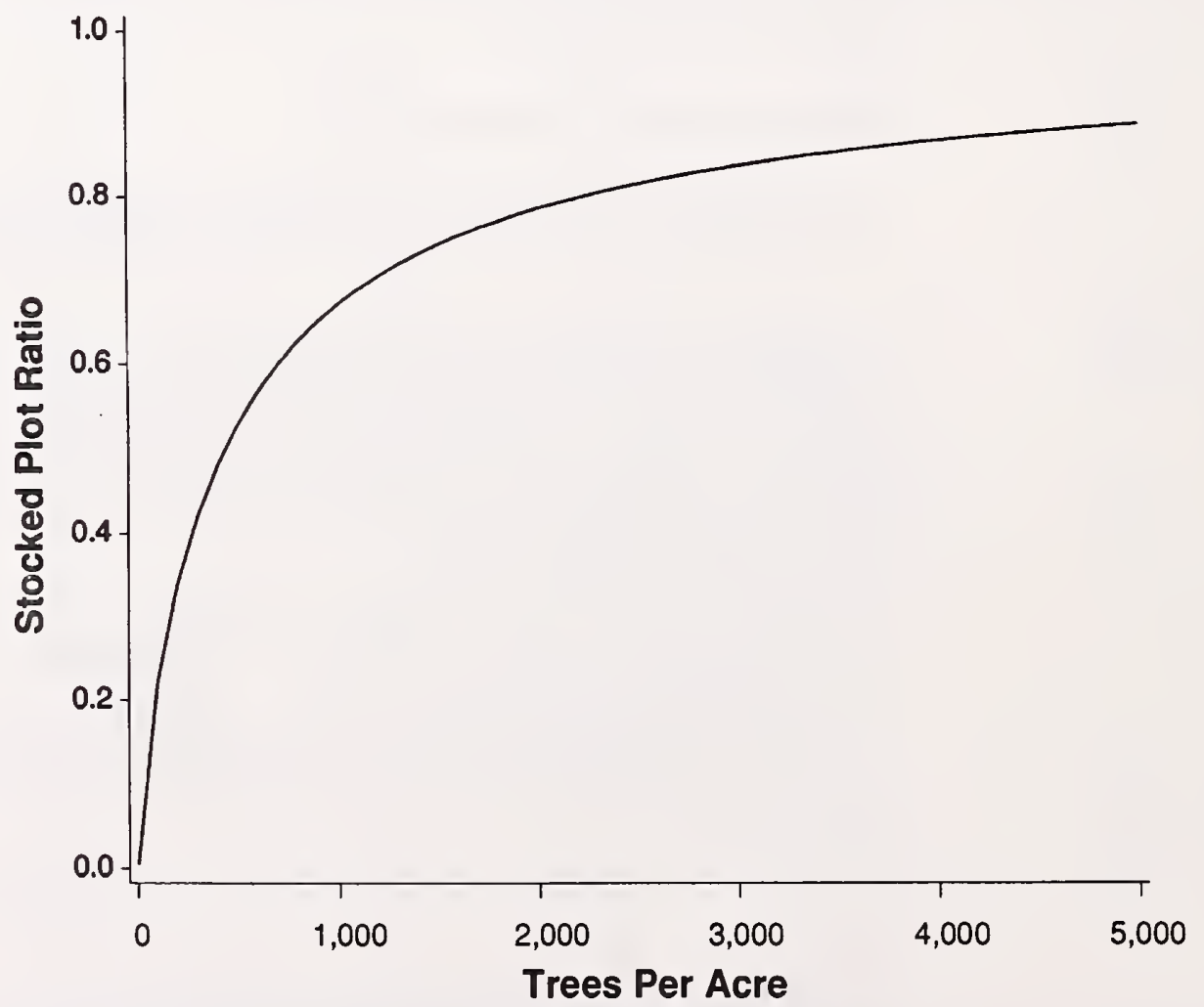

Figure 17-The relationship of trees per acre to stocked plot ratio. 


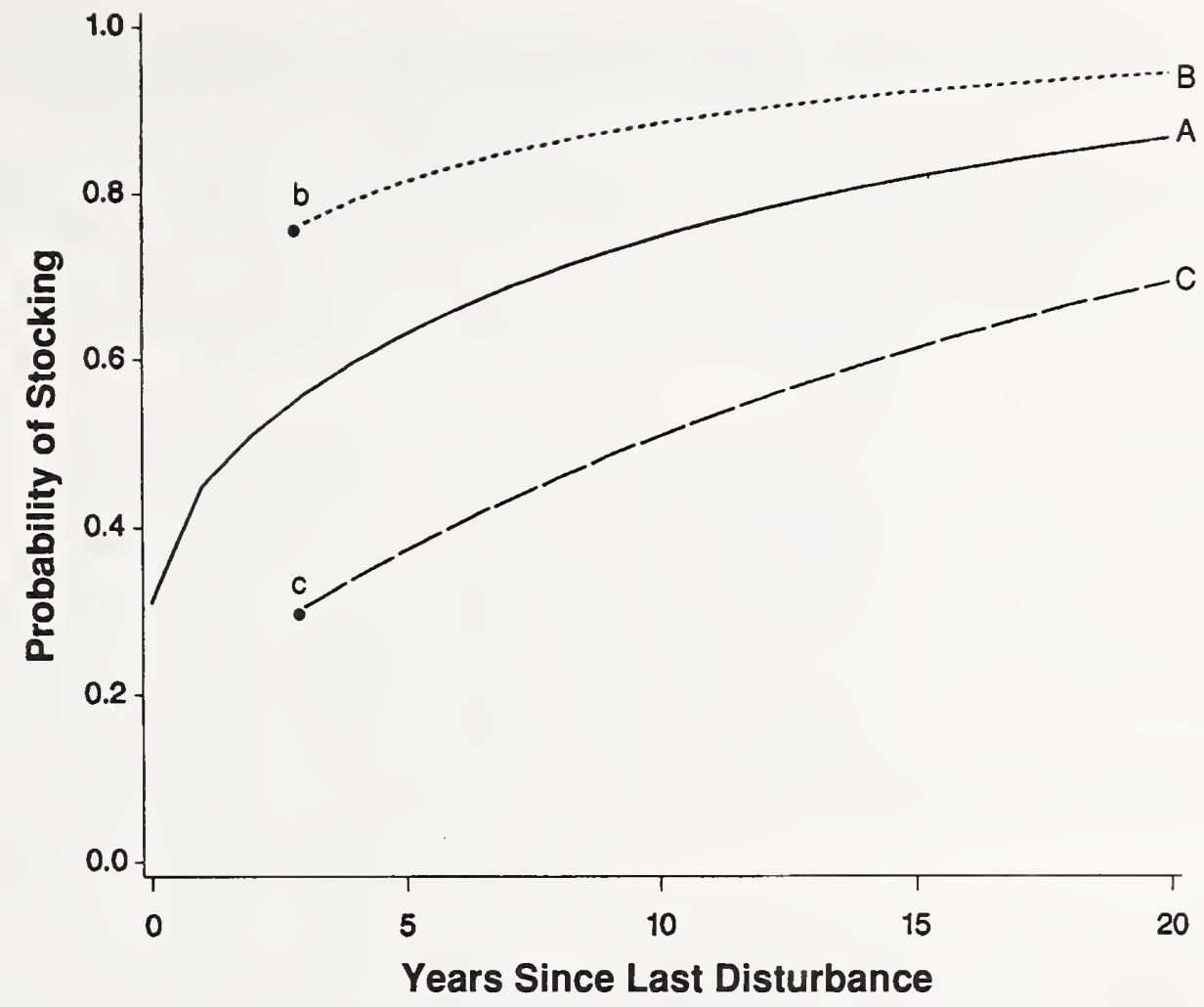

Figure 18-Use of the calibration feature in the Regeneration Establishment Model. Line A is the predicted probability of stocking curve. Point $b$ represents an inventory from the same stand but stocking is better than predicted. This information is used to adjust the probability stocking curve upward to line $\mathrm{B}$. Point $\mathrm{c}$ represents an inventory from the same stand as line $A$ but stocking is poorer than predicted. The probability of stocking curve is adjusted downward (line C).

from year to year. Variation can also be expected among inventories of the same stand. If different starting points are chosen for a transect or sampling grid, one would expect different results from the inventory.

The use of pseudo-random numbers in the regeneration model also resulted in inconsistencies among projections of the same stand where projections differed only in cycle lengths. For example, when two 5-year cycles are used instead of one 10-year cycle, the pseudo-random numbers are used in a different sequence between projections. Consistency was obtained by using pseudorandom numbers in the same order for all tallies within a tally sequence.

To further improve consistency, species composition is held constant at 10 years since last disturbance. This is necessary because of the relative increases and decreases over time in the probability of species presented in appendix B. Species composition is relatively stable at 10 years, and none of the species in the model has long delays to establishment.

An example of consistency among runs is given in table 8 . Three projections are compared-four 5-year projections, two 10-year projections, and one 20 -year projection. The probability of stocking, density, and species composition are nearly identical, regardless of cycle length. The small differences that do occur are attributable to very slight differences in probabilities when regeneration from one tally adds basal area to the stand in the next tallythe probability of stocking and species probabilities are shifted slightly. 
Table 8-Example projections to compare consistency of various cycle lengths using the same stand. Projection A is four 5-year cycles, projection B is two 10-year cycles, and projection $\mathrm{C}$ is one 20 -year cycle

\begin{tabular}{|c|c|c|c|c|c|c|c|}
\hline \multirow[b]{2}{*}{ Stocking } & \multicolumn{4}{|c|}{ Projection A } & \multicolumn{2}{|c|}{ Projection B } & \multirow{2}{*}{$\frac{\text { Projection C }}{20 \mathrm{yr}}$} \\
\hline & $5 \mathrm{yr}$ & $10 \mathrm{yr}$ & $15 \mathrm{yr}$ & $20 \mathrm{yr}$ & $10 \mathrm{yr}$ & $20 \mathrm{yr}$ & \\
\hline $\begin{array}{l}\text { Cumulative } \\
\text { probability } \\
\text { of stocking }\end{array}$ & 0.6186 & 0.7380 & 0.8126 & 0.8669 & 0.7380 & 0.8631 & 0.8601 \\
\hline $\begin{array}{c}\text { Cumulative } \\
\text { trees/acre }\end{array}$ & 582 & 772 & 943 & 1,086 & 772 & 1,081 & 1,076 \\
\hline $\begin{array}{c}\text { Cumulative } \\
\text { trees/acre } \\
\text { by species }\end{array}$ & & & & & & & \\
\hline WP' & 41 & 49 & 59 & 74 & 49 & 73 & 72 \\
\hline $\mathrm{L}$ & 21 & 30 & 34 & 37 & 30 & 36 & 41 \\
\hline DF & 157 & 192 & 222 & 248 & 193 & 249 & 262 \\
\hline GF & 330 & 462 & 575 & 667 & 460 & 667 & 635 \\
\hline WH & 0 & 0 & 0 & 0 & 0 & 0 & 0 \\
\hline C & 0 & 0 & 0 & 0 & 0 & 0 & 0 \\
\hline LP & 7 & 8 & 14 & 20 & 9 & 9 & 20 \\
\hline$S$ & 18 & 22 & 29 & 30 & 22 & 36 & 36 \\
\hline AF & 0 & 0 & 0 & 0 & 0 & 1 & 0 \\
\hline PP & 8 & 9 & 10 & 10 & 9 & 10 & 10 \\
\hline
\end{tabular}

'See table 1 for species abbreviations.

Ingrowth

\section{Automatic Tallies}

Ingrowth is regeneration that occurs after the 20 -year regeneration period. It is the continued succession by shade-tolerant species, and the regeneration of trees into gaps in the overstory canopy. An ingrowth tally of regeneration is predicted every 20 years if the regeneration model has not been invoked during that time, and no regeneration activities are scheduled for the next Prognosis Model cycle.

Data collected for the regeneration model did not specifically address ingrowth into undisturbed stands. However, the data contain many plots representing conditions where ingrowth occurs. These are areas with fairly dense overstory canopies where no harvesting or site preparation had taken place (see table 5). The systematic arrangement of transects or sampling grids in selection, sanitation, or salvage harvests resulted in many of these plots being included in the sample.

When predicting ingrowth, all plots are simulated as receiving no site preparation. Ingrowth tree records are created and passed to the Prognosis Model. An assortment of tree sizes is added to the stand because trees up to 20 years old can be established. The trees then survive and grow based on tree, site, and stand characteristics.

Simulation of ingrowth creates more realistic projections of stand development over time. It also allows projections that simulate succession over long time periods. The Prognosis Model with the regeneration model can be used in areas of forest management that require evaluation of uneven-age and old-growth silviculture.

The Prognosis Model includes a feature that invokes an automatic scheduling of the regeneration model when trees are removed. Thinnings scheduled by the user may have opened the stand enough for regeneration to become established. 


\section{Site Preparation}

\section{Regeneration Model Variants}

\section{Regeneration Sprouts}

These situations are detected and automatic tallies scheduled when certain threshold values are exceeded.

If 10 to 30 percent of either the trees per acre or the total cubic-foot volume is removed, a single regeneration tally is scheduled. A tally sequence is scheduled when more than 30 percent of either the trees per acre or the cubic-foot volume is removed. Nothing is scheduled if removals are less than 10 percent. The default values of 10 and 30 percent can be changed by the user.

Site preparation is a very important predictor of regeneration success, species composition, and growth rates. Most model users either specify the percentages of site preparation in the prescription, or they code plot-by-plot site preparations on stand examination records. For model users who do not specify site preparation(s), equations were developed to predict default probabilities. Plots used to develop these equations came from stands not deliberately prepared mechanically or by burning.

Default site preparation equations are given in appendix B, table 20. Only aspect, slope, residual basal area, elevation, and habitat type series are important independent variables.

The Prognosis Model was first developed for northern Idaho and adjacent portions of Montana and Washington (Stage 1973; Wykoff and others 1982). The Prognosis Model has also been calibrated for other geographic areas. Geographic versions are called variants.

Prognosis Model variants that do not have a calibrated regeneration model have an abbreviated version of the regeneration model. In these variants, creation of tree records representing natural regeneration is specified by the user in a manner similar to planting (Ferguson and Crookston 1991). Users describe expected regeneration in terms of species and density. Expected regeneration is estimated by the user using historical data or experience.

Some Prognosis Model variants represent species that sprout from roots or stumps of harvested trees. For these variants, subroutines that create tree records for sprouts were added to the regeneration model. Information about trees removed at the beginning of the cycle is stored for use at the end of the cycle when the number and size of sprouts is predicted. Each variant will be different because of the species and environment being represented, but once equations predicting the number and size of sprouts are developed, they can readily be inserted in the regeneration model.

\section{DISCUSSION}

Version 2 of the Regeneration Establishment Model became available with the release of version 6.1 of the Prognosis Model. Version 2 of the regeneration model covers five habitat type series in Montana and in central and northern Idaho. Abbreviated regeneration models are available with Prognosis Model variants covering other locations in the Western United States.

The regeneration model is based on a sample size of $12,128^{1 / 300}$-acre plots from 537 stands. Data represent all aspects, 0-110 percent slopes, 0-390 square feet of residual overstory basal area, 2,400-7,400 feet elevation, four site preparation methods, and 0-16 years of budworm defoliation. Stands were chosen using stratified random sampling procedures. Stratification 
assured replicated coverage of important variables-habitat type series, site preparation, overstory density, and level of spruce budworm defoliation. Stands were randomly selected to ensure an unbiased choice among all candidate stands. Plots within stands were made as independent as possible by recording plot-specific variables whenever feasible and by spacing plots throughout the stand.

We feel that unbiased stand selection procedures are crucial to developing a regeneration model because results are very dependent on probabilities. For example, the probability of stocking depends on the proportions of stocked and nonstocked plots. These proportions could be easily changed if study areas are not chosen in an unbiased manner.

The importance of random stand selection does not mean that case history studies of individual or small groups of stands are not needed. These studies provide very useful information on silvics of species, regeneration success, processes leading to successful regeneration, species composition, and so on. Case history studies helped us design this study, but it is inappropriate to use case history studies to develop a regeneration model because of potential problems with low number of stands in the sample, narrow range of years of treatment, and the possibility of unintended stand selection bias.

Stands used to develop the regeneration model were chosen from a list of stands harvested by commonly used methods in the Northern Rocky Mountains. These stands were harvested as part of commercial timber removals on Ranger Districts and State and corporate ownerships. Thus, the regeneration model should reflect what can be expected when actual silvicultural prescriptions are implemented.

Retrospective examination procedures may not be suitable for developing regeneration models in all cases. Sometimes stand conditions prior to harvest may be important in determining regeneration in the next rotation. For example, the presence of serotinous lodgepole pine cones is important for lodgepole pine regeneration.

Retrospective examination procedures used in this study have the drawback of sampling stands that are up to 20 years old. During that time, technology could improve regeneration success. The same concern is true of a prospective study. Retrospective examinations can be conducted in a much shorter time frame-say 2 to 3 years to collect a sufficient amount of data. Retrospective studies, however, can only be done if adequate historical records have been kept for each stand.

Another important part of data collection is to sample from a range of treatment years. This spreads out the sporadic effects of variables not explicitly accounted for in the model-weather, seed crops, animals, insects, disease, and so on. Data collected over a range of treatment years should result in model predictions that are closer to long-term averages.

An ecologically based land classification system was very important for model development. The regeneration model makes extensive use of habitat types and habitat type groups. Other alternatives would not have worked as well. For example, site index does not provide the necessary information to model regeneration success. Site index alone is not useful for determining the species that can occupy the site.

Ecological land classifications provide a logical framework within which to model regeneration success. The successional pathways to a climax forest can be modeled using an ecological classification system. Management implications can be cataloged using the same system. The analyses and model 
presented in this paper are ecologically based and should give reliable estimates of future stocking under various management strategies.

Although we classified stands by regeneration method-clearcut, seedtree, shelterwood, and selection-many stands did not fit the classical definition, and there was usually substantial variation within stands. Thus, regeneration method was not used as an independent variable. Sampling for the regeneration model was done plot by plot because of the heterogeneous nature of stands. Because the regeneration model predicts regeneration on a plotby-plot basis, it is flexible for changes in forest management practices. The regeneration model should be applicable to a wide variety of silvicultural prescriptions, from stands that are treated homogeneously to stands that are treated to create heterogeneous stand conditions.

It may be necessary and desirable to update the regeneration model in the future. Updates would incorporate changes in regeneration technology, account for long-term changes in climate, and represent shifts in species composition (such as increasing proportion of western white pine resistant to white pine blister rust [Cronartium ribicola]). The ability to update the regeneration model will depend on historical records being kept today.

\section{REFERENCES}

Bailey, R. L.; Dell, T. R. 1973. Quantifying diameter distributions with the Weibull function. Forest Science. 19: 97-104.

Burns, R. M.; Honkala, B. H. 1990. Silvics of North America. Vol. 1. Conifers. Agric. Handb. 654. Washington, DC: U.S. Department of Agriculture, Forest Service. 675 p.

Carlson, C. E.; Ferguson, D. E. [In preparation]. Conifer regeneration and early stand development after timber harvest in the Northern Rocky Mountains. Missoula, MT: U.S. Department of Agriculture, Forest Service, Intermountain Research Station, Forestry Sciences Laboratory.

Carlson, C. E. 1988. Relations among stand structure, dispersal of secondinstar western spruce budworm, defoliation, and height growth of young conifers. Canadian Journal of Forest Research. 18: 794-800.

Carlson, C. E.; McCaughey, W. W. 1982. Indexing western spruce budworm activity through radial increment analysis. Res. Pap. INT-291. Ogden, UT: U.S. Department of Agriculture, Forest Service, Intermountain Research Station. 10 p.

Cooper, S. V.; Neiman, K. E.; Roberts, D. W. Rev. 1991. Forest habitat types of northern Idaho: a second approximation. Gen. Tech. Rep. INT-236. Ogden, UT: U.S. Department of Agriculture, Forest Service, Intermountain Research Station. $143 \mathrm{p}$.

Daubenmire, R. 1952. Forest vegetation of northern Idaho and adjacent Washington, and its bearing on concepts of vegetation classification. Ecological Monographs. 22: 301-330.

Daubenmire, R.; Daubenmire, J. B. 1968. Forest vegetation of eastern Washington and northern Idaho. Tech. Bull. 60. Pullman, WA: Washington Agricultural Experiment Station. 104 p.

Ferguson, D. E.; Stage, A. R.; Boyd, R. J. 1986. Predicting regeneration in the grand fir-cedar-hemlock ecosystem of the northern Rocky Mountains. For. Sci. Monogr. 26. Washington, DC: Society of American Foresters. 41 p.

Ferguson, D. E.; Crookston, N. L. 1991. User's guide to version 2 of the Regeneration Establishment Model: part of the Prognosis Model. Gen. Tech. 
Rep. INT-279. Ogden, UT: U.S. Department of Agriculture, Forest Service, Intermountain Research Station. $34 \mathrm{p}$.

Haig, I. T.; Davis, K. P.; Weidman, R. H. 1941. Natural regeneration in the western white pine type. Tech. Bull. 767. Washington, DC: U.S. Department of Agriculture. 99 p.

Hamilton, D. A., Jr. 1974. Event probabilities estimated by regression. Res. Pap. INT-152. Ogden, UT: U.S. Department of Agriculture, Forest Service, Intermountain Forest and Range Experiment Station. $18 \mathrm{p}$.

Hamilton, D. A., Jr.; Brickell, J. E. 1983. Modeling methods for a two-state system with continuous responses. Canadian Journal of Forest Research. 13: $1117-1121$.

Kirk, R. E. 1982. Experimental design: procedures for the behavioral sciences. 2d ed. Belmont, CA: Brooks/Cole Publishing Co. 911 p.

Moeur, M. 1985. COVER: a user's guide to the CANOPY and SHRUBS extension of the Stand Prognosis Model. Gen. Tech. Rep. INT-190. Ogden, UT: U.S. Department of Agriculture, Forest Service, Intermountain Research Station. 49 p.

Pfister, R. D.; Kovalchik, B. L.; Arno. S. F.; Presby, R. C. 1977. Forest habitat types of Montana. Gen. Tech. Rep. INT-34. Ogden, UT: U.S. Department of Agriculture, Forest Service, Intermountain Forest and Range Experiment Station. 174 p.

Stage, A. R. 1973. Prognosis model for stand development. Res. Pap. INT-137. Ogden, UT: U.S. Department of Agriculture, Forest Service, Intermountain Forest and Range Experiment Station. 32 p.

Stage, A. R. 1976. An expression for the effect of aspect, slope, and habitat type on tree growth. Forest Science. 22: 457-460.

Steele, R.; Pfister, R. D.; Ryker, R. A.; Kittams, J. A. 1981. Forest habitat types of central Idaho. Gen. Tech. Rep. INT-114. Ogden, UT: U.S. Department of Agriculture, Forest Service, Intermountain Forest and Range Experiment Station. 138 p.

Wykoff, W. R.; Crookston, N. L.; Stage, A. R. 1982. User's guide to the Stand Prognosis Model. Gen. Tech. Rep. INT-133. Ogden, UT: U.S. Department of Agriculture, Forest Service, Intermountain Forest and Range Experiment Station. 112 p.

Wykoff, W. R. 1986. Supplement to the user's guide for the Stand Prognosis Model-version 5.0. Gen. Tech. Rep. INT-208. Ogden, UT: U.S. Department of Agriculture, Forest Service, Intermountain Research Station. 36 p. 


\section{APPENDIX A: HABITAT TYPE GROUPINGS}

This appendix documents results of analyses to combine similar habitat types into groups for the purpose of predicting regeneration establishment. An analysis of variance was performed by habitat type series (Pseudotsuga menziesii, Abies grandis, Thuja plicata, Tsuga heterophylla, and Abies lasiocarpa) using Scheffe's $S$ test to group similar habitat types, using a 0.05 significance level. Scheffe's test can be used with an unequal number of observations per habitat type, and it is robust regarding nonnormality and heterogeneity of variance (Kirk 1982).

The results of these analyses, by themselves, did not determine the final groupings. There is variation within habitat type in years since disturbance, aspect, elevation, geographic location, and so on that is not accounted for in the analyses. The results were useful in developing preliminary groupings that were reviewed by forest ecologists. Their suggestions were incorporated to arrive at the final groupings.

In the following tables, TPSP means number of trees per stocked plot and SPSP means number of species per stocked plot. See table 2, footnote 1, for definitions of species abbreviations used in naming habitat types. The stocking mean is the ratio of plots that were stocked. Habitat types underlined with the same line were not significantly different at the 0.05 level. Habitat types with fewer than 25 plots sampled were omitted from the analyses, but were later placed in the group thought to be most similar.

\section{Pseudotsuga menziesii Series}

Stocking mean $=\quad \begin{array}{llllllllll}0.73 & 0.72 & 0.51 & 0.42 & 0.33 & 0.33 & 0.30 & 0.28 & 0.25 & 0.25\end{array}$

PSME/ VACA LIBO VAGL AGSP SYOR SPBE CARU CAGE PHMA SYAL

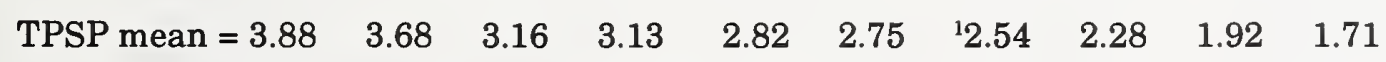

PSME/ LIBO VACA VAGL CARU CAGE SYAL AGSP PHMA SYOR SPBE

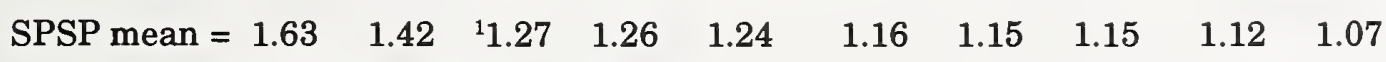

PSME/ VACA LIBO AGSP VAGL CARU SYOR SYAL PHMA CAGE SPBE

Final groupings: $1=$ PSME/VAGL, LIBO, VACA

2 = PSME/CARU, CAGE, AGSP, FEID

3 = PSME/PHMA, ACGL

4 = PSME/SYAL, SPBE, SYOR, ARUV, Misc.

'Average of only 11 stocked plots.

\section{Abies grandis Series}

Stocking mean $=\begin{array}{lllllllll}0.85 & 0.77 & 0.51 & 0.50 & 0.42 & 0.39 & 0.38 & 0.38 & 0.33\end{array}$

ABGR/ CLUN LIBO CLUN ${ }^{1}$ XETE ASCA PHMA VAGL SPBE ACGL -XETE

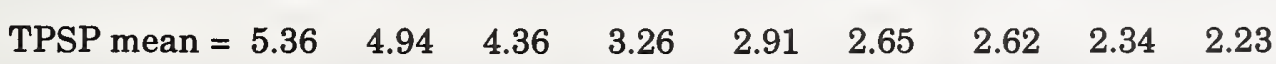

ABGR/ CLUN LIBO CLUN ${ }^{1}$ XETE PHMA VAGL SPBE ASCA ACGL -XETE

SPSP mean $=\begin{array}{lllllllll}1.92 & 1.77 & 1.50 & 1.48 & 1.48 & 1.33 & 1.30 & 1.28 & 1.20\end{array}$

ABGR/ CLUN LIBO XETE VAGL CLUN ${ }^{1}$ PHMA ACGL SPBE ASCA -XETE 
Final groupings: $5=\mathrm{ABGR} / \mathrm{LIBO}, \mathrm{CLUN}-\mathrm{XETE}$

$6=\mathrm{ABGR} / \mathrm{XETE}, \mathrm{VAGL}, \mathrm{COOC}, \mathrm{VACA}$

$7=$ ABGR/CLUN (except CLUN-XETE)

$8=$ ABGR/SPBE, ACGL, PHMA, ASCA, SETR

${ }^{1}$ Except CLUN-XETE.

\section{Thuja plicata Series}

Stocking mean $=0.61 \quad 0.56$

THPL/ CLUN ASCA

TPSP mean $=9.64 \quad 5.41$

THPL/ CLUN ASCA

SPSP mean $=1.75 \quad 1.48$

THPL/ CLUN ASCA

Final groupings: $9=$ THPL $/$ All

\section{Tsuga heterophylla Series}

Stocking mean $=0.72 \quad 0.59$

TSHE/ CLUN ASCA

TPSP mean $=10.66 \quad 5.30$

TSHE/ CLUN ASCA

SPSP mean $=2.05 \quad 1.85$

TSHE/ CLUN ASCA

Final groupings: $10=$ TSHE $/$ All

\section{Abies lasiocarpa Series}

Stocking mean $=$

$\begin{array}{lllllllllllllll}0.74 & 0.68 & 0.68 & 0.66 & 0.66 & 0.65 & 0.61 & 0.56 & 0.54 & 0.47 & 0.43 & 0.43 & 0.34 & 0.30 & 0.25\end{array}$

TSME ABLA ABLA ABLA ABLA ABLA ABLA ABLA ABLA ABLA TSME ABLA ABLA ABLA ABLA XETE VACA ALSI MEFE LIBO VASC VAGL XETE CLUN STAM CLUN CAGE CARU CACA ACGL

TPSP mean $=$

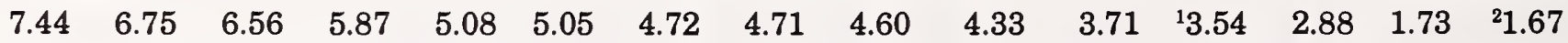

TSME ABLA ABLA ABLA ABLA ABLA ABLA ABLA ABLA ABLA ABLA TSME ABLA ABLA ABLA XETE MEFE CLUN VACA STAM LIBO VASC ALSI CARU VAGL XETE CLUN CACA CAGE ACGL

SPSP mean $=$

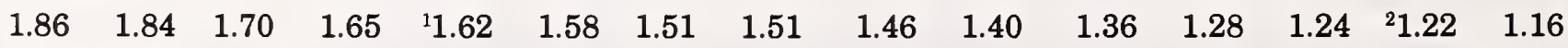

ABLA TSME ABLA ABLA TSME ABLA ABLA ABLA ABLA ABLA ABLA ABLA ABLA ABLA ABLA ALSI XETE LIBO CLUN CLUN MEFE VAGL XETE STAM VACA VASC CACA CARU ACGL CAGE 
Final groupings: $11=$ ABLA/VAGL, VASC, VACA

12 = ABLA/XETE, LIBO

13 = ABLA/CLUN, GATR

14 = ABLA/CAGE, CARU, ACGL, SPBE

$15=\mathrm{ABLA} / \mathrm{MEFE}, \mathrm{ALSI}$, and

TSME/CLUN, XETE, MEFE, STAM

16 = ABLA/CACA, STAM, LUHI

'Average of only 13 stocked plots.

${ }^{2}$ Average of only 9 stocked plots.

Percentage of Stocked Plots, Average Trees Per Stocked Plot, and Average Number of Species Per Stocked Plot by Habitat Type Group

\begin{tabular}{|c|c|c|c|c|}
\hline Group & Habitat types & $\begin{array}{l}\text { Ratio of } \\
\text { stocked } \\
\text { plots }\end{array}$ & $\begin{array}{c}\text { Trees per } \\
\text { stocked } \\
\text { plot }\end{array}$ & $\begin{array}{l}\text { Species per } \\
\text { stocked } \\
\text { plot }\end{array}$ \\
\hline 1 & PSME/VAGL, LIBO, VACA & 0.59 & 3.49 & 1.36 \\
\hline 2 & PSME/CARU, CAGE, AGSP, FEID & .29 & 2.99 & 1.21 \\
\hline 3 & PSME/PHMA, ACGL & .25 & 2.31 & 1.14 \\
\hline 4 & PSME/SYAL, SPBE, SYOR, ARUV, Misc. & .28 & 2.35 & 1.13 \\
\hline 5 & ABGR/LIBO, CLUN-XETE & .79 & 5.06 & 1.81 \\
\hline 6 & ABGR/XETE, VAGL, COOC, VACA & .46 & 3.22 & 1.49 \\
\hline 7 & ABGR/CLUN (except CLUN-XETE) & .51 & 4.36 & 1.48 \\
\hline 8 & ABGR/SPBE, ACGL, PHMA, ASCA, SETR & .37 & 2.53 & 1.28 \\
\hline 9 & THPL/All & .61 & 9.53 & 1.74 \\
\hline 10 & TSHE/All & .72 & 10.53 & 2.05 \\
\hline 11 & ABLA/VAGL, VASC, VACA & .63 & 4.73 & 1.44 \\
\hline 12 & ABLA/XETE, LIBO & .58 & 4.04 & 1.56 \\
\hline 13 & ABLA/CLUN, GATR & .54 & 6.53 & 1.65 \\
\hline 14 & ABLA/CAGE, CARU, ACGL, SPBE & .37 & 2.79 & 1.23 \\
\hline 15 & $\begin{array}{l}\text { ABLA/MEFE, ALSI } \\
\text { TSME/CLUN, XETE, MEFE, STAM }\end{array}$ & .66 & 6.78 & 1.66 \\
\hline 16 & ABLA/CACA, STAM, LUHI & .36 & 3.81 & 1.36 \\
\hline
\end{tabular}




\section{APPENDIX B: COEFFICIENTS FOR EQUATIONS}

Terms and abbreviations appearing in these tables may need some explanation. Variables are defined in table 3. Habitat type abbreviations are defined in table 2, footnote 1. Optimum aspect is calculated using the procedure developed by Stage (1976). The poorest aspects are 180 degrees from the optimum. Amplitude for probability of stocking equations uses SLO =0.3, TIME = 10 years, and the probability of stocking centered on 0.5. Amplitude was not calculated when the optimum aspect was not significant. NS stands for not significant at the 0.05 probability level. In this appendix footnotes appear in front of the items they refer to. That position should help avoid confusion with the superscripts for "squared" in $\mathrm{BAA}^{2}$, TPSP", and ELEV". 
Table 9-Probability of stocking equations for version 2 of the Regeneration Establishment Model. The form of the equation is $P=\left(1+e^{-\left(\Sigma B_{i} x_{i}\right)}\right)^{-1}$

\begin{tabular}{|c|c|c|c|c|c|}
\hline $\begin{array}{c}\text { Variable } \\
(X)\end{array}$ & $\begin{array}{c}\text { Pseudotsuga } \\
\text { menziesii } \\
\text { series } \\
(\beta) \\
\end{array}$ & $\begin{array}{c}\text { Abies } \\
\text { grandis } \\
\text { series } \\
(\beta) \\
\end{array}$ & $\begin{array}{c}\text { Thuja } \\
\text { plicatal } \\
\text { Tsuga } \\
\text { heterophylla } \\
\text { series } \\
(\beta) \\
\end{array}$ & $\begin{array}{c}\text { Abies } \\
\text { Iasiocarpa } \\
\text { series } \\
(\beta)\end{array}$ & $\begin{array}{c}\text { All } \\
\text { roads } \\
(\beta)\end{array}$ \\
\hline 1 Intercept & -0.82988 & -2.42977 & -6.21669 & -0.43035 & -2.10728 \\
\hline $2 \operatorname{COS}(A S P)^{*} S L O^{1 / 2 *} T_{I M E}^{1 / 2}$ & .07406 & .39253 & .58797 & .24625 & 0 \\
\hline 3 SIN(ASP) ${ }^{*} \mathrm{SLO}^{1 / 2 *} \mathrm{TIME}^{1 / 2}$ & -.06721 & .11738 & .00742 & -.01938 & 0 \\
\hline 4 SLO $^{1 / 2 *}$ TIME $^{1 / 2}$ & -.02119 & -.31847 & .15254 & -.09997 & 0 \\
\hline 5 TIME $^{1 / 2}$ & 0 & .55349 & 0 & 0 & 0 \\
\hline 6 SQREGT & .21368 & 0 & .51481 & .23914 & .42067 \\
\hline 7 SQBWAF & .12913 & 0 & .44986 & .22470 & .18714 \\
\hline 8 BWB4 & 0 & 0 & 0 & -.11159 & -.35584 \\
\hline 9 ELEV & -.02706 & .07568 & .28859 & 0 & 0 \\
\hline 10 ELEV $^{2}$ & 0 & -.00083 & -.00395 & 0 & 0 \\
\hline $11 \mathrm{BAA}$ & 0 & .01382 & .00795 & 0 & .01113 \\
\hline $12 \mathrm{BAA}^{2}$ & 0 & -.00008 & -.00004 & 0 & 0 \\
\hline $13 \ln (B A A)$ & 0 & 0 & 0 & .13678 & 0 \\
\hline $14 \cos (A S P) * S L O * B A A$ & 0 & -.01346 & -.01790 & 0 & 0 \\
\hline 15 SIN(ASP) ${ }^{*}$ SLO*BAA & 0 & -.01348 & -.00600 & 0 & 0 \\
\hline 16 'NONE & 0 & 0 & 0 & 0 & No data \\
\hline $17 \mathrm{MECH}$ & -.18027 & -.17355 & -.18546 & .06815 & No data \\
\hline 18 BURN & -.48567 & -.17355 & -.34635 & -.34280 & No data \\
\hline 19 PLANT & .74846 & 0 & 0 & 0 & 0 \\
\hline \multicolumn{6}{|l|}{ Habitat type groups } \\
\hline 20 PSMENAGL & 1.14975 & No data & No data & No data & 0 \\
\hline 21 PSME/CARU & .07020 & No data & No data & No data & 0 \\
\hline 22 PSME/PHMA & -.11583 & No data & No data & No data & 0 \\
\hline 23 PSME/SYAL & 0 & No data & No data & No data & 0 \\
\hline 24 ABGR/LIBO & No data & .54137 & No data & No data & .59764 \\
\hline 25 ABGR/XETE & No data & -.05775 & No data & No data & .59764 \\
\hline 26 ABGR/CLUN & No data & 0 & No data & No data & .59764 \\
\hline 27 ABGR/SPBE & No data & -.17732 & No data & No data & .59764 \\
\hline 28 THPL/All & No data & No data & 0 & No data & 1.35479 \\
\hline 29 TSHE/All & No data & No data & .35600 & No data & 1.50736 \\
\hline 30 ABLANAGL & No data & No data & No data & .27860 & 1.16959 \\
\hline 31 ABLAXXETE & No data & No data & No data & .18176 & 1.16959 \\
\hline 32 ABLAVCLUN & No data & No data & No data & 0 & 1.16959 \\
\hline 33 ABLAVCAGE & No data & No data & No data & -.76407 & 1.16959 \\
\hline 34 ABLAMEFE & No data & No data & No data & .40383 & 1.16959 \\
\hline 35 ABLAVCACA & No data & No data & No data & -.83775 & 1.16959 \\
\hline \multicolumn{6}{|l|}{ National Forests } \\
\hline 36 Bitterroot & 1.07708 & 0 & No data & 0 & 0 \\
\hline 37 Panhandle & 0 & 0 & 0 & 0 & 0 \\
\hline 38 Clearwater & 0 & -.47893 & 0 & 0 & 0 \\
\hline 39 Colville & 0 & 0 & 0 & 0 & 0 \\
\hline 40 Deerlodge & .73060 & No data & No data & 0 & 0 \\
\hline 41 Flathead & .73060 & 0 & No data & 0 & 0 \\
\hline 42 Gallatin & .73060 & No data & No data & 0 & 0 \\
\hline 43 Helena & .73060 & No data & No data & 0 & 0 \\
\hline 44 Kootenai & No data & 0 & 0 & 0 & 0 \\
\hline 45 Lolo & 1.07708 & 0 & 0 & 0 & 0 \\
\hline 46 Nez Perce & 0 & -.41795 & 0 & 0 & 0 \\
\hline 47 Payette & .28613 & -1.08325 & No data & 0 & 0 \\
\hline 48 Boise & .80554 & -1.08325 & No data & 0 & 0 \\
\hline Chi-square & 22.05 & 33.38 & 7.60 & 26.88 & 27.16 \\
\hline Error mean square & 0.9923 & 1.0100 & 0.9973 & 1.0038 & 1.0307 \\
\hline Percent stocking & 30.90 & 49.54 & 65.37 & 55.97 & 51.24 \\
\hline Total No. of plots & 2,369 & 3,373 & 3,289 & 2,414 & 683 \\
\hline Optimum aspect & $318^{\circ}$ & $17^{\circ}$ & $1^{\circ}$ & $356^{\circ}$ & NS \\
\hline Amplitude & 0.09 & 0.34 & 0.47 & 0.21 & - \\
\hline
\end{tabular}

'Represented as part of the constant term to avoid a singular matnix. 
Table 10-Weibull distribution functions for determining the number of trees per stocked plot

$$
\operatorname{TPSP}=B[-\ln (1-X)]^{1 / C}+1
$$

where

$$
\begin{aligned}
& \text { TPSP }=\text { number of trees per stocked plot } \\
& X=a \text { uniform pseudo-random number in the interval }[0,1] \\
& B=\operatorname{EXP}\left[1.79862+0.64299^{*} \mathrm{COS}(\mathrm{ASP})^{*} \mathrm{SLO}\right. \\
& -0.34931^{\star} \mathrm{SIN}(\mathrm{ASP})^{*} \mathrm{~S} L O-2.18751^{*} \mathrm{SLO}-0.03815^{\star} \mathrm{ELEV} \\
& +0.27987^{*} \text { SQREGT }+0.15874^{*} \text { SQBWAF } \\
& +0.07241 \text { if Abies grandis series } \\
& +0.85008 \text { if Thuja/Tsuga series } \\
& +0.64994 \text { if Abies lasiocarpa series] } \\
& C=\operatorname{EXP}\left[-0.33367-0.00751^{\star} \mathrm{ELEV}+0.07164^{\star} \mathrm{SQREGT}\right. \\
& +0.06127^{*} \text { SQBWAF }
\end{aligned}
$$

\begin{tabular}{|c|c|c|c|c|c|c|}
\hline $\begin{array}{cc}\text { Variable } \\
i \quad(x)\end{array}$ & $\begin{array}{l}1 \text { species } \\
(\beta)\end{array}$ & $\begin{array}{c}2 \text { species } \\
(\beta)\end{array}$ & $\begin{array}{c}3 \text { species } \\
(\beta)\end{array}$ & $\begin{array}{c}4 \text { species } \\
(\beta)\end{array}$ & $\begin{array}{c}5 \text { species } \\
(\beta)\end{array}$ & $\begin{array}{c}6 \text { species } \\
(\beta)\end{array}$ \\
\hline 1 Constant & 1.39959 & -0.44188 & -2.05274 & -6.24551 & -2.04323 & -5.93804 \\
\hline $2 \cos (A S P) * S L O$ & 0 & .57776 & .07506 & -1.27740 & 0 & 0 \\
\hline 3 SIN(ASP)*SLO & 0 & .29407 & -.47116 & -.32990 & 0 & 0 \\
\hline 4 SLO & 0 & -.12877 & -.84038 & .42524 & 0 & 0 \\
\hline 5 REGT & -.02217 & .01657 & .00475 & .00137 & 0 & 0 \\
\hline 6 BWAF & -.03940 & -.00025 & .07635 & .07188 & 0 & 0 \\
\hline 7 ELEV & .02139 & -.01104 & -.01859 & 0 & -.05291 & 0 \\
\hline $8 \mathrm{BAA}$ & .00216 & 0 & 0 & 0 & 0 & 0 \\
\hline 9 PLANT & -.39803 & 0 & .28128 & .61675 & 0 & 0 \\
\hline 10 TPSP & 0 & -.01013 & .05466 & .05678 & .02188 & .02007 \\
\hline $11 \mathrm{TPSP}^{2}$ & 0 & 0 & -.00047 & -.00024 & 0 & 0 \\
\hline $12 \ln (T P S P)$ & -1.01790 & 0 & 0 & 0 & 0 & 0 \\
\hline \multicolumn{7}{|l|}{ Overstory climax } \\
\hline 13 'PSME & 0 & 0 & 0 & 0 & 0 & 0 \\
\hline 14 ABGR & -.69564 & .43695 & .67734 & 2.30190 & 0 & 0 \\
\hline 15 THPL & -.77642 & .42663 & .90042 & 2.60261 & 0 & 0 \\
\hline 16 TSHE & -1.22760 & .36357 & 1.29021 & 3.08950 & 0 & 0 \\
\hline 17 ABLA & -1.05898 & .72147 & .90065 & 2.15632 & 0 & 0 \\
\hline Chi-square & 14.94 & 7.01 & 20.35 & 13.82 & 13.29 & 1.00 \\
\hline Error mean square & 0.9900 & 1.0028 & 0.9975 & 0.9223 & 0.9402 & 0.8091 \\
\hline Percent occurrence & 40.34 & 39.24 & 19.79 & 6.87 & 2.35 & 0.41 \\
\hline No. plots & 4,370 & 4,370 & 3,269 & 2,678 & 2,213 & 1,936 \\
\hline Optimum aspect & NS & $27^{\circ}$ & $279^{\circ}$ & $194^{\circ}$ & NS & NS \\
\hline Amplitude & - & 0.10 & 0.07 & 0.20 & - & - \\
\hline
\end{tabular}

Table 11-Equations for determining the number of species on stocked plots. The form of the equation is $P=\left(1+e^{-\left(\Sigma \beta_{i} x_{i}\right)}\right)^{-1}$. The equation for one species is conditional on there being at least two trees on the plot, while other equations are conditional on the number of trees being equal to or greater than the number of species being predicted

${ }^{1}$ Represented as part of the constant term to avoid a singular matrix.

${ }^{2}$ Percent occurrence for dichotomous dependent variables is the percentage of plots on which the event occurred. For example, 1,763 of 4,370 stocked plots had only one species; therefore, percent occurrence is 40.34 . 
Table 12-Probability of occurrence for advance regeneration on stocked plots. The form of the $\theta$ quation is $P=\left(1+\theta^{-\left(2 \beta_{i} x_{i}\right)}\right)^{-1}$

\begin{tabular}{|c|c|c|c|c|c|c|c|c|c|c|}
\hline $\begin{array}{c}\text { Varlable } \\
(X)\end{array}$ & $\begin{array}{l}\text { Ponderosa } \\
\text { plne } \\
\text { (B) }\end{array}$ & $\begin{array}{l}\text { Wostern } \\
\text { larch } \\
(\beta)\end{array}$ & $\begin{array}{l}\text { Lodgepole } \\
\text { plne } \\
\text { ( } \beta \text { ) }\end{array}$ & $\begin{array}{c}\text { Engelmann } \\
\text { spruce } \\
(\beta)\end{array}$ & $\begin{array}{c}\text { Douglas- } \\
\text { fir } \\
\text { (B) }\end{array}$ & $\begin{array}{l}\text { White } \\
\text { pine } \\
(\beta)\end{array}$ & $\begin{array}{c}\text { Grand } \\
\text { fir } \\
(\beta)\end{array}$ & $\begin{array}{c}\text { Western } \\
\text { hemlock } \\
(\beta)\end{array}$ & $\begin{array}{c}\text { Subalpine } \\
\text { fir } \\
\text { ( } \beta)\end{array}$ & $\begin{array}{c}\text { Western } \\
\text { redcedar } \\
(\beta)\end{array}$ \\
\hline 1 Const: & 55 & 5.00929 & -7.88764 & -12.22361 & -0.69112 & -1.87330 & -2.84267 & -1.83783 & -14.92353 & $-0.3 c$ \\
\hline $2 \cos (A S P) * S L O$ & -2.53 & .25604 & 0 & 0 & -.22493 & -1.58 & 0 & & 280 & .6 \\
\hline 3 SIN(ASP)`SLO & -.59 & 1.59651 & 0 & 0 & -.46164 & -3.78659 & 0 & -.41924 & -.84457 & -1.01033 \\
\hline 4 SLO & -.55 & -.171 & -1.71254 & 0 & 1.39 & -3.9 & 1.36587 & -.03 & .08 & \\
\hline 5 'NONE & 0 & 0 & 0 & 0 & 0 & 0 & 0 & 0 & 0 & 0 \\
\hline $6 \mathrm{MECH}$ & -.56829 & 0 & 0 & -.75266 & -.91351 & -.89870 & -.99446 & -1.15450 & -.72264 & -.59370 \\
\hline $7 \mathrm{BUR}$ & -.726 & No data & 0 & -.95 & -1.596 & -.87 & -1.9 & -3.1 & -1.4 & -1.3 \\
\hline 8 ROAD & No data & No data & No data & -.14 & -1.26675 & No data & -1.36593 & -1.46549 & No data & -1.57013 \\
\hline 9 BAA & & 0 & 0 & 0 & & & & 0 & .00530 & .00575 \\
\hline $10 B A A^{2}$ & -.00024 & 0 & 0 & 0 & -.00008 & -.00031 & -.00003 & 0 & 0 & 0 \\
\hline $11 \ln (B A A)$ & 0 & 0 & .298 & 0 & 0 & 0 & 0 & 0 & 0 & 0 \\
\hline 12 ELEV & 0 & 0 & .045 & .27877 & -.01378 & .03855 & .16438 & 0 & .40971 & -.03900 \\
\hline 13 ELEV $^{2}$ & 0 & 0 & 0 & -.00200 & 0 & 0 & -.00208 & 0 & -.00330 & 0 \\
\hline 14 TIME & 0 & 0 & 0 & 0 & 0 & -.22848 & 0 & 0 & 0 & -.08 \\
\hline 15 REGT & -.1262 & 0 & 0 & -.092 & 0 & 0 & -.118 & 0 & -.06 & 0 \\
\hline 16 BWAF & & 0 & 0 & & 0 & 0 & -.10925 & 0 & -.05421 & 0 \\
\hline 17 BWB4 & 0 & 0 & 0 & & 0 & 0 & 0 & 0 & 0 & 0 \\
\hline 18 OVER & 1.05233 & 2.10395 & 2.47999 & 1.45230 & 1.00479 & .67217 & 1.05382 & 1.19186 & 1.66590 & 1.40441 \\
\hline 19 ВОТТОМ & 0 & 0 & 0 & 0 & 0 & 0 & 0 & 0 & 0 & 1.11039 \\
\hline
\end{tabular}

\section{Habltat type groups}

20 PSMENAGL
21 PSME/CARU
22 PSME/PHMA
23 PSME/SYAL
24 ABGR/LIBO
25 ABGRXETE
26 ABGR/CLUN
27 ABGR/SPBE
28 THPLAII
29 TSHE/AII
30 ABLANAGL
31 ABLAXETE
32 ABLACLUN
33 ABLAVCAGE
34 ABLAMEFE
35 ABLANCACA

National Forests

$\begin{array}{lll}0 & 0 & 1.93198 \\ 0 & 0 & 0 \\ 0 & 0 & 0 \\ 0 & 0 & 0 \\ -2.59212 & 1.49348 & 0 \\ -2.59212 & 0 & 1.32705 \\ -2.59212 & 0 & 1.32705 \\ -.70368 & 0 & 0 \\ -2.59212 & 0 & 0 \\ \text { No data } & 0 & 0 \\ \text { No data } & 0 & 1.93198 \\ \text { No data } & 1.49348 & 1.93198 \\ \text { No data } & 0 & 0 \\ \text { No data } & \text { No data } & 0 \\ \text { No data } & 0 & 1.32705 \\ \text { No data } & \text { No data } & 0\end{array}$

No data
No data
No data
No data
0
0
0
0
0
0

\begin{tabular}{|c|c|c|c|}
\hline 36 & Bitterroot & 0 & 0 \\
\hline 37 & Panhandle & 0 & 0 \\
\hline 38 & Clearwater & 0 & 0 \\
\hline 39 & Colville & 0 & 0 \\
\hline 40 & Deerlodge & 0 & 0 \\
\hline 41 & Flathead & No data & 0 \\
\hline 42 & Gallatin & No data & No data \\
\hline 43 & Helena & No data & No data \\
\hline 44 & Kootenai & 0 & 0 \\
\hline 45 & Lolo & 0 & 0 \\
\hline 46 & Nez Perce & 0 & 0 \\
\hline 47 & Payette & 1.53214 & 0 \\
\hline 48 & Boise & 1.53214 & No data \\
\hline
\end{tabular}

$\begin{array}{ll}0 & 0 \\ .89119 & 0 \\ .97238 & 0 \\ 0 & 0 \\ 0 & 0 \\ 0 & 0 \\ 0 & 0 \\ 0 & 0 \\ .94810 & 0 \\ .94810 & 0 \\ 0 & 0 \\ 1.14841 & 0 \\ 1.14841 & 0\end{array}$

Chi-square

16.39

Error mean square 0.7653

Percent occurrence

No. plots

2.81

Optimum aspect

3,456

$193^{\circ}$
0.37

$-.62002$

$-.62002$

$-1.15473$

$-1.15473$

$-2.12323$

$-2.30859$

$-1.36120$

$-.13552$

$-1.36120$

$-1.36120$

$-1.36120$

No data
No data

No data

No data

No data

0

No data

No data

No data

No data

.67412

$$
0
$$

0

$-.38890$

$-.70044$

$-.70044$

$-1.58770$

$-2.06589$

$-1.22480$

$-.42966$

No data

$-.42966$

No data

$-.89359$

$-.89359$

$-2.06589$

No data
No data

No data

No data

No data

No data

No data

No data

No data

No data

0

No data

No data

No data

No data

No data

No data
No data

No data

No data

No data

1.09193

0

No data

0

1.24962

1.69269

1.69269

1.69269

0

2.37496

2.37496
No data

No data

No data

No data

No data

No data

No data

No data

.65724

No data

No data

No data

No data

No data

No data

No data
0
0
-1.13793
No data
0
No data
No data
0
-1.13793
No data
No data
No data

11.75
1.0493
3.63
4,046
$247^{\circ}$
0.55

0
0
0
0
No data
0
No data
No data
0
0
0
0
0

21.37

0.9474

25.56

5,293

NS
No data

0

0

No data

No data

No data

No data

0

No data

No data

No data

26.19
0.9538
16.60
994
$354^{\circ}$
0.53

No data $-1.15548$

0

0

No data

No data

No data

No data

0

0

No data

No data

$\begin{array}{rr}30.01 & 20.87 \\ 0.9852 & 1.0074 \\ 8.62 & 16.29 \\ 4,813 & 2,326 \\ 285^{\circ} & 304^{\circ} \\ 0.13 & 0.30\end{array}$

'Represented as part of the constant term to avoid a singular matrix. 
Table 13-Probability of occurrence for subsequent regeneration. The form of the equation is $P=\left(1+\theta^{-\left(2 B, x_{1}\right)}\right)^{-1}$

\begin{tabular}{|c|c|c|c|c|c|c|c|c|c|c|}
\hline $\begin{array}{c}\text { Variable } \\
(X)\end{array}$ & $\begin{array}{l}\text { Ponderosa } \\
\text { pine } \\
(\beta)\end{array}$ & $\begin{array}{l}\text { Western } \\
\text { larch } \\
(\beta)\end{array}$ & $\begin{array}{l}\text { Lodgepole } \\
\text { pine } \\
\text { (ß) }\end{array}$ & $\begin{array}{c}\text { Engelmann } \\
\text { spruce } \\
(\beta)\end{array}$ & $\begin{array}{c}\text { Douglas- } \\
\text { fir } \\
(\beta)\end{array}$ & $\begin{array}{l}\text { White } \\
\text { pine } \\
(\beta)\end{array}$ & $\begin{array}{c}\text { Grand } \\
\text { fir } \\
(\beta)\end{array}$ & $\begin{array}{c}\text { Western } \\
\text { hemlock } \\
(\beta)\end{array}$ & $\begin{array}{c}\text { Subalpine } \\
\text { fir } \\
(\beta)\end{array}$ & $\begin{array}{c}\text { Western } \\
\text { redcedar } \\
(\beta)\end{array}$ \\
\hline 1 Constant & -3.92859 & -6.63750 & -0.96370 & -17.66672 & -2.62358 & 2.41585 & -4.21749 & -12.30531 & -7.73260 & -3.62791 \\
\hline $2 \operatorname{COS}(A S P) * S L O$ & -.71162 & 1.42144 & -.68409 & 1.52230 & .57720 & -.01901 & .77652 & 2.56422 & .87127 & 1.57737 \\
\hline $3 \mathrm{SIN}(\mathrm{ASP}) * \mathrm{SLO}$ & -.21418 & .77954 & -.18537 & 1.00295 & -.02488 & -1.38626 & .87180 & -.43928 & .43295 & .73797 \\
\hline 4 SLO & -.65401 & -.49261 & -3.19743 & -2.05762 & .27942 & -1.83669 & -.45507 & -1.40517 & -1.75130 & -1.79633 \\
\hline $5^{1}$ NONE & 0 & 0 & 0 & 0 & 0 & 0 & 0 & 0 & 0 & 0 \\
\hline $6 \mathrm{MECH}$ & .67888 & .98315 & .64040 & 1.15332 & .22750 & .15480 & .18407 & .22827 & .22322 & .63192 \\
\hline 7 BURN & .74077 & 1.12968 & .38122 & 1.09008 & .44157 & .02302 & .04756 & .62188 & .13249 & 1.06553 \\
\hline $8 \mathrm{ROAD}$ & .85366 & 1.51324 & .79282 & 1.47729 & .60009 & .55174 & .56605 & .65690 & .93574 & 1.44289 \\
\hline $9 \mathrm{BAA}$ & 0 & -.00973 & -.03176 & 0 & -.00587 & -.00963 & -.00453 & 0 & -.01123 & -.00399 \\
\hline $10 \ln (B A A)$ & -.33190 & 0 & 0 & -.24045 & 0 & 0 & 0 & 0 & 0 & 0 \\
\hline 11 ELEV & -.03701 & .12605 & 0 & 0 & -.02291 & -.04806 & .13693 & .45343 & .05264 & -.02599 \\
\hline 12 ELEV$^{2}$ & 0 & -.00170 & 0 & 0 & 0 & 0 & -.00175 & -.00583 & 0 & 0 \\
\hline $13 \ln (E L E V)$ & 0 & 0 & 0 & 3.17337 & 0 & 0 & 0 & 0 & 0 & 0 \\
\hline 14 TIME $^{1 / 2}$ & .46035 & 0 & 0 & 0 & 0 & .58166 & 0 & .74555 & 0 & .92474 \\
\hline 15 SQREGT & 0 & 0 & 0 & .55794 & .61203 & 0 & .55587 & 0 & .54995 & 0 \\
\hline 16 SQBWAF & 0 & 0 & 0 & .71901 & .55493 & 0 & .41238 & 0 & .48266 & 0 \\
\hline 17 BWB4 & 0 & 0 & 0 & 0 & 0 & 0 & -.24985 & 0 & 0 & 0 \\
\hline 18 OVER & 1.07701 & 1.10264 & 1.58270 & 1.30915 & .23505 & 1.15252 & .27597 & .77804 & .57990 & .99736 \\
\hline 19 PLANT & 1.43545 & 1.18734 & .86778 & 1.79176 & .83804 & 1.80834 & .63057 & 0 & .68549 & 0 \\
\hline 20 BOTTOM & 0 & 0 & .72550 & 0 & 0 & 0 & 0 & 0 & 0 & 0 \\
\hline 21 UPPER & .34694 & 0 & 0 & 0 & 0 & 0 & 0 & 0 & 0 & 0 \\
\hline 22 RIDGE & .34694 & 0 & 0 & 0 & 0 & 0 & 0 & 0 & 0 & 0 \\
\hline \multicolumn{11}{|l|}{ Habitat type groups } \\
\hline 23 PSMENAGL & 0 & .66031 & .40172 & No data & 0 & No data & No data & No data & No data & No data \\
\hline 24 PSME/CARU & .65576 & 0 & .40172 & No data & 0 & No data & No data & No data & No data & No data \\
\hline 25 PSME/PHMA & .65576 & 0 & -.77148 & No data & 0 & No data & No data & No data & No data & No data \\
\hline $26 \mathrm{PSME} / \mathrm{SYAL}$ & .65576 & 0 & -.77148 & No data & 0 & No data & No data & No data & No data & No data \\
\hline 27 ABGR/LIBO & -.39399 & .66031 & 0 & .34244 & 0 & 0 & 0 & No data & 0 & No data \\
\hline 28 ABGR/XETE & 0 & .66031 & .67108 & .34244 & 0 & 0 & -.21632 & No data & 0 & No data \\
\hline 29 ABGR/CLUN & -.39399 & 0 & 0 & -.79350 & 0 & 0 & 0 & No data & 0 & No data \\
\hline $30 \mathrm{ABGR} / \mathrm{SPBE}$ & .65576 & 0 & -.77148 & -.79350 & 0 & 0 & 0 & No data & No data & No data \\
\hline 31 THPL/All & No data & .74374 & -.54311 & 0 & 0 & .65722 & .22883 & No data & 0 & 0 \\
\hline 32 TSHE/All & No data & .89597 & -.08682 & .21151 & 0 & 1.03756 & 0 & 0 & 1.28599 & -.64033 \\
\hline 33 ABLANAGL & No data & .73817 & 1.73217 & .09543 & -1.10811 & No data & -2.44230 & No data & 1.03643 & No data \\
\hline 34 ABLAXXTE & No data & .73817 & .67108 & .09543 & -.18290 & 0 & -2.44230 & No data & 1.03643 & No data \\
\hline 35 ABLAVCLUN & No data & .73817 & -.63157 & .09543 & -.18290 & 0 & -.81250 & No data & 2.44933 & No data \\
\hline 36 ABLAVCAGE & No data & No data & 1.73217 & .09543 & -1.10811 & No data & -2.44230 & No data & 1.03643 & No data \\
\hline 37 ABLAMMEFE & No data & .73817 & .43158 & .55866 & -1.10811 & 0 & -2.44230 & No data & 2.44933 & No data \\
\hline 38 ABLAVCACA & No data & No data & -.63157 & .55866 & No data & No data & No data & No data & 2.44933 & No data \\
\hline \multicolumn{11}{|l|}{ National Forests } \\
\hline 39 Bitterroot & 2.48159 & 0 & 0 & -.52561 & .61952 & No data & -1.80142 & No data & 0 & No data \\
\hline 40 Panhandle & 0 & 0 & -1.41402 & 1.10987 & 0 & 0 & 0 & 0 & 0 & 0 \\
\hline 41 Clearwater & 0 & 0 & -1.41402 & .97309 & 0 & 0 & 0 & 0 & 0 & 0 \\
\hline 42 Colville & 0 & 0 & 0 & 0 & .61952 & -1.54687 & 0 & 0 & 0 & 0 \\
\hline 43 Deerlodge & 0 & 1.87274 & 0 & .31152 & .61952 & No data & No data & No data & 0 & No data \\
\hline 44 Flathead & No data & 1.87274 & 0 & .31152 & .61952 & -1.54687 & -1.80142 & No data & 0 & No data \\
\hline 45 Gallatin & No data & No data & 0 & -.52561 & .61952 & No data & No data & No data & 0 & No data \\
\hline 46 Helena & No data & No data & 0 & -.52561 & .61952 & No data & No data & No data & 0 & No data \\
\hline 47 Kootenai & 2.48159 & 1.87274 & 0 & 2.31698 & 0 & 0 & -1.10737 & 0 & .81375 & 0 \\
\hline 48 Lolo & 1.87642 & 1.87274 & 0 & 0 & 0 & -1.54687 & -1.10737 & 0 & .81375 & 0 \\
\hline 49 Nez Perce & 1.87642 & 0 & -1.41402 & .91425 & 0 & No data & 0 & No data & 0 & 0 \\
\hline 50 Payette & 2.48159 & 0 & -1.41402 & -.39580 & -.66350 & No data & -1.10737 & No data & 0 & No data \\
\hline 51 Boise & 2.48159 & No data & 0 & .74387 & -.66350 & No data & -1.10737 & No data & 0 & No data \\
\hline Chi-square & 26.51 & 17.49 & 53.94 & 34.66 & 38.80 & 24.18 & 19.81 & 9.63 & 21.83 & 12.26 \\
\hline Error mean square & 1.0310 & 0.9899 & 1.0079 & 0.9609 & 0.9620 & 1.1176 & 1.0041 & 0.9923 & 1.0842 & 1.0015 \\
\hline Percent occurrence & e $\quad 13.21$ & 8.23 & 10.18 & 8.96 & 20.22 & 7.81 & 35.61 & 26.16 & 8.06 & 15.69 \\
\hline No. plots & 3,664 & 5,712 & 6,250 & 5,494 & 6,191 & 4,326 & 5,293 & 994 & 5,125 & 2,326 \\
\hline Optimum aspect & $197^{\circ}$ & $29^{\circ}$ & $195^{\circ}$ & $33^{\circ}$ & $258^{\circ}$ & $269^{\circ}$ & $48^{\circ}$ & $350^{\circ}$ & $26^{\circ}$ & $25^{\circ}$ \\
\hline Amplitude & 0.11 & 0.24 & 0.11 & 0.27 & 0.09 & 0.21 & 0.17 & 0.37 & 0.14 & 0.26 \\
\hline
\end{tabular}

'Represented as part of the constant term to avoid a singular matrix. 
Table 14-Probability of occurrence for excess regeneration. The form of the equation is $P=\left(1+e^{-\left(\Sigma \beta_{i} x_{j}\right.}\right)^{-1}$

\begin{tabular}{|c|c|c|c|c|c|c|c|c|c|c|}
\hline $\begin{array}{c}\text { Variable } \\
(X)\end{array}$ & $\begin{array}{l}\text { Ponderosa } \\
\text { pine } \\
(\beta)\end{array}$ & $\begin{array}{l}\text { Western } \\
\text { larch } \\
(\beta)\end{array}$ & $\begin{array}{l}\text { Lodgepole } \\
\text { pine } \\
(\beta)\end{array}$ & $\begin{array}{c}\text { Engelmann } \\
\text { spruce } \\
(\beta)\end{array}$ & $\begin{array}{c}\text { Douglas- } \\
\text { fir } \\
(\beta)\end{array}$ & $\begin{array}{l}\text { White } \\
\text { pine } \\
(\beta)\end{array}$ & $\begin{array}{l}\text { Grand } \\
\text { fir } \\
(\beta)\end{array}$ & $\begin{array}{c}\text { Western } \\
\text { hemlock } \\
(\beta)\end{array}$ & $\begin{array}{c}\text { Subalpine } \\
\text { fir } \\
(\beta)\end{array}$ & $\begin{array}{c}\text { Western } \\
\text { redcedar } \\
(\beta)\end{array}$ \\
\hline 1 Constant $\quad-1$ & $-18.89119-$ & -15.25330 & -2.56629 & -26.32721 & -2.00802 & -2.66011 & -6.14484 & -9.31954 & -7.40720 & -1.29179 \\
\hline $2 \cos (A S P)^{*} S L O$ & 0 & 1.58775 & 1.07703 & 0 & -0.13516 & -.21036 & 1.47745 & 4.31678 & 1.03636 & 1.96111 \\
\hline 3 SIN(ASP)*SLO & 0 & .44217 & -.20678 & 0 & -.39445 & -2.17665 & .26161 & -.90111 & .28255 & -.08096 \\
\hline 4 SLO & 0 & -1.50273 & -1.75710 & -1.95903 & .85319 & -2.61597 & -.47692 & -.13394 & -1.52018 & -.67317 \\
\hline 5 'NONE & 0 & 0 & 0 & 0 & 0 & 0 & 0 & 0 & 0 & 0 \\
\hline $6 \mathrm{MECH}$ & 0 & .75803 & .05479 & .99041 & -.41157 & 0 & -.42492 & -.26230 & -.50965 & -.06477 \\
\hline 7 BURN & 0 & .67282 & -.61241 & .54089 & -.49398 & 0 & -.83001 & -.56556 & -.81329 & .18186 \\
\hline $8 \mathrm{ROAD}$ & 0 & 1.92937 & -.47796 & 1.52932 & .03980 & 0 & -.21219 & -.18974 & .21813 & .53623 \\
\hline 9 BAA & 0 & 0 & 0 & 0 & 0 & -.01703 & -.00489 & 0 & 0 & 0 \\
\hline $10 \ln (B A A)$ & 0 & 0 & -.36016 & 0 & 0 & .31670 & .13567 & 0 & 0 & 0 \\
\hline 11 ELEV & .66069 & .43849 & -.21089 & .74546 & -.03835 & 0 & .27891 & .39648 & .05698 & -.03679 \\
\hline 12 ELEV $^{2}$ & -.00690 & -.00513 & .00224 & -.00650 & 0 & 0 & -.00366 & -.00559 & 0 & 0 \\
\hline 13 TIME & 0 & 0 & 0 & .07038 & .06521 & 0 & 0 & .08965 & 0 & .07178 \\
\hline 14 REGT & 0 & 0 & 0 & 0 & 0 & 0 & .05824 & 0 & 0 & 0 \\
\hline 15 BWAF & 0 & 0 & 0 & 0 & 0 & 0 & .05026 & 0 & 0 & 0 \\
\hline 16 BWB4 & 0 & 0 & 0 & 0 & 0 & 0 & 0 & 0 & -.19509 & 0 \\
\hline 17 OVER & .91178 & 1.28724 & 2.65674 & 1.22240 & .73419 & 1.05466 & .43489 & 1.02526 & 1.50977 & 1.39996 \\
\hline 18 ВОТТОМ & 0 & 0 & 1.05209 & 0 & 0 & 0 & 0 & 0 & 0 & 0 \\
\hline \multicolumn{11}{|l|}{ Habitat type groups } \\
\hline 19 PSMENAGL & 0 & 1.05732 & 0 & No data & .78603 & No data & No data & No data & No data & No data \\
\hline 20 PSME/CARU & 0 & 0 & 0 & No data & .78603 & No data & No data & No data & No data & No data \\
\hline 21 PSME/PHMA & 0 & 0 & -1.66484 & No data & 0 & No data & No data & No data & No data & No data \\
\hline 22 PSME/SYAL & 0 & 0 & -.48823 & No data & 0 & No data & No data & No data & No data & No data \\
\hline 23 ABGR/LIBO & -.80025 & 1.05732 & -.48823 & 0 & 0 & -.67461 & 0 & No data & 0 & No data \\
\hline 24 ABGR/XETE & -.80025 & 1.05732 & -.48823 & 0 & 0 & -.67461 & -1.14939 & No data & 0 & No data \\
\hline 25 ABGR/CLUN & -1.63194 & .43319 & -.48823 & .92664 & 0 & 0 & -.55579 & No data & 0 & No data \\
\hline 26 ABGR/SPBE & -.80025 & 0 & -1.66484 & 0 & -.60779 & -.67461 & -1.14939 & No data & No data & No data \\
\hline 27 THPL/All & -1.90005 & .43319 & -1.89424 & 1.85920 & 0 & 0 & 0 & No data. & 0 & 0 \\
\hline 28 TSHE/All & No data & 1.20503 & -.71352 & 2.33304 & .49310 & 0 & 0 & 0 & 2.10127 & -.43570 \\
\hline 29 ABLANAGL & No data & 1.55633 & .65440 & .61242 & -.63641 & No data & -2.43159 & No data & 1.80532 & No data \\
\hline 30 ABLA XETE & No data & 1.55633 & .65440 & .61242 & .52193 & -.67461 & -2.43159 & No data & 1.80532 & No data \\
\hline 31 ABLAVCLUN & No data & 1.55633 & -.58735 & 1.85230 & 0 & -.67461 & -.88282 & No data & 3.37135 & No data \\
\hline 32 ABLA/CAGE & No data & No data & .65440 & 0 & -.63641 & No data & -2.43159 & No data & 0 & No data \\
\hline 33 ABLAMEFE & No data & 1.55633 & -.58735 & 1.85230 & 0 & 0 & -2.43159 & No data & 3.37135 & No data \\
\hline 34 ABLANCACA & No data & No data & -.58735 & 1.85230 & No data & No data & No data & No data & 2.10127 & No data \\
\hline \multicolumn{11}{|l|}{ National Forests } \\
\hline 35 Bitterroot & 0 & 0 & 0 & 0 & 1.31556 & No data & 0 & No data & 1.20278 & No data \\
\hline 36 Panhandle & 0 & 0 & 0 & 0 & 0 & 0 & 0 & 0 & 0 & 0 \\
\hline 37 Clearwater & 0 & 0 & 0 & 0 & 0 & -.56300 & 0 & 0 & 0 & 0 \\
\hline 38 Colville & 0 & 0 & 0 & 0 & 0 & -1.86484 & 0 & 0 & 0 & 0 \\
\hline 39 Deerlodge & 0 & 2.39893 & 0 & 0 & 1.31556 & No data & No data & No data & 1.20278 & No data \\
\hline 40 Flathead & No data & 2.39893 & 0 & 0 & 0 & -1.86484 & 0 & No data & 1.20278 & No data \\
\hline 41 Gallatin & No data & No data & 0 & 0 & 0 & No data & No data & No data & 1.20278 & No data \\
\hline 42 Helena & No data & No data & 0 & 0 & 1.31556 & No data & No data & No data & 1.20278 & No data \\
\hline 43 Kootenai & 0 & 2.39893 & 0 & 0 & 0 & 0 & -.51882 & 0 & 1.20278 & 0 \\
\hline 44 Lolo & 0 & 2.39893 & 0 & 0 & 1.31556 & -1.86484 & -.51882 & 0 & 1.20278 & 0 \\
\hline 45 Nez Perce & 0 & 0 & 0 & 0 & 0 & No data & 0 & No data & 0 & 0 \\
\hline 46 Payette & 0 & 0 & 0 & 0 & 0 & No data & -.76811 & No data & 0 & No data \\
\hline 47 Boise & 0 & No data & 0 & 0 & 0 & No data & -.76811 & No data & 0 & No data \\
\hline Chi-square & 0.52 & 8.96 & 20.94 & 9.00 & 23.69 & 2.04 & 29.27 & 18.43 & 29.83 & 10.24 \\
\hline Error mean square & e 0.9178 & 1.1135 & 0.9397 & 1.3310 & 0.9934 & 0.9455 & 1.0388 & 0.9774 & 0.7717 & 0.9845 \\
\hline Percent occurrence & ce $\quad 1.47$ & 2.78 & 4.45 & 2.60 & 10.32 & 3.33 & 24.90 & 24.95 & 6.56 & 16.72 \\
\hline No. plots & 3,664 & 5,712 & 6,250 & 5,494 & 6,191 & 4,326 & 5,293 & 994 & 5,125 & 2,326 \\
\hline Optimum aspect & NS & $16^{\circ}$ & $349^{\circ}$ & NS & $251^{\circ}$ & $264^{\circ}$ & $10^{\circ}$ & $358^{\circ}$ & $15^{\circ}$ & $358^{\circ}$ \\
\hline Amplitude & - & 0.24 & 0.16 & - & 0.06 & 0.32 & 0.22 & 0.58 & 0.16 & 0.29 \\
\hline
\end{tabular}

'Represented as part of the constant term to avoid a singular matrix. 
Table 15-Weibull distribution functions for determining delay to germination for advance best trees. The form of the equation is DELAY $=B[-\ln (1-X)]^{1 / C}+1$. Categories left blank use the corresponding coefficient for no budworm. " $X$ " is a random number drawn from a uniformly distributed pseudo-random number generator. BWB4 is the number of budworm years in the 5 years before the last disturbance. BAA is the plot residual overstory area, reset to 1.0 if 0.0

\begin{tabular}{|c|c|c|c|c|c|c|}
\hline \multirow[b]{3}{*}{ Species } & \multicolumn{6}{|c|}{ BWB4 (No. years) and BAA ( $\left.\mathrm{ft}^{2} / a c r e\right)$} \\
\hline & \multicolumn{2}{|c|}{ None } & \multicolumn{2}{|c|}{1.3} & \multicolumn{2}{|c|}{$4-5$} \\
\hline & 0.25 & $26+$ & $0-25$ & 26+ & 0.25 & 26+ \\
\hline $\begin{array}{l}\text { Ponderosa } \\
\text { pine }\end{array}$ & $\begin{array}{l}B=8.98612 \\
C=1.06847\end{array}$ & $\begin{array}{r}10.31266 \\
1.47040\end{array}$ & & & & \\
\hline $\begin{array}{l}\text { Western } \\
\text { larch }\end{array}$ & $\begin{array}{l}B=9.76822 \\
C=1.15258\end{array}$ & $\begin{array}{r}27.10024 \\
1.31969\end{array}$ & & & & \\
\hline $\begin{array}{l}\text { Lodgepole } \\
\text { pine }\end{array}$ & $\begin{array}{l}B=7.35888 \\
C=\quad .91230\end{array}$ & $\begin{array}{r}32.95581 \\
1.23054\end{array}$ & & & & \\
\hline $\begin{array}{l}\text { Engelmann } \\
\text { spruce }\end{array}$ & $\begin{array}{l}B=13.99027 \\
C=1.05130\end{array}$ & $\begin{array}{r}21.77936 \\
1.41622\end{array}$ & $\begin{array}{l}8.38820 \\
1.33278\end{array}$ & $\begin{array}{r}18.02341 \\
1.50228\end{array}$ & $\begin{array}{r}10.58744 \\
1.47050\end{array}$ & $\begin{array}{r}16.55466 \\
1.20740\end{array}$ \\
\hline $\begin{array}{l}\text { Douglas- } \\
\text { fir }\end{array}$ & $\begin{array}{l}B=13.12102 \\
C=1.04325\end{array}$ & $\begin{array}{r}22.18654 \\
1.21565\end{array}$ & $\begin{array}{r}16.85625 \\
1.16545\end{array}$ & $\begin{array}{r}18.60110 \\
1.18251\end{array}$ & $\begin{array}{r}18.83308 \\
1.30720\end{array}$ & $\begin{array}{r}17.66096 \\
1.93848\end{array}$ \\
\hline $\begin{array}{l}\text { White } \\
\text { pine }\end{array}$ & $\begin{array}{l}B=6.69983 \\
C=1.26253\end{array}$ & $\begin{array}{r}13.43118 \\
1.27930\end{array}$ & & & & \\
\hline $\begin{array}{l}\text { Grand } \\
\text { fir }\end{array}$ & $\begin{array}{l}B=11.26918 \\
C=1.12214\end{array}$ & $\begin{array}{r}18.24566 \\
1.08280\end{array}$ & $\begin{array}{r}11.39304 \\
1.13703\end{array}$ & $\begin{array}{r}19.99433 \\
1.35577\end{array}$ & $\begin{array}{r}16.15405 \\
1.33030\end{array}$ & $\begin{array}{r}13.93679 \\
1.31178\end{array}$ \\
\hline $\begin{array}{l}\text { Western } \\
\text { hemlock }\end{array}$ & $\begin{array}{l}B=13.60459 \\
C=1.26706\end{array}$ & $\begin{array}{r}19.60548 \\
1.28744\end{array}$ & & & & \\
\hline $\begin{array}{l}\text { Subalpine } \\
\text { fir }\end{array}$ & $\begin{array}{l}B=21.96234 \\
C=1.10127\end{array}$ & $\begin{array}{r}32.17673 \\
1.31702\end{array}$ & $\begin{array}{r}20.20766 \\
1.66050\end{array}$ & $\begin{array}{r}30.05268 \\
1.83254\end{array}$ & $\begin{array}{r}25.51236 \\
1.87195\end{array}$ & $\begin{array}{r}20.55520 \\
1.24878\end{array}$ \\
\hline $\begin{array}{l}\text { Western } \\
\text { redcedar }\end{array}$ & $\begin{array}{l}B=17.77938 \\
C=1.33722\end{array}$ & $\begin{array}{r}24.24134 \\
1.54066\end{array}$ & & & & \\
\hline
\end{tabular}


Table 16-Equations predicting heights of advance regeneration. The form of the equation is $H T=\theta^{\left(2 \beta_{i} x_{i}\right)}$

\begin{tabular}{|c|c|c|c|c|c|c|c|c|c|c|}
\hline $\begin{array}{l}\text { Varlable } \\
(x)\end{array}$ & $\begin{array}{c}\text { Ponderosa } \\
\text { plne } \\
(\beta)\end{array}$ & $\begin{array}{l}\text { Western } \\
\text { larch } \\
(\beta)\end{array}$ & $\begin{array}{l}\text { Lodgepole } \\
\text { plne } \\
(\beta)\end{array}$ & $\begin{array}{c}\text { Engelmann } \\
\text { spruce } \\
\text { ( } \beta \text { ) }\end{array}$ & $\begin{array}{c}\text { Douglas- } \\
\text { flr } \\
(\beta)\end{array}$ & $\begin{array}{l}\text { Whlte } \\
\text { plne } \\
(\beta)\end{array}$ & $\begin{array}{c}\text { Grand } \\
\text { fir } \\
(\beta)\end{array}$ & $\begin{array}{c}\text { Western } \\
\text { hemlock } \\
(\beta)\end{array}$ & $\begin{array}{c}\text { Subalpine } \\
\text { fir } \\
(\beta)\end{array}$ & $\begin{array}{c}\text { Western } \\
\text { redcedar } \\
\text { (B) }\end{array}$ \\
\hline 1 Constant & -1.52746 & -1.65811 & -1.12979 & -2.19638 & -1.21096 & 0.05586 & -2.26623 & -0.70341 & -1.88857 & 2.51134 \\
\hline $2 \ln (\mathrm{AGE})$ & .86174 & 1.15051 & .91553 & 1.12147 & 1.07594 & .84765 & 1.02574 & .78900 & .86013 & .73744 \\
\hline $3 \cos (\mathrm{ASP}) * \mathrm{SLO}$ & 0 & 0 & .85450 & 0 & 0 & -.79566 & -.06822 & 0 & 0 & -.08761 \\
\hline $4 \operatorname{SIN}(A S P) * S L O$ & 0 & 0 & .51484 & 0 & 0 & .39278 & .15558 & 0 & 0 & .71709 \\
\hline 5 SLO & 0 & 0 & .61714 & 0 & 0 & -.68673 & -.11461 & 0 & .57899 & -.54406 \\
\hline 6 ELEV & 0 & 0 & 0 & 0 & -.05148 & -.02835 & 0 & 0 & 0 & -.20298 \\
\hline $7 \mathrm{ELEV}^{2}$ & 0 & 0 & 0 & 0 & .00047 & 0 & 0 & 0 & 0 & .00263 \\
\hline $8 \mathrm{BAA}$ & 0 & 0 & 0 & -.00227 & 0 & -.00382 & -.00227 & -.00322 & 0 & 0 \\
\hline $9 \ln (T P S P)$ & .16174 & 0 & 0 & 0 & .14822 & 0 & .16706 & .07903 & .12095 & .18618 \\
\hline 10 'NONE & 0 & 0 & 0 & 0 & 0 & 0 & 0 & 0 & 0 & 0 \\
\hline $11 \mathrm{MECH}$ & 0 & 0 & 0 & 0 & 0 & 0 & 0 & -.09283 & -.17341 & 0 \\
\hline 12 BURN & 0 & 0 & 0 & 0 & 0 & 0 & 0 & -1.16 & -.05 & 0 \\
\hline $13 \mathrm{ROAD}$ & 0 & 0 & 0 & 0 & 0 & 0 & 0 & -.35348 & .14310 & 0 \\
\hline 14 BWB4 & 0 & 0 & 0 & 0 & 0 & 0 & -.04666 & 0 & -.0 & 0 \\
\hline 15 BWAF & .07136 & 0 & 0 & 0 & 0 & 0 & -.01745 & 0 & 0 & 0 \\
\hline 16 ВОTТОМ & 0 & 0 & 0 & 0 & .00895 & 0 & 0 & 0 & 0 & 0 \\
\hline 17 LOWER & 0 & 0 & 0 & 0 & .40658 & 0 & 0 & 0 & 0 & 0 \\
\hline 18 MIDSLOPE & 0 & 0 & 0 & 0 & .21454 & 0 & 0 & 0 & 0 & 0 \\
\hline 19 UPPER & 0 & 0 & 0 & 0 & .210 & 0 & 0 & 0 & 0 & 0 \\
\hline $20^{\prime}$ RIDGE & 0 & 0 & 0 & 0 & 0 & 0 & 0 & 0 & 0 & 0 \\
\hline \multicolumn{11}{|l|}{ Habitat type groups } \\
\hline $21{ }^{2}$ Dry PSME & 0 & 0 & 0 & No data & .17475 & No data & No data & No data & No data & No data \\
\hline $22{ }^{3}$ Moist PSME & 0 & 0 & 0 & No data & .02195 & No data & No data & No data & No data & No data \\
\hline 23 ABGR & 0 & 0 & 0 & 0 & .15324 & 0 & .22537 & No data & No data & No data \\
\hline 24 THPLTSHE & 0 & 0 & 0 & 0 & .14169 & 0 & .25708 & 0 & No data & 0 \\
\hline $25{ }^{\prime} A B L A$ & 0 & 0 & 0 & 0 & 0 & 0 & 0 & No data & 0 & No data \\
\hline F-ratio & 40.70 & 57.53 & 42.85 & 109.32 & 92.65 & 25.52 & 213.38 & 24.46 & 82.48 & 40.35 \\
\hline R-square & 0.4806 & 0.4979 & 0.4459 & 0.5430 & 0.5031 & 0.5002 & 0.4936 & 0.3690 & 0.4716 & 0.3013 \\
\hline No. trees & 136 & 60 & 218 & 187 & 1,111 & 160 & 2,200 & 258 & 655 & 663 \\
\hline Optimum aspect & NS & NS & $31^{\circ}$ & NS & NS & $154^{\circ}$ & $114^{\circ}$ & NS & NS & $97^{\circ}$ \\
\hline Ámplitude & - & - & 1.82 & - & - & 1.70 & 1.11 & - & - & 1.54 \\
\hline
\end{tabular}

'Represented as part of the constant term to avoid a singular matrix.

2Dry Pseudotsuga menziesii (habitat type group 1).

${ }^{3}$ Moist Pseudotsuga menziesii (habitat type groups 2, 3, and 4).

${ }^{4} \mathrm{Height}$ at the optimum aspect divided by height at the poorest aspect. 
Table 17-Weibull distribution functions for determining delay to germination for subsequent best trees. The form of the equation is DELAY $=B[-\ln (1-X)]^{1 / C}+1$. Categories left blank use the corresponding coefficient for the 0-2 year budworm category. " $X$ " is a random number drawn from a uniformly distributed pseudo-random number generator. BWAF is the number of years since the last disturbance with budworm

\begin{tabular}{|c|c|c|c|c|c|c|}
\hline \multirow[b]{3}{*}{ Species } & \multicolumn{6}{|c|}{ Years since disturbance and BWAF } \\
\hline & \multicolumn{2}{|c|}{ TIME $=2.7 \mathrm{yr}$} & \multicolumn{2}{|c|}{ TIME = 8-12 yr } & \multicolumn{2}{|c|}{ TIME = 13+ yr } \\
\hline & $0.2 \mathrm{yr}$ & $3+y r$ & $0-2 \mathrm{yr}$ & $3+y r$ & $0.2 \mathrm{yr}$ & $3+y r$ \\
\hline $\begin{array}{l}\text { Ponderosa } \\
\text { pine }\end{array}$ & $\begin{array}{l}B=3.81610 \\
C=3.01975\end{array}$ & & $\begin{array}{l}5.74622 \\
2.09376\end{array}$ & & $\begin{array}{l}9.36345 \\
1.80925\end{array}$ & \\
\hline $\begin{array}{l}\text { Western } \\
\text { larch }\end{array}$ & $\begin{array}{l}B=5.23792 \\
C=3.11598\end{array}$ & & $\begin{array}{l}7.38005 \\
3.04038\end{array}$ & & $\begin{array}{r}10.42350 \\
2.87196\end{array}$ & \\
\hline $\begin{array}{l}\text { Lodgepole } \\
\text { pine }\end{array}$ & $\begin{array}{l}B=5.33757 \\
C=4.16994\end{array}$ & & $\begin{array}{l}6.78727 \\
3.59937\end{array}$ & & $\begin{array}{l}9.45827 \\
2.39138\end{array}$ & \\
\hline $\begin{array}{l}\text { Engelmann } \\
\text { spruce }\end{array}$ & $\begin{array}{l}B=5.36466 \\
C=2.89777\end{array}$ & $\begin{array}{l}5.92251 \\
3.31325\end{array}$ & $\begin{array}{l}7.44468 \\
2.80504\end{array}$ & $\begin{array}{l}8.62548 \\
5.21269\end{array}$ & $\begin{array}{l}9.69507 \\
3.27745\end{array}$ & $\begin{array}{l}8.76074 \\
2.30270\end{array}$ \\
\hline $\begin{array}{l}\text { Douglas- } \\
\text { fir }\end{array}$ & $\begin{array}{l}B=4.34376 \\
C=2.33194\end{array}$ & $\begin{array}{l}4.01218 \\
2.16561\end{array}$ & $\begin{array}{l}6.55916 \\
2.63560\end{array}$ & $\begin{array}{l}5.86172 \\
2.16010\end{array}$ & $\begin{array}{l}9.16226 \\
2.21663\end{array}$ & $\begin{array}{r}10.61297 \\
2.44953\end{array}$ \\
\hline $\begin{array}{l}\text { White } \\
\text { pine }\end{array}$ & $\begin{array}{l}B=3.52946 \\
C=1.71621\end{array}$ & & $\begin{array}{l}7.62339 \\
2.72466\end{array}$ & & $\begin{array}{r}12.79801 \\
3.98359\end{array}$ & \\
\hline $\begin{array}{l}\text { Grand } \\
\text { fir }\end{array}$ & $\begin{array}{l}B=4.17909 \\
C=2.47058\end{array}$ & $\begin{array}{l}3.67409 \\
2.19139\end{array}$ & $\begin{array}{l}5.88262 \\
2.25957\end{array}$ & $\begin{array}{l}6.12256 \\
2.38522\end{array}$ & $\begin{array}{l}8.49857 \\
2.00065\end{array}$ & $\begin{array}{l}8.74195 \\
2.03146\end{array}$ \\
\hline $\begin{array}{l}\text { Western } \\
\text { hemlock }\end{array}$ & $\begin{array}{l}B=4.33094 \\
C=1.97408\end{array}$ & & $\begin{array}{l}6.30802 \\
2.35053\end{array}$ & & $\begin{array}{l}8.63060 \\
2.00997\end{array}$ & \\
\hline $\begin{array}{l}\text { Subalpine } \\
\text { fir }\end{array}$ & $\begin{array}{l}B=3.45725 \\
C=2.06804\end{array}$ & $\begin{array}{l}4.11555 \\
1.98007\end{array}$ & $\begin{array}{l}6.34975 \\
2.79933\end{array}$ & $\begin{array}{l}6.19124 \\
2.84149\end{array}$ & $\begin{array}{l}8.65545 \\
2.28687\end{array}$ & $\begin{array}{l}8.82962 \\
2.46665\end{array}$ \\
\hline $\begin{array}{l}\text { Western } \\
\text { redcedar }\end{array}$ & $\begin{array}{l}B=4.16284 \\
C=2.03892\end{array}$ & & $\begin{array}{l}7.52536 \\
3.12279\end{array}$ & & $\begin{array}{r}10.20937 \\
2.68340\end{array}$ & \\
\hline
\end{tabular}


Table 18-Equations predicting heights of subsequent regeneration. The form of the equation is $H T=\theta^{\left(2 \beta_{1}, x_{t}\right)}$

\begin{tabular}{|c|c|c|c|c|c|c|c|c|c|c|}
\hline $\begin{array}{c}\text { Variable } \\
(X)\end{array}$ & $\begin{array}{c}\text { Ponderosa } \\
\text { pine } \\
(\beta)\end{array}$ & $\begin{array}{l}\text { Western } \\
\text { larch } \\
(\beta)\end{array}$ & $\begin{array}{l}\text { Lodgepole } \\
\text { pine } \\
(\beta)\end{array}$ & $\begin{array}{c}\text { Engelmann } \\
\text { spruce } \\
(\beta)\end{array}$ & $\begin{array}{c}\text { Douglas- } \\
\text { fir } \\
(\beta)\end{array}$ & $\begin{array}{l}\text { White } \\
\text { pine } \\
(\beta)\end{array}$ & $\begin{array}{c}\text { Grand } \\
\text { fir } \\
(\beta)\end{array}$ & $\begin{array}{c}\text { Western } \\
\text { hemlock } \\
(\beta)\end{array}$ & $\begin{array}{c}\text { Subalpine } \\
\text { fir } \\
(\beta)\end{array}$ & $\begin{array}{c}\text { Western } \\
\text { redcedar } \\
(\beta)\end{array}$ \\
\hline 1 Constant & 0.07492 & -1.47708 & -0.66776 & -2.79250 & -2.21695 & -1.86747 & -2.51730 & -2.52415 & -2.29466 & -1.40304 \\
\hline $2 \ln (A G E)$ & 1.43793 & 1.19295 & 1.25739 & 1.40463 & 1.22826 & 1.27309 & 1.07561 & 1.41312 & 1.11917 & .95548 \\
\hline $3 \cos (A S P) * S L O$ & 0 & 0 & -.21656 & 0 & -.15794 & 0 & -.16952 & 0 & 0 & -.56659 \\
\hline $4 \operatorname{SIN}(A S P){ }^{\star} S L O$ & 0 & 0 & .03283 & 0 & -.21290 & 0 & .04787 & 0 & 0 & .24004 \\
\hline 5 SLO & 0 & 0 & -.49383 & 0 & -.09355 & 0 & -.20352 & 0 & 0 & .76533 \\
\hline 6 ELEV & 0 & 0 & -.03714 & 0 & 0 & 0 & .03880 & 0 & 0 & -.01515 \\
\hline 7 ELEV $^{2}$ & 0 & 0 & .00026 & 0 & 0 & 0 & -.00055 & 0 & 0 & 0 \\
\hline $8 \ln (E L E V)$ & -.61898 & 0 & 0 & 0 & 0 & 0 & 0 & 0 & 0 & 0 \\
\hline 9 BAA & -.00549 & -.00463 & -.00848 & -.00298 & -.00370 & -.00323 & -.00421 & -.00325 & -.00434 & -.00305 \\
\hline $10 \ln$ (TPSP) & .07678 & .08910 & .13010 & .07743 & .13622 & 0 & .19073 & .15078 & .16980 & .16188 \\
\hline 11 'NONE & 0 & 0 & 0 & 0 & 0 & 0 & 0 & 0 & 0 & 0 \\
\hline $12 \mathrm{MECH}$ & .20702 & 0 & .12941 & .11501 & .08694 & 0 & -.09217 & 0 & 0 & -.12496 \\
\hline 13 BURN & .22443 & 0 & .04401 & .30555 & .25036 & 0 & .03063 & 0 & 0 & .02469 \\
\hline 14 ROAD & .14508 & 0 & .12617 & .08946 & .13741 & 0 & -.12040 & 0 & 0 & .15949 \\
\hline 15 BWAF & 0 & 0 & .01327 & 0 & 0 & 0 & 0 & 0 & 0 & 0 \\
\hline 16 BOTTOM & 0 & 0 & .36066 & 0 & -.29274 & 0 & -.07201 & 0 & 0 & 0 \\
\hline 17 LOWER & 0 & 0 & .20156 & 0 & -.20692 & 0 & -.15738 & 0 & 0 & 0 \\
\hline 18 MIDSLOPE & 0 & 0 & .30022 & 0 & -.10117 & 0 & -.11644 & 0 & 0 & 0 \\
\hline 19 UPPER & 0 & 0 & .34617 & 0 & -.24640 & 0 & -.13008 & 0 & 0 & 0 \\
\hline $20^{\prime}$ RIDGE & 0 & 0 & 0 & 0 & 0 & 0 & 0 & 0 & 0 & 0 \\
\hline \multicolumn{11}{|l|}{ Habitat type groups } \\
\hline $21{ }^{2}$ Dry PSME & 0 & -.00159 & -.07687 & No data & .01435 & No data & No data & No data & No data & No data \\
\hline 22 Moist PSME & 0 & .01830 & -.19234 & No data & -.19420 & No data & No data & No data & No data & No data \\
\hline 23 ABGR & 0 & .10002 & .02146 & .22231 & .21870 & 0 & 0 & No data & No data & No data \\
\hline 24 THPL/TSHE & 0 & .29961 & -.05622 & .26018 & .40546 & 0 & 0 & 0 & No data & 0 \\
\hline 25 'ABLA & 0 & 0 & 0 & 0 & 0 & 0 & 0 & No data & 0 & No data \\
\hline F-ratio & 149.59 & 78.08 & 57.24 & 128.43 & 92.98 & 159.00 & 212.47 & 180.03 & 127.53 & 41.94 \\
\hline R-square & 0.6116 & 0.4922 & 0.5719 & 0.6282 & 0.4943 & 0.4739 & 0.5021 & 0.6102 & 0.4272 & 0.4802 \\
\hline No. trees & 673 & 572 & 878 & 617 & 1,635 & 356 & 3,177 & 349 & 517 & 465 \\
\hline Optimum aspect & NS & NS & $171^{\circ}$ & NS & $233^{\circ}$ & NS & $164^{\circ}$ & NS & NS & $157^{\circ}$ \\
\hline${ }^{4}$ Amplitude & - & - & 1.14 & - & 1.17 & - & 1.11 & - & - & 1.45 \\
\hline
\end{tabular}

'Represented as part of the constant term to avoid a singular matrix.

'Dry Pseudotsuga menziesii (habitat type group 1).

${ }^{3}$ Moist Pseudotsuga menziesii (habitat type groups 2, 3, and 4).

'Height at the optimum aspect divided by height at the poorest aspect. 
Table 19-Weibull distribution functions for determining heights of excess trees. The form of the equation is $H T=B[-\ln (1-X)]^{1 / C}+1$. " $X$ " is a random number drawn from a uniformly distributed pseudorandom number generator

\begin{tabular}{|c|c|c|c|}
\hline \multirow[b]{2}{*}{ Species } & \multicolumn{3}{|c|}{ Years since last disturbance } \\
\hline & $2.7 \mathrm{yr}$ & $8-12 \mathrm{yr}$ & $13+y r$ \\
\hline $\begin{array}{l}\text { Ponderosa } \\
\text { pine }\end{array}$ & $\begin{array}{l}B=2.77922 \\
C=.89932\end{array}$ & $\begin{array}{l}9.03331 \\
1.07493\end{array}$ & $\begin{array}{r}14.13121 \\
.93070\end{array}$ \\
\hline $\begin{array}{l}\text { Western } \\
\text { larch }\end{array}$ & $\begin{array}{l}B=6.64373 \\
C=.90291\end{array}$ & $\begin{array}{r}11.42298 \\
1.16616\end{array}$ & $\begin{array}{r}19.61887 \\
1.30638\end{array}$ \\
\hline $\begin{array}{l}\text { Lodgepole } \\
\text { pine }\end{array}$ & $\begin{array}{l}B=7.36042 \\
C=1.14808\end{array}$ & $\begin{array}{r}10.92885 \\
1.23233\end{array}$ & $\begin{array}{r}25.21441 \\
1.11702\end{array}$ \\
\hline $\begin{array}{l}\text { Engelmann } \\
\text { spruce }\end{array}$ & $\begin{array}{l}B=1.46615 \\
C=.72253\end{array}$ & $\begin{array}{r}5.15927 \\
.73903\end{array}$ & $\begin{array}{l}9.27278 \\
1.12551\end{array}$ \\
\hline $\begin{array}{l}\text { Douglas- } \\
\text { fir }\end{array}$ & $\begin{array}{l}B=3.81608 \\
C=.99673\end{array}$ & $\begin{array}{r}8.16147 \\
.84541\end{array}$ & $\begin{array}{r}10.98770 \\
.94804\end{array}$ \\
\hline $\begin{array}{l}\text { White } \\
\text { pine }\end{array}$ & $\begin{array}{l}B=2.12146 \\
C=.74585\end{array}$ & $\begin{array}{r}5.06040 \\
.78217\end{array}$ & $\begin{array}{r}5.97955 \\
.84217\end{array}$ \\
\hline $\begin{array}{l}\text { Grand } \\
\text { fir }\end{array}$ & $\begin{array}{l}B=3.08957 \\
C=.80068\end{array}$ & $\begin{array}{r}5.83018 \\
.83228\end{array}$ & $\begin{array}{r}10.10575 \\
.95408\end{array}$ \\
\hline $\begin{array}{l}\text { Western } \\
\text { hemlock }\end{array}$ & $\begin{array}{l}B=3.34771 \\
C=.56777\end{array}$ & $\begin{array}{r}6.80682 \\
.89463\end{array}$ & $\begin{array}{r}13.55346 \\
1.21404\end{array}$ \\
\hline $\begin{array}{l}\text { Subalpine } \\
\text { fir }\end{array}$ & $\begin{array}{l}B=2.92136 \\
C=.88514\end{array}$ & $\begin{array}{r}4.58138 \\
.87156\end{array}$ & $\begin{array}{r}10.33328 \\
1.04376\end{array}$ \\
\hline $\begin{array}{l}\text { Western } \\
\text { redcedar }\end{array}$ & $\begin{array}{l}B=3.16951 \\
C=.64055\end{array}$ & $\begin{array}{r}4.50640 \\
.81354\end{array}$ & $\begin{array}{r}8.94054 \\
.94349\end{array}$ \\
\hline
\end{tabular}

Table 20-Equations predicting the probability of site preparations. Only stands that were not deliberately site prepared were used in these analyses. The form of the equation is $P=\left(1+e^{-\left(\Sigma \beta_{i} X_{i}\right)}\right)^{-1}$

\begin{tabular}{lcrr}
\hline \multicolumn{1}{c}{$\begin{array}{c}\text { Variable } \\
(X)\end{array}$} & $\begin{array}{c}\text { Mechanical } \\
(\beta)\end{array}$ & \multicolumn{1}{c}{$\begin{array}{c}\text { Burn } \\
(\beta)\end{array}$} & \multicolumn{1}{c}{$\begin{array}{c}\text { None } \\
(\beta)\end{array}$} \\
\hline 1 Constant & -1.85203 & -15.19530 & 1.04315 \\
2 COS(ASP)*SLO & .49267 & .05195 & -.22095 \\
3 SIN(ASP)*SLO & .19202 & -.61358 & .36958 \\
4 SLO & -.96667 & -.08902 & .76911 \\
5 In(BAA) & -.08592 & -.37792 & .26018 \\
6 ELEV & .02494 & .53037 & -.02969 \\
7 ELEV & 0 & -.00491 & 0 \\
Habitat type series & & & \\
8 'PSME & 0 & & \\
9 ABGR & -.22684 & .08709 & .08573 \\
10 THPL & -.60584 & -.09800 & .15116 \\
11 TSHE & -.83269 & -.75666 & .68076 \\
12 ABLA & -.30560 & -.26382 & .20339 \\
Chi-square & 11.79 & 30.11 & 14.51 \\
Error mean square & 0.9926 & 1.1297 & 1.0019 \\
Percent occurrence & 18.66 & 9.40 & 66.00 \\
No. plots & 6.024 & 6,024 & 6,024 \\
Optimum aspect & $21^{\circ}$ & $275^{\circ}$ & $121^{\circ}$ \\
Amplitude & 0.08 & 0.09 & 0.06 \\
\hline
\end{tabular}

${ }^{1}$ Represented as part of the constant term to avoid a singular matrix. 


Ferguson, Dennis E.; Carlson, Clinton E. 1993. Predicting regeneration establishment with the Prognosis Model. Res. Pap. INT-467. Ogden, UT: U.S. Department of Agriculture, Forest Service, Intermountain Research Station. 54 p.

Conifer establishment following regeneration timber harvests is predicted by version 2 of the Regeneration Establishment Model, a submodel of the Prognosis Model. The regeneration model covers 10 species for forests in Montana, central Idaho, and northern Idaho. Most harvest and site preparation methods can be simulated so that alternative treatments can be evaluated. Also included in the model is the influence of western spruce budworm (Choristoneura occidentalis) on regeneration success. The model predicts the probability of stocking, seedling density, species composition, and seedling heights 2 to 20 years after harvest. This paper describes the study design, equation development, model formulation, and model behavior for the Regeneration Establishment Model.

KEYWORDS: forest succession, forest planning, western spruce budworm, Choristoneura occidentalis, conifers, Montana, Idaho 


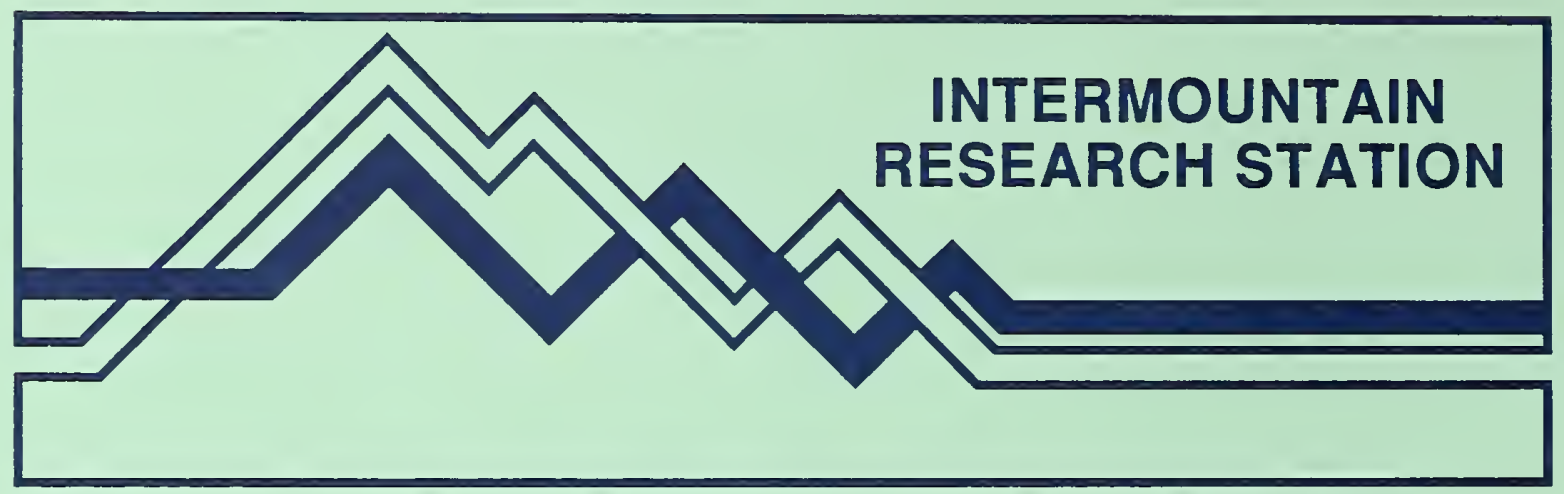

The Intermountain Research Station provides scientific knowledge and technology to improve management, protection, and use of the forests and rangelands of the Intermountain West. Research is designed to meet the needs of National Forest managers, Federal and State agencies, industry, academic institutions, public and private organizations, and individuals. Results of research are made available through publications, symposia, workshops, training sessions, and personal contacts.

The Intermountain Research Station territory includes Montana, Idaho, Utah, Nevada, and western Wyoming. Eighty-five percent of the lands in the Station area, about 231 million acres, are classified as forest or rangeland. They include grasslands, deserts, shrublands, alpine areas, and forests. They provide fiber for forest industries, minerals and fossil fuels for energy and industrial development, water for domestic and industrial consumption, forage for livestock and wildlife, and recreation opportunities for millions of visitors.

Several Station units conduct research in additional western States, or have missions that are national or international in scope.

Station laboratories are located in:

Boise, Idaho

Bozeman, Montana (in cooperation with Montana State University)

Logan, Utah (in cooperation with Utah State University)

Missoula, Montana (in cooperation with the University of Montana)

Moscow, Idaho (in cooperation with the University of Idaho)

Ogden, Utah

Provo, Utah (in cooperation with Brigham Young University)

Reno, Nevada (in cooperation with the University of Nevada)

The policy of the United States Department of Agriculture Forest Service prohibits discrimination on the basis of race, color, national origin, age, religion, sex, or disability, familial status, or political affiliation. Persons believing they have been discriminated against in any Forest Service related activity should write to: Chief, Forest Service, USDA, P.O. Box 96090, Washington, DC 20090-6090. 